NBER WORKING PAPER SERIES

\title{
STRATEGIC TRADE POLICY WITH ENDOGENOUS CHOICE OF QUALITY AND ASYMMETRIC COSTS
}

\author{
Dongsheng Zhou \\ Barbara J. Spencer \\ Ilan Vertinsky \\ Working Paper 7536 \\ http:/www.nber.org/papers/w7536 \\ NATIONAL BUREAU OF ECONOMIC RESEARCH \\ 1050 Massachusetts Avenue \\ Cambridge Ma 02138 \\ February 2000
}

We are grateful to Zhiqi Chen for very helpful ideas, discussions and comments. We would also like to acknowledge useful suggestions received from Professors James Brander and Shelby Brumelle. Financial support was provided by the SSHRC and NSERC. This paper is part of NBER's research program in International Trade and Investment. The views expressed herein are those of the authors and not necessarily those of the National Bureau of Economic Research.

(C) 2000 by Dongsheng Zhou, Barbara J. Spencer and Ilan Vertinsky. All rights reserved. Short sections of text, not to exceed two paragraphs, may be quoted without explicit permission provided that full credit, including (C) notice, is given to the source. 
Strategic Trade Policy with Endogenous Choice of Quality and Asymmetric Costs.

Dongsheng Zhou, Barbara J. Spencer and Ilan Vertinsky

NBER Working Paper No. 7536

February 2000

JEL No. F12, F13

$\underline{\text { ABSTRACT }}$

This paper examines the strategic trade policy incentives for investment policies towards quality improvements in a vertically differentiated exporting industry. Firms first compete in qualities and then export to a third country market based on Bertrand or Cournot competition. Optimal policies are asymmetric across the two producing countries. Under Bertrand competition, the low-quality country subsidizes investment to raise export quality, while the high-quality country imposes a tax so as to reduce the quality of its already high quality exports. Under Cournot competition, the results are reversed with a tax in the low-quality country and a subsidy in the highquality country.

Dongsheng Zhou

Faculty of Business

City University of Hong Kong

83 Tat Chee Avenue, Kowloon

Hong Kong

mkdszhou@cityu.edu.hk
Barbara J. Spencer

Faculty of Commerce

University of British Columbia

2053 Main Mall, Vancouver

B.C. V6T1Z2, Canada

and NBER

barbara.spencer@commerce.ubc.ca

Ilan Vertinsky,

Fepa Research Unit, Forest Science Centre

University of British Columbia

2424 Main Mall

Vancouver B.C. V6T 1 Z4

fepa@interchange.ubc.ca 


\section{Strategic Trade Policy with Endogenous Choice of Quality and Asymmetric Costs}

\section{Introduction}

The availability of a greater variety of products with increasing levels of world trade has emphasised the importance of non-price competition for success in exporting. At one extreme, there is Japan with its demanding consumers and quality oriented production culture and, at the other, there is the emergence of lower quality, but cost competitive producers among the newly industrialized countries (NICs). Thus success for a company can often involve the careful positioning of products in the quality spectrum taking into account the qualities chosen by foreign rivals. The importance of this strategy is particularly evident in the rapidly expanding, knowledge intensive industries, such as pharmaceuticals and computer software. First, these industries often exhibit high up-front costs of product development with subsequent low variable costs of production. Also, firms tend to be oligopolistic because of limitations on entry due to this cost structure and an ability to patent. In such an environment, the particular features that differentiate products are the main determinants of success ${ }^{1}$ and a major focus of competition is at the product development stage.

There are a number of possible motives for government policy targeted at product quality. In particular, regulations affecting quality, such as minimum quality standards, may simply be a response to the need for consumer protection due to asymmetric information about product quality. Such policies may also be a means to protect domestic industry from import competition ${ }^{2}$. Other motives, however, are needed to explain the existence of policies targeted at the quality of exports ${ }^{3}$.

\footnotetext{
${ }^{1}$ These features can be broadly interpreted as any attributes, including attributes of the production process (e.g. impacts of production on the environment) that consumers care about (see Inglehart 1990).

${ }^{2}$ For example, the U.S. has long complained that Japanese regulations specifying detailed characteristics that particular products must satisfy is discriminatory against imports.

${ }^{3}$ Quality upgrading of exports could be an indirect consequence of growth policies that generally target investment and R\&D. Our concern is with policies that specifically target the quality of exports.
} 
Taiwan, for example, has a long standing policy to influence the quality of exports through compulsory inspection of certain export items and the subsidization of quality control associations in some sectors [e.g., machine tools, heavy electrical machinery, umbrellas and toys] (Wade 1990:144]). Korea has also encouraged product quality improvement in some sectors, while, as part of the so called "Northern strategy", it has also subsidized the marketing of certain low quality products, thus eliminating incentives to improve product quality (Ursacki and Vertinsky 1994). In Finland, the government subsidized product oriented R\&D in paper production, offering incentives for climbing the product quality scale in an industry which was already a world leader in the production of high quality papers (Wilson et al. 1998). Subsidies for product quality improvement in the newsprint industry have also been recommended in Canada, despite Canadian leadership in quality (see Binkley 1993).

There are various arguments as to why governments might want to raise the quality of exports when quality levels are low. For example, Taiwan may have imposed quality controls to avoid damage to the reputation of all its exports from the export of shoddy goods. There may also be a motive to improve the quality of exports so as to satisfy minimum quality standards in importing countries. However, these arguments do not explain why governments would subsidize quality improvements for firms that are already industry leaders in quality or even discourage the development of quality for their low quality exporters.

This paper explores the implications of a "strategic-trade policy" or "rent-shifting" motive 4 for subsidy or tax policy applied to investments in quality improvements for exported products. There are two countries, a developed country and an LDC (lesser developed country), each with one firm producing a quality differentiated good. To focus on strategic trade policy effects, we assume

\footnotetext{
${ }^{4}$ For the original work, see Spencer and Brander (1983) and Brander and Spencer (1985). Eaton and Grossman (1986) show the importance of Bertrand versus Cournot competition.
} 
that the entire production is exported to a third country market on the basis of either Bertrand or Cournot competition. A feature of the model is asymmetry of investment costs. Thus to reflect the disparity in investment opportunities between the LDC and developed country, we assume the LDC faces an equal or lower productivity of investment in quality than the developed country ${ }^{5}$. If this cost difference is sufficiently large, we are able to show that there exists a unique pure strategy equilibrium in which the LDC exports the low quality product and the developed country the high quality product. However, even if countries are identical as to investment costs, the two countries will produce different qualities of products and have an incentive to pursue asymmetric policies towards the quality of their exports. As we show, under Bertrand price competition, the low quality producer has an incentive to subsidize investment in quality, whereas optimal policy by the highquality producer involves an investment tax. These policies are reversed under Cournot competition with optimal policy involving a tax by the low quality producer and a subsidy by the high-quality producer. Thus strategic-trade policy can explain why a country might intervene to raise the quality of low quality exports, but it also shows that there are circumstances in which there is a motive for less obvious policies, such as a subsidy to a high-quality producer or a tax on quality development by a low-quality producer.

The model structure follows Spencer and Brander (1983), except that government policy affects positioning in product space, rather than levels of cost-reducing investment (in R\&D) for products that are fixed in nature ${ }^{6}$. Thus there is a three stage (full information) game in which governments act first to maximize domestic welfare by committing to their subsidy or tax policy. If both countries intervene, there is a Nash equilibrium in subsidy and tax levels. Firms then commit

${ }^{5}$ For the effects of asymmetric production costs see De Meza (1986) and Neary (1994).

${ }^{6}$ Policy is very different since, for the basic model, it involves an R\&D subsidy under both Bertrand and Cournot competition (see Bagwell and Staiger 1994). 
to their levels of investment in quality and subsequently compete (in quantities or prices). As in Spencer and Brander (1983), the advantages of unilateral tax or subsidy policy to the domestic country accrue from their ability to move the outcome from the Nash equilibrium in quality space to what would have been the Stackelberg equilibrium with the domestic firm as leader and foreign rival as the follower. Thus the policy works by influencing those actions of the rival firm that are taken as given by the domestic firm at the Nash equilibrium.

We also explore the implications of coordinated policy choices by the two producing nations so as to maximize their joint welfare. With the elimination of the motive for rent-extraction from the rival firm, this focuses policy towards exploiting consumers in the third country market. Nevertheless, the implications of this for policies towards quality are not immediately obvious. For Bertrand competition, a move from the Nash policies to the jointly optimal policies causes a switch in policies for both countries, namely the LDC should tax rather than subsidize quality and the developed country should subsidize rather than tax quality. Under Cournot competition, the jointly optimal policy is a tax on investment in quality by both countries.

Our assumption that the costs of quality development are sunk before the market determination of prices and output is well established in the literature (see for example, Gabszewicz and Thisse 1979, Shaked and Sutton 1982, 1983, Ronen 1991 and Motta 1993). However, international trade theory has mostly concentrated on an alternative model, in which quality is chosen simultaneously with price or output ${ }^{7}$ (see, for example, Krishna (1987) and Das and Donnenfield (1987, 1989), Ries (993) but Herguera, Kujal and Petrakis (1999) is an exception). Also, the focus of this international literature (including the above papers) differs from ours because of its main

\footnotetext{
${ }^{7}$ Since quality affects marginal production costs, this simultaneous choice model is sometimes referred to as a "variable cost of quality model". Similarly, since the cost of quality is fixed when prices and output are determined, the sunk cost model has been referred to as a "fixed cost of quality model".
} 
concern with the effects of domestic import restrictions, particularly the implications with respect to quality upgrading or downgrading ${ }^{8}$.

In addition to the strategic trade policy results, the paper also contributes to the technical development of the quality differentiation model. First, as previously mentioned, we introduce asymmetric costs of development of quality and show existence and uniqueness of equilibrium for a sufficiently large cost difference under both Bertrand and Cournot competition. We also provide analytical proofs of concavity of profit and welfare functions with respect to quality, both for asymmetric costs of investment and for a wider class of investment cost functions than has previously been considered in the literature. Particularly for the Cournot case, numerical equilibrium values have previously been used to help establish concavity (see Motta (1993) and Herguera, Kujal and Petrakis (1999)).

The paper is organized as follows: Section 2 sets out the structure of the game and the basic consumer preferences and costs underlying the model of quality choice. Section 3 investigates investment policy and quality choice under Bertrand competition whereas Section 4 develops and contrasts the results for Cournot competition. Finally, section 5 contains concluding remarks.

\section{The basic model: consumer demand and costs}

There are two firms, firm 1 located in an LDC (lesser developed country) and firm 2, in a developed country. Each firm produces a quality differentiated product, all of which is exported to a third country market. The game between firms involves a sub-game perfect equilibrium with two stages of decision. In stage 1 , the quality of each product is determined at a Nash equilibrium in which each firm chooses its investment in quality so as to maximize profit taking the quality of the other firm as given. In stage 2, the products are sold on the basis of a Bertrand-Nash equilibrium if

${ }^{8}$ Feenstra (1988) discusses these two approaches and provides evidence on quality upgrading. 
price is the decision variable or a Cournot-Nash equilibrium if quantity is the decision variable. This two-stage structure reflects the idea that price (or quantity) can be changed more easily than product quality, which is a longer term decision. For simplicity we assume that marginal production costs are constant and, without loss of generality, we let these costs be zero. Governments commit to policy towards investment at stage 0 , prior to the game played by firms.

The asymmetry in investment costs across countries is reflected by the assumption that firm 2 in the developed country requires an investment $\mathrm{F}(\mathrm{q})$ to produce a product with quality $\mathrm{q}$, whereas firm 1, in the LDC requires an investment of $\gamma \mathrm{F}(\mathrm{q})$ where $\gamma \geq 1$. Otherwise, the two firms are identical for any given value of q. Following Ronnen (1991), we assume F(q) satisfies

$$
\begin{aligned}
\mathrm{F}(0)= & \mathrm{F}^{\prime}(0)=0 ; \mathrm{F}^{\prime}(\mathrm{q})>0, \mathrm{~F}^{\prime \prime}(\mathrm{q})>0 \text { for } \mathrm{q}>0 \text { and } \\
& \lim _{q \rightarrow \infty} \mathrm{F}^{\prime}(\mathrm{q})=\infty ; \mathrm{F}^{\prime \prime \prime}(\mathrm{q}) \geq 0 .
\end{aligned}
$$

Thus the investment cost, $\mathrm{F}(\mathrm{q})$, and marginal investment $\operatorname{cost} \mathrm{F}^{\prime}(\mathrm{q})$ are strictly increasing in quality for all $\mathrm{q} \in(0, \propto]$. Since $\mathrm{F}^{\prime \prime}(\mathrm{q})>0$ and $\mathrm{F}^{\prime \prime \prime}(\mathrm{q}) \geq 0, \mathrm{~F}(\mathrm{q})$ is strictly convex and $\mathrm{F}^{\prime}(\mathrm{q})$ is linear or convex. The assumptions $\mathrm{F}(0)$ and $\mathrm{F}^{\prime}(0)$ help ensure that both firms enter. Two classes of functions satisfying these restrictions ${ }^{9}$ are $\mathrm{F}(\mathrm{q})=\mathrm{aq}^{\mathrm{n}}$ for $\mathrm{n} \geq 2$ and $\mathrm{F}(\mathrm{q})=\mathrm{q}\left(\mathrm{e}^{\mathrm{aq}}-1\right)$ where $\mathrm{a}>0$.

We use a standard model of quality differentiation (see, for example, Gabszewicz and Thisse 1979, Bond 1988, Das and Donnenfeld 1987, 1989, Tirole 1988 and Motta 1993) in which consumers purchase at most one unit of the differentiated product. Other things being equal, all consumers prefer a higher quality product. Letting $\theta$ represent a taste parameter for quality, there is a continuum of consumers indexed by $\theta$, which is uniformly distributed on $[0,1]$. Consumers obtain

\footnotetext{
${ }^{9}$ If $\mathrm{F}(\mathrm{q})=\mathrm{aq}^{\mathrm{n}}$ for $\mathrm{n} \geq 2$, then $\mathrm{F}^{\prime}(\mathrm{q})=\operatorname{naq}^{\mathrm{n}-1}>0$ and $\mathrm{F}^{\prime \prime}(\mathrm{q})=\mathrm{n}(\mathrm{n}-1) \mathrm{aq}^{\mathrm{n}-2}>0$ for $\mathrm{q}>0$ and $\mathrm{F}^{\prime \prime \prime}(\mathrm{q}) \geq 0$. If $\mathrm{F}(\mathrm{q})$ $=\mathrm{q}\left(\mathrm{e}^{\mathrm{aq}}-1\right)$, then $\mathrm{F}^{\prime}(\mathrm{q})=(1+\mathrm{aq}) \mathrm{e}^{\mathrm{aq}}-1>0, \mathrm{~F}^{\prime \prime}(\mathrm{q})=\mathrm{a}(2+\mathrm{aq}) \mathrm{e}^{\mathrm{aq}}>0$ and $\mathrm{F}^{\prime \prime \prime}(\mathrm{q})=(\mathrm{a})^{2}(3+\mathrm{aq}) \mathrm{e}^{\mathrm{aq}}>0$ for $\mathrm{q}>0$. In both cases, $\mathrm{F}(0)=0$ and $\mathrm{F}^{\prime}(0)=0$.
} 
$\mathrm{a}$ (linear) utility ${ }^{10}, \theta \mathrm{q}$, from consumption of a good with quality q and price $\mathrm{P}$. Letting $\mathrm{p} \equiv \mathrm{P} / \mathrm{q}$ for $q>0$, we also adjust the price $P$ to reflect differences in quality. This implies a consumer surplus for taste $\theta$ given by:

$$
\mathrm{C}^{\mathrm{s}}=\mathrm{C}^{\mathrm{s}}(\mathrm{q}, \mathrm{p} ; \theta)=\theta \mathrm{q}-\mathrm{P}=\mathrm{q}(\theta-\mathrm{p}) \text { for } \mathrm{q}>0 .
$$

Assuming a reservation surplus of zero, consumers purchase the product only if $\mathrm{C}^{\mathrm{s}}>0$, which requires $q>0$. Also since $\theta \in[0,1]$, for any $p>0$, there is a range of consumers who choose not to buy the good.

The two firms are free to produce the same or different qualities. Referring to the low and high quality firms as firms $\mathrm{L}$ and $\mathrm{H}$ respectively, although we will subsequently identify firm $\mathrm{L}$ as located in the LDC and firm $\mathrm{H}$ as in the developed country (see Proposition 1 for the Bertrand case and Proposition 9 for the Cournot case), for the moment we do not specify which of the firms, L or $\mathrm{H}$, is firm 1 or 2 . Using the superscripts $\mathrm{L}$ and $\mathrm{H}$ to indicate variables associated with firms $\mathrm{L}$ and $\mathrm{H}$ respectively, then the quality-adjusted price is given by $\mathrm{p}^{\mathrm{L}}=\mathrm{P}^{\mathrm{L}} / \mathrm{q}^{\mathrm{L}}$ for the low quality product and $\mathrm{p}^{\mathrm{H}}=\mathrm{P}^{\mathrm{H}} / \mathrm{q}^{\mathrm{H}}$ for the high quality product where $\mathrm{q}^{\mathrm{L}} \leq \mathrm{q}^{\mathrm{H}}$. We also define $\mathrm{r} \equiv \mathrm{q}^{\mathrm{H}} / \mathrm{q}^{\mathrm{L}} \geq 1$ to represent the ratio of high to low quality.

If $\mathrm{q}^{\mathrm{L}}=\mathrm{q}^{\mathrm{H}}$, then both firms can remain in the market only if $\mathrm{p}^{\mathrm{L}}=\mathrm{p}^{\mathrm{H}}$. Since consumers would buy the product for $\theta \in(p, 1]$, letting $\mathrm{x}^{\mathrm{L}}$ and $\mathrm{x}^{\mathrm{H}}$ represent the quantities purchased of qualities $\mathrm{q}^{\mathrm{L}}$ and $\mathrm{q}^{\mathrm{H}}$ respectively, this implies an inverse demand,

$$
\mathrm{P}^{\mathrm{i}}=\left(1-\left(\mathrm{x}^{\mathrm{L}}+\mathrm{x}^{\mathrm{H}}\right)\right) \mathrm{q}^{\mathrm{i}} \text { for } \mathrm{q}^{\mathrm{L}}=\mathrm{q}^{\mathrm{H}} \text { and } \mathrm{i}=\mathrm{L}, \mathrm{H} .
$$

However, similar to Motta (1993), we will show that in equilibrium, qualities differ across firms for Cournot as well as Bertrand competition. For $\mathrm{q}^{\mathrm{L}}<\mathrm{q}^{\mathrm{H}}$, let $\theta=\tilde{\theta}$ represent the value of the taste

\footnotetext{
${ }^{10}$ The results can be generalized to any concave utility function $u(q)$, where $u^{\prime}(q)>0, u(q) \leq 0$. There are no income effects since, implicitly, utility is assumed to be separable in a second homogeneous good. This homogeneous good also acts behind the scenes to achieve trade balance.
} 
parameter at which a consumer would purchase the differentiated good but is indifferent between the high and low quality. Then, setting $\mathrm{C}^{\mathrm{s}}\left(\mathrm{q}^{\mathrm{L}}, \mathrm{p}^{\mathrm{L}} ; \tilde{\boldsymbol{\theta}}\right)=\mathrm{C}^{\mathrm{s}}\left(\mathrm{q}^{\mathrm{H}}, \mathrm{p}^{\mathrm{H}} ; \tilde{\boldsymbol{\theta}}\right)$ from (2), it follows using $\mathrm{r}>1$, that:

$$
\tilde{\boldsymbol{\theta}}=\left(\mathrm{P}^{\mathrm{H}}-\mathrm{P}^{\mathrm{L}}\right) /\left(\mathrm{q}^{\mathrm{H}}-\mathrm{q}^{\mathrm{L}}\right)=\left(\mathrm{rp} \mathrm{p}^{\mathrm{H}}-\mathrm{p}^{\mathrm{L}}\right) /(\mathrm{r}-1) .
$$

The requirement $\mathrm{C}^{\mathrm{s}}\left(\mathrm{q}^{\mathrm{H}}, \mathrm{p}^{\mathrm{H}} ; \tilde{\theta}\right)>0$ implies $\tilde{\theta}>\mathrm{p}^{\mathrm{H}}$, and hence consumers with taste $\theta \in(\tilde{\theta}, 1]$ buy quality $\mathrm{q}^{\mathrm{H}}$. Also, since $\mathrm{C}^{\mathrm{s}}\left(\mathrm{q}^{\mathrm{L}}, \mathrm{p}^{\mathrm{L}} ; \theta\right)=\mathrm{q}^{\mathrm{L}}\left(\theta-\mathrm{p}^{\mathrm{L}}\right)>0$ for $\theta>\mathrm{p}^{\mathrm{L}}$ and since $\tilde{\theta}>\mathrm{p}^{\mathrm{H}}$ implies $\tilde{\theta}>\mathrm{p}^{\mathrm{H}}>\mathrm{p}^{\mathrm{L}}$ (from (4)), there exists a range of taste parameters $\theta \in\left(\mathrm{p}^{\mathrm{L}}, \tilde{\theta}\right]$ for which consumers will buy quality $q^{L}$. Consumers for whom $\theta \in\left[0, p^{\mathrm{L}}\right]$ do not purchase the quality differentiated good. Since each consumer buys one or no units of the good, the respective demand functions for the low and high quality products are given by

$$
\mathrm{x}^{\mathrm{L}}=\tilde{\boldsymbol{\theta}}-\mathrm{p}^{\mathrm{L}}=\mathrm{r}\left(\mathrm{p}^{\mathrm{H}}-\mathrm{p}^{\mathrm{L}}\right) /(\mathrm{r}-1) \text { and } \mathrm{x}^{\mathrm{H}}=1-\tilde{\boldsymbol{\theta}}=1-\left(\mathrm{rp}^{\mathrm{H}}-\mathrm{p}^{\mathrm{L}}\right) /(\mathrm{r}-1) .
$$

\section{Investment policy and quality choice under Bertrand competition}

Assuming Bertrand price competition at the second stage, the two-stage model of firm behavior involving choice of quality and then sale of the good is developed in subsection 3.1. Policies towards investment in quality are then investigated in 3.2 and 3.3 for the LDC and developed country respectively.

\subsection{The two-stage model of firm behavior: Bertrand competition.}

As is standard in these models, we start by examining price determination at the second stage Bertrand equilibrium before considering the first stage choice of quality. Since marginal production cost is assumed to be zero, firms $\mathrm{L}$ and $\mathrm{H}$ earn profits from production equal to their respective revenues, given by $\mathrm{R}^{\mathrm{L}}=\mathrm{P}^{\mathrm{L}} \mathrm{x}^{\mathrm{L}}$ and $\mathrm{R}^{\mathrm{H}}=\mathrm{P}^{\mathrm{H}} \mathrm{x}^{\mathrm{H}}$. Thus at stage 2 , each firm sets its price to maximize its revenue, taking the price of the other firm as given. Since the qualities $\mathrm{q}^{\mathrm{L}}$ and $\mathrm{q}^{\mathrm{H}}$ are committed at the first stage, this is equivalent to choosing quality-adjusted prices, $\mathrm{p}^{\mathrm{L}}=\mathrm{P}^{\mathrm{L}} / \mathrm{q}^{\mathrm{L}}$ for firm $\mathrm{L}$ and $\mathrm{p}^{\mathrm{H}}$ 
$=\mathrm{P}^{\mathrm{H}} / \mathrm{q}^{\mathrm{H}}$ for firm $\mathrm{H}$. Expressing $\mathrm{R}^{\mathrm{L}}=\mathrm{q}^{\mathrm{L}} \mathrm{p}^{\mathrm{L}}\left(\tilde{\theta}-\mathrm{p}^{\mathrm{L}}\right)$ and $\mathrm{R}^{\mathrm{H}}=\mathrm{q}^{\mathrm{H}} \mathrm{p}^{\mathrm{H}}(1-\tilde{\theta})($ from (4) and (5)) and using $\partial \tilde{\boldsymbol{\theta}} / \partial \mathrm{p}^{\mathrm{L}}=-1 /(\mathrm{r}-1)$ and $\partial \tilde{\boldsymbol{\theta}} / \partial \mathrm{p}^{\mathrm{H}}=\mathrm{r} /(\mathrm{r}-1)$, it follows that $\mathrm{p}^{\mathrm{L}}$ and $\mathrm{p}^{\mathrm{H}}$ satisfy the first order conditions:

$$
\partial \mathrm{R}^{\mathrm{L}} / \partial \mathrm{p}^{\mathrm{L}}=\mathrm{q}^{\mathrm{H}}\left(\mathrm{p}^{\mathrm{H}}-2 \mathrm{p}^{\mathrm{L}}\right) /(\mathrm{r}-1)=0 ; \partial \mathrm{R}^{\mathrm{H}} / \partial \mathrm{p}^{\mathrm{H}}=\mathrm{q}^{\mathrm{H}}\left[1-\left(2 \mathrm{rp}^{\mathrm{H}}-\mathrm{p}^{\mathrm{L}}\right) /(\mathrm{r}-1)\right]=0,
$$

where the second order and stability conditions are also satisfied ${ }^{11}$. As is typical for Bertrand competition, since $\partial R^{i} / \partial p^{i}$ is increasing in $p^{j}$ for $i, j=L, H$ and $j \neq i$, the products are strategic complements in price space.

Solving the conditions (6), it follows, using (4), that in equilibrium, prices are given by:

$$
\mathrm{p}^{\mathrm{L}}=(\mathrm{r}-1) /(4 \mathrm{r}-1), \mathrm{p}^{\mathrm{H}}=2 \mathrm{p}^{\mathrm{L}} \text { and } \tilde{\theta}=(2 \mathrm{r}-1) /(4 \mathrm{r}-1)
$$

It is notable that firm $\mathrm{H}$ enjoys a demand (as well as a quality-adjusted price) that is twice that of firm L: i.e. from (5) using 1- $\tilde{\theta}=2\left(\tilde{\theta}-\mathrm{p}^{\mathrm{L}}\right)=2 \mathrm{r} /(4 \mathrm{r}-1)$ from (4) and (7),

$$
\mathrm{x}^{\mathrm{L}}=\tilde{\theta}-\mathrm{p}^{\mathrm{L}}=\mathrm{r} /(4 \mathrm{r}-1) \text { and } \mathrm{x}^{\mathrm{H}}=1-\tilde{\theta}=2 \mathrm{x}^{\mathrm{L}} .
$$

Letting $\phi(r)=p^{\mathrm{L}} \mathrm{x}^{\mathrm{L}}=\mathrm{p}^{\mathrm{H}} \mathrm{X}^{\mathrm{H}} / 4$, we can express the Bertrand equilibrium revenues of the two firms as $\mathrm{R}^{\mathrm{L}}\left(\mathrm{q}^{\mathrm{L}}, \mathrm{q}^{\mathrm{H}}\right)=\phi(\mathrm{r}) \mathrm{q}^{\mathrm{L}}$ and $\mathrm{R}^{\mathrm{H}}\left(\mathrm{q}^{\mathrm{L}}, \mathrm{q}^{\mathrm{H}}\right)=4 \phi(\mathrm{r}) \mathrm{q}^{\mathrm{H}}$ where from (7) and (8), $\phi(\mathrm{r})=\mathrm{r}(\mathrm{r}-1) /(4 \mathrm{r}-1)^{2}$ and hence

$$
\phi^{\prime}(\mathrm{r})=(2 \mathrm{r}+1) /(4 \mathrm{r}-1)^{3}>0 \text { and } \phi^{\prime \prime}(\mathrm{r})=-2(8 \mathrm{r}+7) /(4 \mathrm{r}-1)^{4}<0 .
$$

It follows that higher quality products tend to command higher revenues, but also (as shown by $\phi^{\prime}(\mathrm{r})$ $>0$ ) each firm's revenue is increased by a greater separation of products. Since in response to an increase in $r$, quality adjusted prices rise and outputs fall for both firms, this latter increase in revenue can be explained by a reduction in price competition: i.e. from (7) and (8),

$$
\mathrm{dp}^{\mathrm{H}} / \mathrm{dr}=2\left(\mathrm{dp}^{\mathrm{L}} / \mathrm{dr}\right)=6 /(4 \mathrm{r}-1)^{2}>0 \text { and } \mathrm{dx}^{\mathrm{H}} / \mathrm{dr}=2(\mathrm{dx} / \mathrm{dr})=-2 /(4 \mathrm{r}-1)^{2}<0 .
$$

Using subscripts $\mathrm{L}$ and $\mathrm{H}$ to represent partial derivatives with respect to $\mathrm{q}^{\mathrm{L}}$ and $\mathrm{q}^{\mathrm{H}}$ respectively, since $\mathrm{r}$ is increasing in $\mathrm{q}^{\mathrm{H}}$ and decreasing in $\mathrm{q}^{\mathrm{L}}$, this implies:

\footnotetext{
${ }^{11}$ We have $\partial^{2} R^{\mathrm{L}} /\left(\partial \mathrm{p}^{\mathrm{L}}\right)^{2}=-2 \mathrm{q}^{\mathrm{H}} /(\mathrm{r}-1)<0, \partial^{2} \mathrm{R}^{\mathrm{H}} /\left(\partial \mathrm{p}^{\mathrm{H}}\right)^{2}=-2 \mathrm{rq}^{\mathrm{H}} /(\mathrm{r}-1)<0$ and using $\partial^{2} \mathrm{R}^{\mathrm{i}} /\left(\partial \mathrm{p}^{\mathrm{L}}\right)\left(\partial \mathrm{p}^{\mathrm{H}}\right)=\mathrm{q}^{\mathrm{H}} /(\mathrm{r}-1)>$ 0 for $\mathrm{i}=\mathrm{L}, \mathrm{H}$, we obtain $\Omega \equiv\left(\partial^{2} \mathrm{R}^{\mathrm{L}} /\left(\partial \mathrm{p}^{\mathrm{L}}\right)^{2}\right)\left(\partial^{2} \mathrm{R}^{\mathrm{H}} /\left(\partial \mathrm{p}^{\mathrm{H}}\right)^{2}\right)-\left(\partial^{2} \mathrm{R}^{\mathrm{i}} /\left(\partial \mathrm{p}^{\mathrm{L}}\right)\left(\partial \mathrm{p}^{\mathrm{H}}\right)\right)^{2}=\left(\mathrm{q}^{\mathrm{H}}\right)^{2}(4 \mathrm{r}-1) /(\mathrm{r}-1)^{2}>0$.
} 


$$
\mathrm{R}_{\mathrm{H}}^{\mathrm{L}}=\phi^{\prime}(\mathrm{r})>0 \text { and } \mathrm{R}_{\mathrm{L}}^{\mathrm{H}}=-4(\mathrm{r})^{2} \phi^{\prime}(\mathrm{r})<0
$$

Turning to the stage 1 determination of quality, we continue to keep the analysis general by letting $\lambda^{\mathrm{L}} \mathrm{F}\left(\mathrm{q}^{\mathrm{L}}\right)$ and $\lambda^{\mathrm{H}} \mathrm{F}\left(\mathrm{q}^{\mathrm{H}}\right)$ represent the cost of investment in quality faced by firm $\mathrm{L}$ and firm $\mathrm{H}$ respectively. In addition to the cost disadvantage, $\gamma$, in the $\mathrm{LDC}$, the parameters, $\lambda^{\mathrm{L}}>0$ and $\lambda^{\mathrm{H}}>$ 0 will subsequently be interpreted as including the effects of subsidies and taxes arising from investment policies in the two countries. Thus, the respective profits of firms $\mathrm{L}$ and $\mathrm{H}$ are given by:

$$
\pi^{\mathrm{L}}\left(\mathrm{q}^{\mathrm{L}}, \mathrm{q}^{\mathrm{H}}\right)=\mathrm{R}^{\mathrm{L}}\left(\mathrm{q}^{\mathrm{L}}, \mathrm{q}^{\mathrm{H}}\right)-\lambda^{\mathrm{L}} \mathrm{F}\left(\mathrm{q}^{\mathrm{L}}\right) \text { and } \pi^{\mathrm{H}}\left(\mathrm{q}^{\mathrm{L}}, \mathrm{q}^{\mathrm{H}}\right)=\mathrm{R}^{\mathrm{H}}\left(\mathrm{q}^{\mathrm{L}}, \mathrm{q}^{\mathrm{H}}\right)-\lambda^{\mathrm{H}} \mathrm{F}\left(\mathrm{q}^{\mathrm{H}}\right)
$$

where $\mathrm{R}^{\mathrm{L}}\left(\mathrm{q}^{\mathrm{L}}, \mathrm{q}^{\mathrm{H}}\right)=\phi(\mathrm{r}) \mathrm{q}^{\mathrm{L}}$ and $\mathrm{R}^{\mathrm{H}}\left(\mathrm{q}^{\mathrm{L}}, \mathrm{q}^{\mathrm{H}}\right)=4 \phi(\mathrm{r}) \mathrm{q}^{\mathrm{H}}$. Setting $\mathrm{q}^{\mathrm{L}}$ to maximize $\pi^{\mathrm{L}}$ taking $\mathrm{q}^{\mathrm{H}}$ as given and setting $\mathrm{q}^{\mathrm{H}}$ to maximize $\pi^{\mathrm{H}}$ taking $\mathrm{q}^{\mathrm{L}}$ as given, it follows from (12) that, at the Nash equilibrium in quality, $\mathrm{q}^{\mathrm{L}}$ and $\mathrm{q}^{\mathrm{H}}$ satisfy the first order conditions:

$$
\pi^{\mathrm{L}}=\mathrm{R}_{\mathrm{L}^{-}}^{\mathrm{L}}-\lambda^{\mathrm{L}} \mathrm{F}^{\prime}\left(\mathrm{q}^{\mathrm{L}}\right)=0 \text { and } \pi_{\mathrm{H}}^{\mathrm{H}}=\mathrm{R}_{\mathrm{H}}^{\mathrm{H}}-\lambda^{\mathrm{H}} \mathrm{F}^{\prime}\left(\mathrm{q}^{\mathrm{H}}\right)=0
$$

where, using (9), we obtain:

$$
\begin{aligned}
& \mathrm{R}_{\mathrm{L}}^{\mathrm{L}}=\phi(\mathrm{r})-\mathrm{r} \phi^{\prime}(\mathrm{r})=(\mathrm{r})^{2}(4 \mathrm{r}-7) /(4 \mathrm{r}-1)^{3}>0 \text { for } \mathrm{r}>7 / 4 \text { and } \\
& \mathrm{R}_{\mathrm{H}}^{\mathrm{H}}=4\left(\phi(\mathrm{r})+\mathrm{r} \phi^{\prime}(\mathrm{r})\right)=4 \mathrm{r}\left(4(\mathrm{r})^{2}-3 \mathrm{r}+2\right) /(4 \mathrm{r}-1)^{3}>0 .
\end{aligned}
$$

The second order conditions are satisfied since, from (13), (14), (9) and $F^{\prime \prime}(q)>0$, we have

$$
\pi_{L L}^{\mathrm{L}}=\mathrm{R}_{\mathrm{LL}}^{\mathrm{L}}-\lambda^{\mathrm{L}} \mathrm{F}^{\prime \prime}\left(\mathrm{q}^{\mathrm{L}}\right)<0 \text { and } \pi_{\mathrm{HH}}^{\mathrm{H}}=\mathrm{R}_{\mathrm{HH}}^{\mathrm{H}}-\lambda^{\mathrm{H}} \mathrm{F}^{\prime \prime}\left(\mathrm{q}^{\mathrm{H}}\right)<0 \text {, }
$$

where $\mathrm{R}_{\mathrm{LL}}^{\mathrm{L}}=(\mathrm{r})^{2} \phi^{\prime \prime}(\mathrm{r}) / \mathrm{q}^{\mathrm{L}}<0$ and $\mathrm{R}_{H H}^{\mathrm{H}}=4\left(2 \phi^{\prime}(\mathrm{r})+\mathrm{r} \phi^{\prime \prime}(\mathrm{r})\right) / \mathrm{q}^{\mathrm{L}}=-8(5 \mathrm{r}+1) / \mathrm{q}^{\mathrm{L}}(4 \mathrm{r}-1)^{4}<0$. Since $\mathrm{R}_{\mathrm{LH}}^{\mathrm{L}}$ $=-r \phi^{\prime \prime}(\mathrm{r}) / \mathrm{q}^{\mathrm{L}}=-\mathrm{R}_{\mathrm{LL}}^{\mathrm{L}} / \mathrm{r}>0$ and $\mathrm{R}_{\mathrm{HL}}^{\mathrm{H}}=-\mathrm{rR}_{\mathrm{HH}}^{\mathrm{H}}>0$, we also obtain $\mathrm{R}_{\mathrm{LL}}^{\mathrm{L}} \mathrm{R}_{\mathrm{HH}}^{\mathrm{H}}-\mathrm{R}_{\mathrm{LH}}^{\mathrm{L}} \mathrm{R}_{\mathrm{HL}}^{\mathrm{H}}=0$ and hence

$$
\mathrm{D} \equiv \pi_{\mathrm{LL}}^{\mathrm{L}} \pi_{\mathrm{HH}}^{\mathrm{H}}-\pi_{\mathrm{LH}}^{\mathrm{L}} \pi_{\mathrm{HL}}^{\mathrm{H}}=-\lambda^{\mathrm{H}} \mathrm{F}^{\prime \prime}\left(\mathrm{q}^{\mathrm{H}}\right) \mathrm{R}_{\mathrm{LL}}^{\mathrm{L}}-\lambda^{\mathrm{L}} \mathrm{F}^{\prime \prime}\left(\mathrm{q}^{\mathrm{L}}\right) \pi_{\mathrm{HH}}^{\mathrm{H}}>0 .
$$

It follows from (15) and (16) that conditional on a particular country producing the high or low quality, the equilibrium is unique and stable.

In deciding on quality, the firms face two basic considerations. The first is the profitability of the location in quality space based on revenues and the cost of investment in quality for a given distance from the rival's quality as measured by the quality ratio, $r$. The second is the effect of 
induced changes in the quality ratio, which determines the degree of price competition. For firm L, since an increase in $\mathrm{q}^{\mathrm{L}}$ serves to reduce $\mathrm{r}$ (holding $\mathrm{q}^{\mathrm{H}}$ fixed), the associated increase in price competition, tends to reduce firm L's marginal revenue, $\mathrm{R}_{L}^{\mathrm{L}}$, from quality (i.e. the term $r \phi^{\prime}(r)$ enters negatively). Indeed, as shown by (14), $\mathrm{R}_{\mathrm{L}}^{\mathrm{L}}$ is positive only if the products are sufficiently differentiated to make $r \geq 7 / 4$. Nevertheless, for any $q^{H}$, firm $L$ has an incentive to set $q^{L}>0$, because its marginal profit from a very low quality is always strictly positive ${ }^{12}$. Since there is no cost of investment at $\mathrm{q}^{\mathrm{L}}=0$ (i.e. $\mathrm{F}(0)=0$ from (1)), this ensures that entry as a low quality producer is always profitable and hence that both firms enter. For firm $\mathrm{H}$, the prospect of reduced price competition as $r$ is increased, taking $\mathrm{q}^{\mathrm{L}}$ as fixed, gives an incentive to increase quality. The tradeoff is that an increase in $\mathrm{q}^{\mathrm{H}}$ becomes increasingly costly because of the rising marginal cost of investment in quality.

As illustrated in Figure 1, the reaction functions, denoted $q^{\mathrm{H}}=\rho^{\mathrm{H}}\left(\mathrm{q}^{\mathrm{L}}\right)$ and $\mathrm{q}^{\mathrm{L}}=\rho^{\mathrm{L}}\left(\mathrm{q}^{\mathrm{H}}\right)$ for firms $\mathrm{H}$ and $\mathrm{L}$ respectively, have positive slopes, making the products strategic complements in quality space: i.e. from (14) and (15),

$$
\mathrm{dq} / \mathrm{dq}^{\mathrm{L}} \equiv-\mathrm{R}_{\mathrm{HL}^{\mathrm{H}}}^{\mathrm{H}} / \pi_{\mathrm{HH}}^{\mathrm{H}}=\mathrm{rR}_{\mathrm{HH}^{\mathrm{H}}}^{\mathrm{H}} / \pi_{\mathrm{HH}}^{\mathrm{H}}>0 ; \mathrm{dq}^{\mathrm{L}} / \mathrm{dq}^{\mathrm{H}} \equiv-\mathrm{R}_{\mathrm{LH}}^{\mathrm{L}} / \pi_{\mathrm{LL}}^{\mathrm{L}}=\mathrm{R}_{\mathrm{LL}}^{\mathrm{L}} / \mathrm{r}^{\mathrm{L}}{ }_{\mathrm{LL}}>0 .
$$

Thus in response to the greater price competition arising from an increase in $\mathrm{q}^{\mathrm{L}}$, firm $\mathrm{H}$ eases this competition by also increasing $\mathrm{q}^{\mathrm{H}}$. Correspondingly, the reduced competition associated with an increase in $\mathrm{q}^{\mathrm{H}}$ allows firm $\mathrm{L}$ to better position its product by raising $\mathrm{q}^{\mathrm{L}}$. The second order and stability conditions (15) and (16) ensure that firm L's reaction function is steeper than for firm $\mathrm{H}$ and hence that the curves cross at a unique point (shown as N). Since $\mathrm{r}=\mathrm{q}^{\mathrm{H}} / \mathrm{q}^{\mathrm{L}}>1$, the reaction functions both lie above the (dotted) $45^{\circ}$ line.

\footnotetext{
${ }^{12}$ Adapting Ronen (1991) for $\gamma \geq 1$, since $r>7 / 4$ as $q^{L} \rightarrow 0$ and $F^{\prime}(0)=0$ (see (1)), it follows, using (14), that $\lim _{q^{L} \rightarrow 0} \pi_{\mathrm{L}}^{\mathrm{L}}=\lim _{q^{L} \rightarrow 0} \mathrm{R}_{\mathrm{L}}^{\mathrm{L}}-\gamma \mathrm{F}^{\prime}(0)>0$ for any $\mathrm{q}^{\mathrm{H}}$.
} 


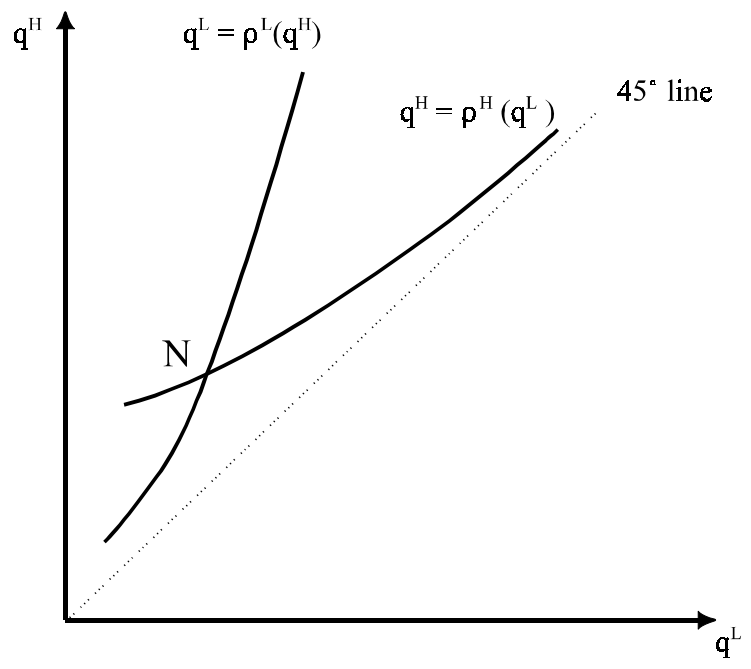

Figure 1 Quality reaction functions: Bertrand competition

Turning to the question as to which country produces which quality, for Bertrand competition, Ronnen (1991) has shown that if the firms are identical $\left(\lambda^{\mathrm{L}}=\lambda^{\mathrm{H}}\right.$ in our setting) then there exists a global equilibrium in which the unique qualities $\left(\mathrm{q}^{\mathrm{L}}, \mathrm{q}^{\mathrm{H}}\right)$ can be produced by either firm. Thus there are two pure-strategy equilibria depending on which firm produces which product. For asymmetric firms, we show in Proposition 1 that the second, "switched" equilibrium, in which firm 1 in the LDC produces $\mathrm{q}^{\mathrm{H}}$ and firm 2, in the developed country, produces $\mathrm{q}^{\mathrm{L}}$ can be ruled out by setting $\gamma$ sufficiently large. For this result, it is important that investment costs increase sufficiently fast with quality (due to $F^{\prime \prime}(q)>0$ and $F^{\prime \prime \prime}(q) \geq 0$ ) that the LDC firm does not leapfrog its quality above the high quality produced by firm $\mathrm{H}$.

Proposition 1. Assume Bertrand price competition. Under conditions (1), if $\gamma \geq 1$ is sufficiently large, there exists a unique pure strategy equilibrium in which the low quality product is produced in the LDC and the high quality product is produced in the developed country.

Proof: See Appendix A

For the subsequent analysis, we assume that $\gamma$ is sufficiently large for Proposition 1 to apply and 
hence that firm L (or firm 1) produces the low-quality product in the LDC and firm $\mathrm{H}$ (or firm 2) produces the high-quality product in the developed country, country $\mathrm{H}$.

\subsection{LDC investment policy towards the low-quality product}

Now considering government policy committed at stage 0 , this section concerns the effects of an LDC subsidy (or tax) applied to investment in quality by firm L. We also adjust firm H's cost so as to include any subsidy (or tax) imposed by country H. Effects on quality levels and profits are first developed before examining the policy that maximizes LDC welfare taking the policy of country $\mathrm{H}$ as given.

Letting $\mathrm{s}^{\mathrm{L}}$ and $\mathrm{s}^{\mathrm{H}}$ represent the proportion of the cost of investment in quality covered by the governments in the LDC and developed countries respectively, we assume ${ }^{13} s^{\mathrm{L}}<1$ and $s^{\mathrm{H}}<1$, with $\mathrm{s}^{\mathrm{L}}<0$ or $\mathrm{s}^{\mathrm{H}}<0$, corresponding to a tax. Thus the cost of investment for firm $\mathrm{L}$ is $\lambda^{\mathrm{L}} \mathrm{F}\left(\mathrm{q}^{\mathrm{L}}\right)$ where $\lambda^{\mathrm{L}}$ $=\left(1-s^{\mathrm{L}}\right) \gamma>0$ and the cost of investment for firm $\mathrm{H}$ is $\lambda^{\mathrm{H}} \mathrm{F}\left(\mathrm{q}^{\mathrm{H}}\right)$ where $\lambda^{\mathrm{H}}=1-\mathrm{s}^{\mathrm{H}}>0$. Letting $\mathrm{q}^{\mathrm{L}}=$ $\mathrm{q}^{\mathrm{L}}\left(\lambda^{\mathrm{L}}, \lambda^{\mathrm{H}}\right)$ and $\mathrm{q}^{\mathrm{H}}=\mathrm{q}^{\mathrm{H}}\left(\lambda^{\mathrm{L}}, \lambda^{\mathrm{H}}\right)$ represent the relationships between quality and costs, $\lambda^{\mathrm{L}}$ and $\lambda^{\mathrm{H}}$, as defined by (13), it follows that $\mathrm{s}^{\mathrm{L}}$ and $\mathrm{s}^{\mathrm{H}}$ have an indirect effect on prices through quality changes. However, since investment costs are sunk at stage 2, there is no change in the second-stage price equilibrium for given levels of quality.

As shown in Proposition 2(a), an investment subsidy by the LDC increases both $\mathrm{q}^{\mathrm{L}}$ and $\mathrm{q}^{\mathrm{H}}$, enhancing the quality levels chosen by both firms, but since the quality ratio $r \equiv q^{H} / q^{L}$ falls, overall the products become more similar. This follows since in response to an increase in $\mathrm{q}^{\mathrm{L}}$ (due to the subsidy), firm $\mathrm{H}$ eases price competition by also increasing its quality $\left(\mathrm{q}^{\mathrm{L}}\right.$ and $\mathrm{q}^{\mathrm{H}}$ are strategic complements), but, the increase in $\mathrm{q}^{\mathrm{H}}$ is not sufficient to prevent a fall in r. From (10), qualityadjusted prices, $\mathrm{p}^{\mathrm{L}}$ and $\mathrm{p}^{\mathrm{H}}$ then fall and outputs, $\mathrm{x}^{\mathrm{L}}$ and $\mathrm{x}^{\mathrm{H}}$ rise. Not surprisingly, as shown in

\footnotetext{
${ }^{13}$ Countries have no incentive to set $\mathrm{s}^{\mathrm{L}} \geq 1$ or $\mathrm{s}^{\mathrm{H}} \geq 1$, since then quality would be increased indefinitely (this violates the first order conditions (13)).
} 
2(b),firm L enjoys higher profits, but the profits of firm $\mathrm{H}$ are reduced.

Proposition 2. Under Bertrand competition, an increase in the investment subsidy, ${ }^{L}$, by the LDC:

(a) raises both $q^{L}$ and $q^{H}$, but $r=q^{H} / q^{L}$ falls, increasing price competition between the firms.

(b) increases profit, $\pi^{L}$, in the LDC and reduces $\pi^{H}$.

Proof: (a) Since $\lambda^{\mathrm{L}}=\left(1-\mathrm{s}^{\mathrm{L}}\right) \gamma$, from (A.1) in Appendix A, we obtain

$$
\mathrm{dq} / \mathrm{ds}^{\mathrm{L}}=-\gamma \mathrm{F}^{\prime}\left(\mathrm{q}^{\mathrm{L}}\right) \pi_{\mathrm{HH}}^{\mathrm{H}} / \mathrm{D}>0 \text { and } \mathrm{dq} \mathrm{H}^{\mathrm{H}} / \mathrm{ds}^{\mathrm{L}}=\gamma \mathrm{F}^{\prime}\left(\mathrm{q}^{\mathrm{L}}\right) \mathrm{R}^{\mathrm{H}}{ }_{\mathrm{HL}} / \mathrm{D}>0 \text {, }
$$

where $\mathrm{D}>0$ from (16). From $\left.\mathrm{dr} / \mathrm{dq}^{\mathrm{L}}=\left[\left(\mathrm{dq}^{\mathrm{H}} / \mathrm{dq}^{\mathrm{L}}\right)-\mathrm{r}\right)\right] / \mathrm{q}^{\mathrm{L}}$ and $\mathrm{dq} / \mathrm{dq} \mathrm{q}^{\mathrm{L}}=\mathrm{rR}_{\mathrm{HH}}^{\mathrm{H}} / \pi_{\mathrm{HH}}^{\mathrm{H}}$ from (17), we also obtain $\mathrm{dr} / \mathrm{dq}^{\mathrm{L}}=\mathrm{r} \lambda^{\mathrm{H}} \mathrm{F}^{\prime \prime}\left(\mathrm{q}^{\mathrm{H}}\right) / \pi^{\mathrm{H}}{ }_{\mathrm{HH}} \mathrm{q}^{\mathrm{L}}$ and hence, using (18), it follows that

$$
\mathrm{dr} / \mathrm{ds}^{\mathrm{L}}=\left(\mathrm{dr} / \mathrm{dq}^{\mathrm{L}}\right)\left(\mathrm{dq}^{\mathrm{L}} / \mathrm{ds}^{\mathrm{L}}\right)=-\mathrm{r} \lambda^{\mathrm{H}} \gamma \mathrm{F}^{\prime \prime}\left(\mathrm{q}^{\mathrm{H}}\right) \mathrm{F}^{\prime}\left(\mathrm{q}^{\mathrm{L}}\right) / \mathrm{D}<0 .
$$

(b) From (12), using $\pi_{\mathrm{L}}^{\mathrm{L}}=0, \pi_{\mathrm{H}}^{\mathrm{H}}=0, \lambda^{\mathrm{L}}=\gamma\left(1-\mathrm{s}^{\mathrm{L}}\right), \mathrm{R}_{\mathrm{H}}^{\mathrm{L}}>0, \mathrm{R}_{\mathrm{L}}^{\mathrm{H}}<0$ (see (11)) and (18), we obtain

$$
\mathrm{d} \pi^{\mathrm{L}} / \mathrm{ds}^{\mathrm{L}}=\mathrm{R}_{\mathrm{H}}^{\mathrm{L}}\left(\mathrm{dq} \mathrm{H}^{\mathrm{H}} / \mathrm{ds}^{\mathrm{L}}\right)+\gamma \mathrm{F}\left(\mathrm{q}^{\mathrm{L}}\right)>0 \text { and } \mathrm{d} \pi^{\mathrm{H}} / \mathrm{ds}^{\mathrm{L}}=\mathrm{R}_{\mathrm{L}}^{\mathrm{H}}\left(\mathrm{dq}^{\left.\mathrm{L} / \mathrm{ds}^{\mathrm{L}}\right)<0 .}\right.
$$

Next considering LDC welfare, since all of the good is exported, welfare in the LDC, given by $\mathrm{W}^{\mathrm{L}} \equiv \pi^{\mathrm{L}}\left(\mathrm{q}^{\mathrm{L}}, \mathrm{q}^{\mathrm{H}} ; \lambda^{\mathrm{L}}\right)-\mathrm{s}^{\mathrm{L}} \gamma \mathrm{F}\left(\mathrm{q}^{\mathrm{L}}\right)$ for $\lambda^{\mathrm{L}}=\left(1-\mathrm{s}^{\mathrm{L}}\right) \gamma$, is simply the profit from these exports less the cost of the subsidy, $\mathrm{s}^{\mathrm{L}}$, to taxpayers. At the Nash quality equilibrium, letting $\mathrm{s}^{\mathrm{L} *}$ maximize $\mathrm{W}^{\mathrm{L}}$ taking $\mathrm{s}^{\mathrm{H}}$ as given, we show in Proposition 3 that $\mathrm{s}^{\mathrm{L} *}>0$. Thus, taking account of effects on the subsequent game played by firms, a subsidy to investment in $\mathrm{q}^{\mathrm{L}}$ raises LDC profits by more than the cost to taxpayers.

Proposition 3. Under Bertrand competition, the LDC gains from a subsidy to investment in $q^{L}$. Proof. Using (20) and $\mathrm{q}^{\mathrm{H}}=\rho^{\mathrm{H}}\left(\mathrm{q}^{\mathrm{L}} ; \lambda^{\mathrm{H}}\right)$ where $\lambda^{\mathrm{H}}=1-\mathrm{s}^{\mathrm{H}}$ is taken as given, it follows that $\mathrm{dW}^{\mathrm{L}} / \mathrm{ds}^{\mathrm{L}}=$ $\left[\mathrm{R}_{\mathrm{H}}^{\mathrm{L}}\left(\mathrm{dq}^{\mathrm{H}} / \mathrm{dq}^{\mathrm{L}}\right)-\mathrm{s}^{\mathrm{L}} \gamma \mathrm{F}^{\prime}\left(\mathrm{q}^{\mathrm{L}}\right)\right]\left(\mathrm{dq} \mathrm{L}^{\mathrm{L}} / \mathrm{ds}^{\mathrm{L}}\right)$ and hence using (11) and (17)) that $\mathrm{s}^{\mathrm{L} *}=\mathrm{R}_{\mathrm{H}}^{\mathrm{L}}\left(\mathrm{dq}^{\mathrm{H}} / \mathrm{dq}^{\mathrm{L}}\right) / \gamma \mathrm{F}^{\prime}\left(\mathrm{q}^{\mathrm{L}}\right)$ $>0$. As shown in Proposition 4(ii) below, we have $d^{2} W^{\mathrm{L}} /\left(\mathrm{ds}^{\mathrm{L}}\right)^{2}<0$ at $\mathrm{s}^{\mathrm{L}}=\mathrm{s}^{\mathrm{L}^{*}}$.

To explain this result, we first consider the choice of quality supposing that the low quality firm is a Stackelberg leader in quality space, but there is no subsidy. Proposition 4 then shows that 
the subsidy, $\mathrm{s}^{\mathrm{L} *}$, maximizes the LDC's rents from exports by shifting the equilibrium to what would have been the Stackelberg leader-follower point in quality space ${ }^{14}$. This result follows essentially because for any quality $q^{\mathrm{L}}, \mathrm{LDC}$ welfare is simply the profit of firm $\mathrm{L}$ at $\mathrm{s}^{\mathrm{L}}=0$ : i.e. expanding $\mathrm{W}^{\mathrm{L}}$ using (12), we have

$$
W^{L}=\pi^{L}\left(q^{L}, q^{H}, \gamma\right)=R^{L}\left(q^{L}, q^{H}\right)-\gamma F\left(q^{L}\right) \text { for } q^{H}=\rho^{H}\left(q^{L}\right)
$$

We assume that $\gamma$ is sufficiently large that, as shown in Proposition 4, the LDC firm as a Stackelberg leader would not choose to leapfrog so as to become the high-quality producer ${ }^{15}$. Proposition 4 also demonstrates the concavity of the leader's profit in $\mathrm{q}^{\mathrm{L}}$ and hence the local concavity of LDC welfare at $\mathrm{S}^{\mathrm{L}^{*}}$.

Proposition 4. Assume Bertrand competition. (i) The subsidy, $s^{L *}$, maximizes the LDC's rents from exports by shifting the equilibrium to what would have been the Stackelberg leader-follower point in quality space with the low quality firm as the leader and no subsidy. For $\gamma$ sufficiently large, the LDC firm does not choose to become the high quality producer. (ii) Under conditions (1), profit $\pi^{L}\left(q^{L}, \rho^{H}\left(q^{L}\right), \lambda^{L}\right)$ of the leader firm is (strictly) globally concave in $q^{L}$ and LDC welfare, $W^{L}$, is locally concave at $s^{L}=s^{L *}$.

Proof. See Appendix A.

Since the quality $\mathrm{q}^{\mathrm{H}}$ is increasing in $\mathrm{q}^{\mathrm{L}}$ (firm $\mathrm{H}$ 's reaction function has a positive slope) and since, for any $\mathrm{q}^{\mathrm{L}}$, firm $\mathrm{L}$ benefits from an increase in $\mathrm{q}^{\mathrm{H}}$ (i.e. $\mathrm{R}_{\mathrm{H}}^{\mathrm{L}}>0$ from (11)), firm $\mathrm{L}$ as a Stackelberg leader would increase quality $\mathrm{q}^{\mathrm{L}}$ above the Nash equilibrium level ${ }^{16}$. Consequently, in a situation of Nash behavior by firms in quality space, the optimal policy in the LDC involves a

\footnotetext{
${ }^{14}$ The general principle is the same as in Spencer and Brander (1993, Proposition 3).

${ }^{15}$ This follows because the rate of increase in investment costs is magnified as $\gamma$ increases.

${ }^{16}$ More formally, $\mathrm{d} \pi^{\mathrm{L}} / \mathrm{dq}^{\mathrm{L}}=\pi_{\mathrm{L}}^{\mathrm{L}}+\mathrm{R}_{\mathrm{H}}^{\mathrm{L}}\left(\mathrm{dq}^{\mathrm{H}} / \mathrm{dq}^{\mathrm{L}}\right)>0$ at $\pi_{\mathrm{L}}^{\mathrm{L}}=0$.
} 
subsidy to investment in quality. Since $r=q^{H} / q^{L}$ falls (see Proposition 2(a)), qualities actually become more similar, which increases price competition, but by increasing its quality, firm L nevertheless gains from a better positioning of its product in quality space. Fundamentally, the subsidy corrects for the fact that, by taking $\mathrm{q}^{\mathrm{H}}$ as given, firm $\mathrm{L}$ sets $\mathrm{q}^{\mathrm{L}}$ too low due to its overestimate of the increase in price competition from an increase in $\mathrm{q}^{\mathrm{L}}$. As for the role of government, this arises because firms are constrained by the Nash assumption that they take the rival's quality as given. The underlying insight of strategic trade policy is that government subsidy and tax policy can change the incentives faced by firms at the start of the competition and hence shift the outcome to a more favorable equilibrium from the viewpoint of the government concerned.

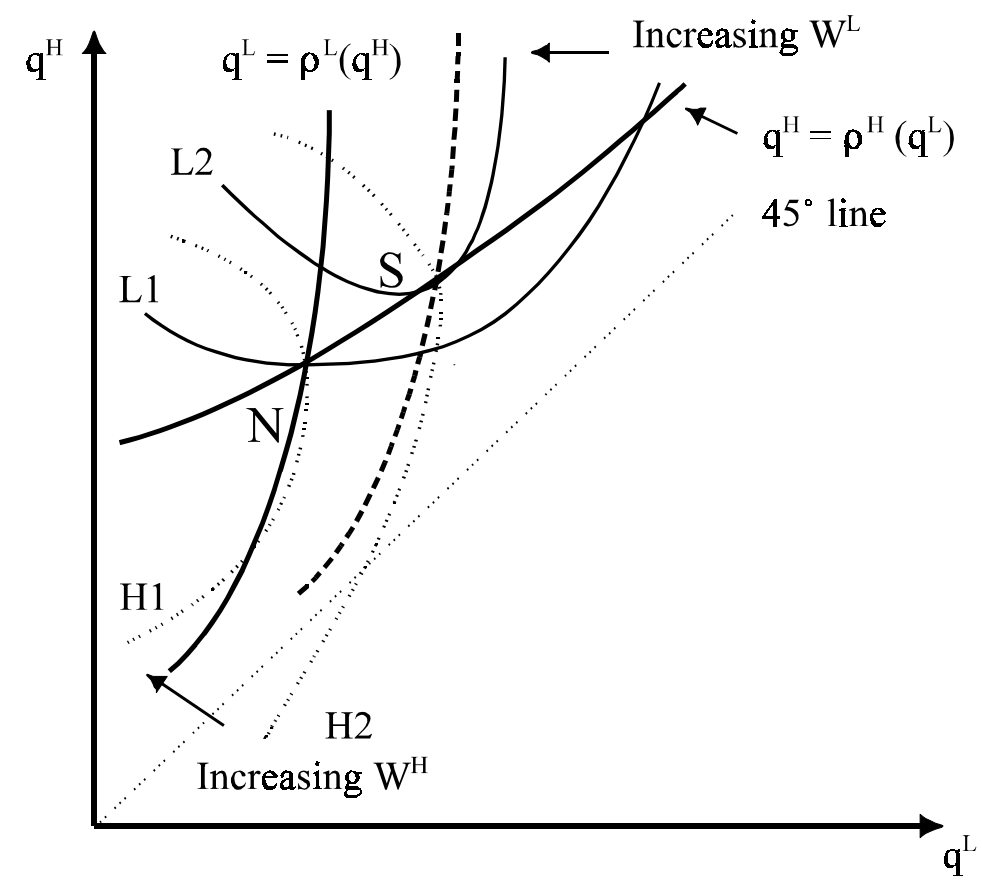

Figure 2 The LDC's optimal subsidy: Bertrand competition

These results are illustrated in Figure 2. Starting from the Nash equilibrium at point N, the subsidy, $\mathrm{s}^{\mathrm{L} *}$, shifts firm L's quality reaction function to the right (shown as the dashed line), resulting in a new Nash equilibrium at point $S$. This causes a net increase in LDC profit at the expense of firm $\mathrm{H}$ and, as a result, the LDC moves to a higher iso-welfare contour (from L1 to L2) while country H, 
moves to a lower iso-welfare contour (from H1 to H2). Since the contour L2, based on firm L's profits less the cost of the subsidy, is tangent to firm H's reaction function at $\mathrm{S}$, point $\mathrm{S}$ also represents the outcome if firm L were a Stackelberg leader in quality space in the absence of a subsidy.

\subsection{Developed country policy towards the high-quality product}

The effects of an investment subsidy, $\mathrm{s}^{\mathrm{H}}$, set by the developed country, country $\mathrm{H}$, are set out in Proposition 5. As shown in 5(a), as was the case for $\mathrm{s}^{\mathrm{L}}$, an increase in $\mathrm{s}^{\mathrm{H}}$ causes the quality of both products to rise. However, in contrast to the effect of $s^{L}$, the quality ratio $r \equiv q^{H} / q^{L}$ increases, making the products more differentiated. This difference arises because $\mathrm{s}^{\mathrm{H}}$ works through raising $\mathrm{q}^{\mathrm{H}}$ which directly raises $r$ and $s^{\mathrm{L}}$ works through raising $\mathrm{q}^{\mathrm{L}}$ which directly lowers $\mathrm{r}$. Although the rival firm also raises quality in each case (since $\mathrm{q}^{\mathrm{L}}$ and $\mathrm{q}^{\mathrm{H}}$ are strategic complements), the initial effect dominates. Since $r$ is increased, the reduced price competition results in higher quality-adjusted prices and lower outputs for both products(see (10)).

As shown in 5(b), the differing effects of the two policies, $\mathrm{s}^{\mathrm{L}}$ and $\mathrm{s}^{\mathrm{H}}$, on the degree of product differentiation also translates into differing effects on profits. Whereas an increase in $\mathrm{s}^{\mathrm{L}}$ decreases the profit of firm $\mathrm{H}$, the lessening of competition due to an increase in $\mathrm{s}^{\mathrm{H}}$ serves to boost the profits of the rival low-quality firm. Interestingly, it is not obvious that an increase in $\mathrm{s}^{\mathrm{H}}$ raises the profit of firm $H$. The problem arises because the increase in $q^{L}$ due to $s^{H}>0$ causes a reduction in firm $H^{\prime} s$ revenue, which tends to offset the direct effect of the subsidy in lowering firm H's costs. However, using the assumptions $\mathrm{F}^{\prime \prime}(\mathrm{q})>0$ and $\mathrm{F}^{\prime \prime \prime}(\mathrm{q}) \geq 0$ (from (1)), we are able to show (see Lemma 1 , Appendix A) that firm H's profit will indeed rise. The basic intuition is that if investment costs increase sharply with quality, this limits the extent to which both $\mathrm{q}^{\mathrm{H}}$ and $\mathrm{q}^{\mathrm{L}}$ rise, and hence causes the direct reduction in costs from the subsidy to dominate.

Proposition 5. Under Bertrand competition, an increase in the investment subsidy, $s^{H}$, to firm $H$ : 
(a) raises both $q^{H}$ and $q^{L}$, but $r=q^{H} / q^{L}$ increases, reducing price competition between the firms.

(b) increases the profits, $\pi^{L}$ and $\pi^{H}$, of both firms.

Proof. (a). Since $\lambda^{\mathrm{H}}=1-\mathrm{s}^{\mathrm{H}}$, from (A.1) in Appendix A, we obtain $\mathrm{dq} / \mathrm{H} / \mathrm{ds}^{\mathrm{H}}=-\mathrm{F}^{\prime}\left(\mathrm{q}^{\mathrm{H}}\right) \pi^{\mathrm{L}}{ }_{\mathrm{L}} / \mathrm{D}>0$ and $\mathrm{dq} / \mathrm{ds}^{\mathrm{H}}=\mathrm{F}^{\prime}\left(\mathrm{q}^{\mathrm{H}}\right) \mathrm{R}_{\mathrm{LH}}^{\mathrm{L}} / \mathrm{D}>0$. Then, using $\mathrm{dq} / \mathrm{dq}^{\mathrm{H}}=\mathrm{R}_{\mathrm{LL}}^{\mathrm{L}} / \mathrm{r}^{\mathrm{L}}{ }_{\mathrm{LL}}$ from (17), we obtain $\mathrm{dr} / \mathrm{dq}^{\mathrm{H}}=-$ $\lambda^{\mathrm{L}} \gamma \mathrm{F}^{\prime \prime}\left(\mathrm{q}^{\mathrm{L}}\right) / \pi^{\mathrm{L}} \mathrm{L}^{\mathrm{L}}>0$ and $\mathrm{dr} / \mathrm{ds}^{\mathrm{H}}=\left(\mathrm{dr} / \mathrm{dq}^{\mathrm{H}}\right)\left(\mathrm{dq}^{\mathrm{H}} / \mathrm{ds}^{\mathrm{H}}\right)>0$. (b). From (12) using $\pi_{\mathrm{L}}^{\mathrm{L}}=\pi_{\mathrm{H}}^{\mathrm{H}}=0$ and $\mathrm{d} \pi^{\mathrm{H}} / \mathrm{d} \lambda^{\mathrm{H}}<0$ from Lemma 1 in Appendix A, we obtain: $\mathrm{d} \pi^{\mathrm{L}} / \mathrm{ds}^{\mathrm{H}}=\mathrm{R}^{\mathrm{L}}{ }_{\mathrm{H}}\left(\mathrm{dq}^{\mathrm{H}} / \mathrm{ds}^{\mathrm{H}}\right)>0$ and $\mathrm{d} \pi^{\mathrm{H}} / \mathrm{ds}^{\mathrm{H}}$ $=\mathrm{R}_{\mathrm{L}}^{\mathrm{H}}\left(\mathrm{dq}^{\mathrm{L}} / \mathrm{ds}^{\mathrm{L}}\right)+\mathrm{F}\left(\mathrm{q}^{\mathrm{H}}\right)>0$.

Next, letting $\mathrm{W}^{\mathrm{H}} \equiv \pi^{\mathrm{H}}\left(\mathrm{q}^{\mathrm{L}}, \mathrm{q}^{\mathrm{H}} ; 1-\mathrm{s}^{\mathrm{H}}\right)-\mathrm{s}^{\mathrm{H}} \mathrm{F}\left(\mathrm{q}^{\mathrm{H}}\right)$ denote welfare in country $\mathrm{H}$, as shown in Proposition 6, for any given value of $\mathrm{s}^{\mathrm{L}}$, country $\mathrm{H}$ has an incentive to tax the investment of its firm. Although the tax reduces the profits of firm $\mathrm{H}$, this is more than offset by the additional tax revenue. Letting $\mathrm{s}^{\mathrm{H}^{*}}<0$ represent the optimal tax, the proof assumes local concavity of $\mathrm{W}^{\mathrm{H}}$ at $\mathrm{s}^{\mathrm{H}}=\mathrm{s}^{\mathrm{H}^{*}}$. In Lemma 2 (see Appendix A), this condition is shown to hold for the class of investment cost functions, $\mathrm{F}(\mathrm{q})=\mathrm{a}(\mathrm{q})^{\mathrm{n}}$ for $\mathrm{n} \geq 2$.

Proposition 6. Under Bertrand competition, country H has an incentive to tax investment in $q^{H}$ Proof. Assume $\mathrm{d}^{2} \mathrm{~W}^{\mathrm{H}} /\left(\mathrm{ds}^{\mathrm{H}}\right)^{2}<0$ at $\mathrm{s}^{\mathrm{H} *}$. Using $\mathrm{d} \pi^{\mathrm{H}} / \mathrm{ds}^{\mathrm{H}}=\mathrm{R}_{\mathrm{L}}^{\mathrm{H}}\left(\mathrm{dq}^{\mathrm{L}} / \mathrm{ds}^{\mathrm{L}}\right)+\mathrm{F}\left(\mathrm{q}^{\mathrm{H}}\right)$, we obtain $\mathrm{dW}^{\mathrm{H}} / \mathrm{ds}^{\mathrm{H}}=$ $\left[\mathrm{R}_{\mathrm{L}}^{\mathrm{H}}\left(\mathrm{dq}^{\mathrm{L}} / \mathrm{dq}^{\mathrm{H}}\right)-\mathrm{s}^{\mathrm{H}} \mathrm{F}^{\prime}\left(\mathrm{q}^{\mathrm{H}}\right)\right]\left(\mathrm{dq}^{\mathrm{H}} / \mathrm{ds}^{\mathrm{H}}\right)$ and hence $\mathrm{s}^{\mathrm{H} *}=\mathrm{R}_{\mathrm{L}}^{\mathrm{H}}\left(\mathrm{dq}^{\mathrm{L}} / \mathrm{dq}^{\mathrm{H}}\right) / \mathrm{F}^{\prime}\left(\mathrm{q}^{\mathrm{H}}\right)<0$ from (17) and (11).

Just as in Proposition 4 concerning policy by the LDC, the tax, $\mathrm{s}^{\mathrm{H}^{*}}$, maximizes the rents that country $\mathrm{H}$ earns from exports by shifting the equilibrium to what would have been the Stackelberg leader-follower point in quality space with firm $\mathrm{H}$ as the leader and no tax ${ }^{17}$. Since the quality, $\mathrm{q}^{\mathrm{L}}$, set by the LDC firm is increasing in $\mathrm{q}^{\mathrm{H}}$ (firm L's reaction function has a positive slope) and since, for any given $\mathrm{q}^{\mathrm{H}}$, the revenues of firm $\mathrm{H}$ are reduced by an increase in $\mathrm{q}^{\mathrm{L}}\left(\right.$ i.e. $\mathrm{R}_{\mathrm{L}}^{\mathrm{H}}<0$ from (11)),

\footnotetext{
${ }^{17}$ The general point is well understood and we omit the proof.
} 
the Stackelberg leader would reduce $\mathrm{q}^{\mathrm{H}}$ below the level implied by the Nash equilibrium ${ }^{18}$. Consequently, if firms follow Nash behavior in quality space, then the optimal policy for country $\mathrm{H}$ is an investment tax so as to reduce the quality, $\mathrm{q}^{\mathrm{H}}$, produced by firm H. From Proposition 5(a), the actual effect of the tax is to reduce the separation between qualities, which increases price competition. Nevertheless, firm $\mathrm{H}$ gains from a reduction in the quality of its product. Fundamentally, the tax corrects for the fact that, by taking $\mathrm{q}^{\mathrm{L}}$ as given, firm $\mathrm{H}$ sets $\mathrm{q}^{\mathrm{H}}$ too high due to its over estimate of the effect of an increase in $\mathrm{q}^{\mathrm{H}}$ in reducing price competition.

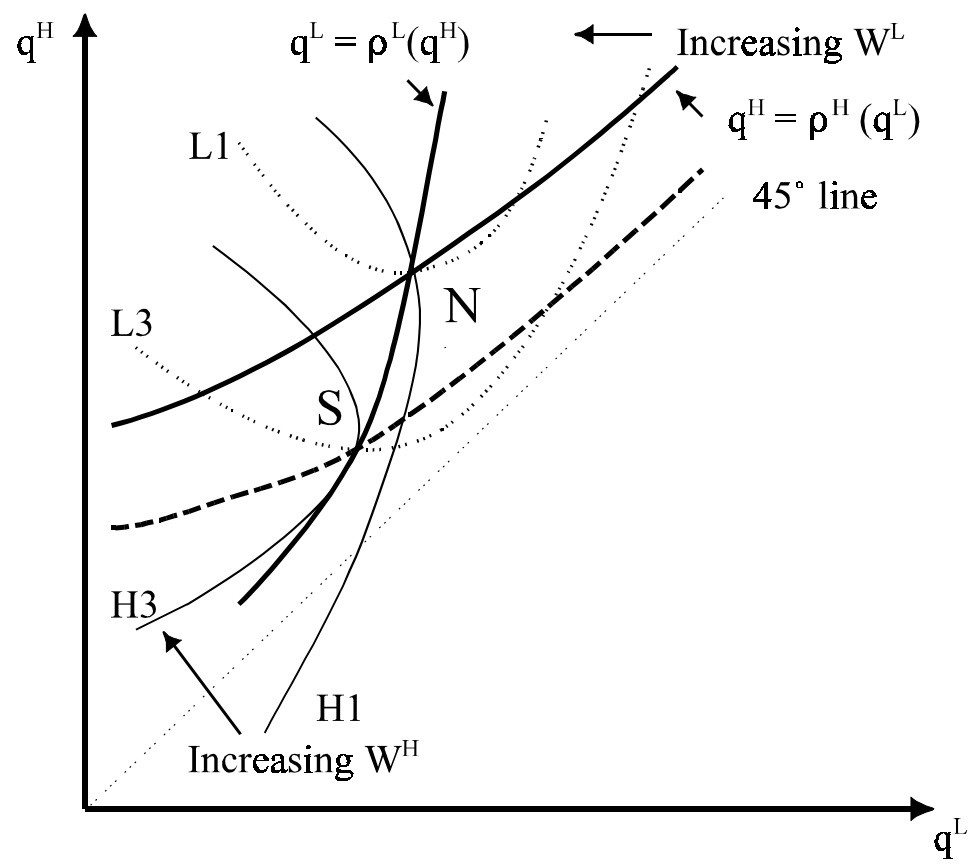

Figure 3 The developed country's optimal tax: Bertrand competition

These results are illustrated in Figure 3. Starting from the Nash equilibrium at point $\mathrm{N}$, the tax, $\mathrm{s}^{\mathrm{H} *}$, shifts down the reaction function of firm $\mathrm{H}$ (shown as the dashed line), resulting in a new Nash equilibrium at point $\mathrm{S}$. As a result, the developed country moves to a higher iso-welfare contour

${ }^{18}$ More formally, $\mathrm{d} \pi^{\mathrm{H}} / \mathrm{dq}^{\mathrm{H}}=\pi_{\mathrm{H}^{\mathrm{H}}}^{\mathrm{H}}+\mathrm{R}_{\mathrm{L}}^{\mathrm{H}}\left(\mathrm{dq}^{\mathrm{L}} / \mathrm{dq}^{\mathrm{H}}\right)<0$ at $\pi_{\mathrm{H}}^{\mathrm{H}}=0$. 
(from $\mathrm{H} 1$ to $\mathrm{H} 3$ ) while the LDC moves to a lower iso-welfare contour (from L1 to L3). Since H3 is tangent to the reaction function of the LDC firm, point $\mathrm{S}$ also represents the outcome if firm $\mathrm{H}$ were a Stackelberg leader and $\mathrm{s}^{\mathrm{H}}=0$.

To explain why the policy is a tax in country $\mathrm{H}$ and a subsidy in the LDC, recall that firm $\mathrm{H}$ gains from a reduction in the quality, $\mathrm{q}^{\mathrm{L}}$, of its rival, whereas firm $\mathrm{L}$ gains from an increase in quality, $\mathrm{q}^{\mathrm{H}}$. Since in both cases, quality reaction functions are positively sloped, by reducing $\mathrm{q}^{\mathrm{H}}$, the tax in country $\mathrm{H}$ serves to reduce $\mathrm{q}^{\mathrm{L}}$ and conversely, by raising $\mathrm{q}^{\mathrm{L}}$, the subsidy in the LDC serves to raise $\mathrm{q}^{\mathrm{H}}$. However, since the $\mathrm{LDC}$ would like to increase $\mathrm{q}^{\mathrm{H}}$ but country $\mathrm{H}$ taxes $\mathrm{q}^{\mathrm{H}}$ and since country H would like to reduce $\mathrm{q}^{\mathrm{L}}$ but the LDC subsidizes $\mathrm{q}^{\mathrm{L}}$, when both countries intervene, these unilateral incentives for policy tend to undermine the goal of raising profits from exports.

As shown in Proposition 7, the aggregate or joint welfare of the two producing countries can be increased if LDC policy is switched to a tax on investment in $\mathrm{q}^{\mathrm{L}}$ and developed country policy is switched to a subsidy. These joint policies raise producer welfare by taking into account the effects of each firm's choice of quality on its rival's profit. Thus firm $\mathrm{H}$ gains from the reduction in $\mathrm{q}^{\mathrm{L}}$ due to the LDC tax and firm $\mathrm{L}$ gains from the increase in $\mathrm{q}^{\mathrm{H}}$ due to the LDC subsidy. Overall, the two policies increase the separation between the products so as to reduce price competition and better exploit third country consumers ${ }^{19}$.

Proposition 7. Under Bertrand competition, the jointly optimal policies $\left(s^{L J}, s^{H J}\right)$ involve an investment tax in the LDC and an investment subsidy in country H: i.e. $s^{L J}=R^{H}{ }_{L} / \gamma F^{\prime}\left(q^{L}\right)<0$ and $s^{H J}=R_{H}^{L} / F^{\prime}\left(q^{H}\right)>0$.

Proof. See Appendix A.

\footnotetext{
${ }^{19}$ Since $\mathrm{s}^{\mathrm{LJ}}<0$ lowers $\mathrm{q}^{\mathrm{L}}$, this may seem to suggest a broadening in market sales, but since $\mathrm{p}^{\mathrm{L}}$ rises, the range of consumers $\theta \in\left[\mathrm{p}^{\mathrm{L}}, 1\right]$ who purchase either variety of the good is actually reduced.
} 


\section{Investment policy and quality choice under Cournot competition}

We now turn to the case of Cournot competition in which firms choose quantities rather than prices at stage 2 after committing to quality levels at stage 1 . The game played by firms is set out in 4.1 and the respective effects of LDC and developed country policies towards quality are explored in 4.2 and 4.3 .

\subsection{The two-stage model of firm behavior: Cournot competition.}

Examining the second-stage first, we solve for $\mathrm{p}^{\mathrm{L}}=\mathrm{P}^{\mathrm{L}} / \mathrm{q}^{\mathrm{L}}$ and $\mathrm{p}^{\mathrm{H}}=\mathrm{P}^{\mathrm{H}} / \mathrm{q}^{\mathrm{H}}$ from the demand functions (5), so as to obtain the inverse demand functions:

$$
\mathrm{P}^{\mathrm{L}}=\left[1-\left(\mathrm{x}^{\mathrm{L}}+\mathrm{x}^{\mathrm{H}}\right)\right] \mathrm{q}^{\mathrm{L}} \text { and } \mathrm{P}^{\mathrm{H}}=\left[1-\mathrm{x}^{\mathrm{L}} / \mathrm{r}-\mathrm{x}^{\mathrm{H}}\right] \mathrm{q}^{\mathrm{H}} \text {. }
$$

This includes the possibility that both firms set the same qualities (i.e. $\mathrm{q}^{\mathrm{L}}=\mathrm{q}^{\mathrm{H}}$ ), since, setting $\mathrm{r}=1$ in (22), we obtain, $\mathrm{P}^{\mathrm{i}}=\left(1-\left(\mathrm{x}^{\mathrm{L}}+\mathrm{x}^{\mathrm{H}}\right)\right) \mathrm{q}^{\mathrm{i}}$ for $\mathrm{i}=\mathrm{L}, \mathrm{H}$, as in (3). Recalling that productions are zero, for any given qualities, $\mathrm{q}^{\mathrm{L}}$ and $\mathrm{q}^{\mathrm{H}}$, committed at stage 1 , firm $\mathrm{L}$ sets $\mathrm{x}^{\mathrm{L}}$ to maximize its revenue, $\mathrm{R}^{\mathrm{L}}=$ $\mathrm{P}^{\mathrm{L}} \mathrm{x}^{\mathrm{L}}$, taking $\mathrm{x}^{\mathrm{H}}$ as given and firm $\mathrm{H}$ sets $\mathrm{x}^{\mathrm{H}}$ to maximize its revenue, $\mathrm{R}^{\mathrm{H}}=\mathrm{P}^{\mathrm{H}} \mathrm{X}^{\mathrm{H}}$, taking $\mathrm{x}^{\mathrm{L}}$ as given. Thus from (22), $x^{\mathrm{L}}$ and $\mathrm{x}^{\mathrm{H}}$ satisfy the first order conditions: $\partial \mathrm{R}^{\mathrm{L}} / \partial \mathrm{x}^{\mathrm{L}}=\left[1-\left(2 \mathrm{x}^{\mathrm{L}}+\mathrm{x}^{\mathrm{H}}\right)\right] \mathrm{q}^{\mathrm{L}}=0$ and $\partial \mathrm{R}^{\mathrm{H}} / \partial \mathrm{x}^{\mathrm{H}}=\left[1-\left(\mathrm{x}^{\mathrm{L} / \mathrm{r}}+2 \mathrm{x}^{\mathrm{H}}\right)\right] \mathrm{q}^{\mathrm{H}}=0$, where the second order and stability conditions are also satisfied ${ }^{20}$. Also, since $\partial \mathrm{R}^{\mathrm{i}} / \partial \mathrm{x}^{\mathrm{i}}$ is decreasing in $\mathrm{x}^{\mathrm{j}}$ for $\mathrm{i}, \mathrm{j}=\mathrm{L}, \mathrm{H}$ and $\mathrm{i} \neq \mathrm{j}$, the outputs are strategic substitutes as is typical for Cournot competition.

From the first order conditions, we obtain output levels and then quality-adjusted prices (from (22) and (4)) at the Cournot equilibrium as follows:

$$
\mathrm{p}^{\mathrm{L}}=\mathrm{x}^{\mathrm{L}}=\mathrm{r} /(4 \mathrm{r}-1), \mathrm{p}^{\mathrm{H}}=\mathrm{x}^{\mathrm{H}}=(2 \mathrm{r}-1) /(4 \mathrm{r}-1) \text { and } \tilde{\theta}=\left(\mathrm{rp}^{\mathrm{H}}-\mathrm{p}^{\mathrm{L}}\right) /(\mathrm{r}-1)=2 \mathrm{r} /(4 \mathrm{r}-1) .
$$

From (23), it is notable that the quality-adjusted price equals the quantity sold of each product. Also, since $\mathrm{p}^{\mathrm{L}}$ and $\mathrm{x}^{\mathrm{L}}$ both fall and $\mathrm{p}^{\mathrm{H}}$ and $\mathrm{x}^{\mathrm{H}}$ both rise, greater separation in quality, as shown by an

\footnotetext{
${ }^{20}$ We have $\partial^{2} R^{\mathrm{L}} /\left(\partial \mathrm{x}^{\mathrm{L}}\right)^{2}=-2 \mathrm{q}^{\mathrm{L}}<0$ and $\partial^{2} \mathrm{R}^{\mathrm{H}} /\left(\partial \mathrm{x}^{\mathrm{H}}\right)^{2}=-2 \mathrm{q}^{\mathrm{H}}<0$ and, using $\partial^{2} \mathrm{R}^{\mathrm{i}} /\left(\partial \mathrm{x}^{\mathrm{L}}\right)\left(\partial \mathrm{x}^{\mathrm{H}}\right)=-\mathrm{q}^{\mathrm{H}} / \mathrm{r}=-\mathrm{q}^{\mathrm{L}}<$ 0 for $\mathrm{i}=\mathrm{L}, \mathrm{H}$, we obtain $\Omega^{\mathrm{c}} \equiv\left(\partial^{2} \mathrm{R}^{\mathrm{L}} /\left(\partial \mathrm{x}^{\mathrm{L}}\right)^{2}\right)\left(\partial^{2} \mathrm{R}^{\mathrm{H}} /\left(\partial \mathrm{x}^{\mathrm{H}}\right)^{2}\right)-\left(\partial^{2} \mathrm{R}^{\mathrm{i}} /\left(\partial \mathrm{x}^{\mathrm{L}}\right)\left(\partial \mathrm{x}^{\mathrm{H}}\right)\right)^{2}=\mathrm{q}^{\mathrm{L}}\left(4 \mathrm{q}^{\mathrm{H}}-\mathrm{q}^{\mathrm{L}}\right)>0$.
} 
increase in $r$ now has mixed effects on prices and output and hence the degree of competition: i.e. from (23),

$$
\mathrm{dp}^{\mathrm{L}} / \mathrm{dr}=\mathrm{dx} / \mathrm{dr}=-1 /(4 \mathrm{r}-1)^{2}<0 \text { and } \mathrm{dp}^{\mathrm{H}} / \mathrm{dr}=\mathrm{dx}^{\mathrm{H}} / \mathrm{dr}=2 /(4 \mathrm{r}-1)^{2}>0 .
$$

Using a superscript $\mathrm{c}$ to distinguish functions at the Cournot equilibrium, we express the revenues of firms $\mathrm{L}$ and $\mathrm{H}$ as $\mathrm{R}^{\mathrm{cL}}\left(\mathrm{q}^{\mathrm{L}}, \mathrm{q}^{\mathrm{H}}\right)=\omega(\mathrm{r}) \mathrm{q}^{\mathrm{L}}$ and $\mathrm{R}^{\mathrm{cH}}\left(\mathrm{q}^{\mathrm{L}}, \mathrm{q}^{\mathrm{H}}\right)=\psi(\mathrm{r}) \mathrm{q}^{\mathrm{H}}$ respectively, where $\omega(\mathrm{r}) \equiv(\mathrm{r})^{2} /(4 \mathrm{r}-$ $1)^{2}$ and $\psi(r)=(2 r-1)^{2} /(4 r-1)^{2}$ from $(23)$ and

$$
\omega^{\prime}(\mathrm{r})=-2 \mathrm{r} /(4 \mathrm{r}-1)^{3}<0 \text { and } \psi^{\prime}(\mathrm{r})=4(2 \mathrm{r}-1) /(4 \mathrm{r}-1)^{3}>0 .
$$

Thus, holding own qualities fixed, the revenues of the two firms respond in opposite directions with respect to an increase in $r=q^{H} / q^{L}$, with firm L's revenue falling and firm H's revenue rising. This implies that revenues for firm $\mathrm{L}$ as well as for firm $\mathrm{H}$ are decreased by an increase in the rivals quality: i.e.

$$
\mathrm{R}_{\mathrm{H}}^{\mathrm{cL}}=\omega^{\prime}(\mathrm{r})=-2 \mathrm{r} /(4 \mathrm{r}-1)^{3}<0 \text { and } \mathrm{R}_{\mathrm{L}}^{\mathrm{cH}}=-(\mathrm{r})^{2} \psi^{\prime}(\mathrm{r})=-4(\mathrm{r})^{2}(2 \mathrm{r}-1) /(4 \mathrm{r}-1)^{3}<0 .
$$

In contrast with the Bertrand case, firm L now gains as the products become more similar, but, as before, firm $\mathrm{H}$ gains from a greater separation of qualities. To understand these results, first note that, for both models, an increase in $\mathrm{r}$, holding $\mathrm{x}^{\mathrm{L}}$ and $\mathrm{x}^{\mathrm{H}}$ fixed, shifts up the demand curve for good $\mathrm{H}$, raising the willingness of consumers to pay for the high-quality good (i.e. $\partial \mathrm{p}^{\mathrm{H}} / \partial \mathrm{r}=\mathrm{x}^{\mathrm{L}} /(\mathrm{r})^{2}$ $>0$ from (22)), but the willingness to pay for the low-quality good is unchanged (i.e. $\partial \mathrm{p}^{\mathrm{L}} / \partial \mathrm{r}=0$ from (22)). Under Cournot competition, firm $\mathrm{H}$ responds to this higher demand due to greater separation of products by expanding output and firm $\mathrm{L}$ then reacts by cutting output $\left(\mathrm{x}^{\mathrm{L}}\right.$ and $\mathrm{x}^{\mathrm{H}}$ are strategic substitutes). Since quality-adjusted price and output both fall for firm $\mathrm{L}$ and both rise for firm $\mathrm{H}$ (see (24)), firm L's revenue falls (holding $\mathrm{q}^{\mathrm{L}}$ fixed) and firm $\mathrm{H}^{\prime}$ 's revenue increases (holding $\mathrm{q}^{\mathrm{H}}$ fixed). Instead, under Bertrand competition, firm $\mathrm{H}$ raises price in response to an increase in $\mathrm{r}$ and, since $\mathrm{p}^{\mathrm{L}}$ and $\mathrm{p}^{\mathrm{H}}$ are strategic complements, firm $\mathrm{L}$ also raises price (see (10)) causing the revenues of both firms to increase. 
Incorporating the cost of investment for general cost parameters $\lambda^{\mathrm{L}}$ and $\lambda^{\mathrm{H}}$, the respective profits of the low and high quality firms are given by:

$$
\Pi^{\mathrm{L}}\left(\mathrm{q}^{\mathrm{L}}, \mathrm{q}^{\mathrm{H}}\right)=\mathrm{R}^{\mathrm{cL}}\left(\mathrm{q}^{\mathrm{L}}, \mathrm{q}^{\mathrm{H}}\right)-\lambda^{\mathrm{L}} \mathrm{F}\left(\mathrm{q}^{\mathrm{L}}\right) \text { and } \Pi^{\mathrm{H}}\left(\mathrm{q}^{\mathrm{L}}, \mathrm{q}^{\mathrm{H}}\right)=\mathrm{R}^{\mathrm{cH}}\left(\mathrm{q}^{\mathrm{L}}, \mathrm{q}^{\mathrm{H}}\right)-\lambda^{\mathrm{H}} \mathrm{F}\left(\mathrm{q}^{\mathrm{H}}\right) \text {, }
$$

where $\mathrm{R}^{\mathrm{cL}}\left(\mathrm{q}^{\mathrm{L}}, \mathrm{q}^{\mathrm{H}}\right)=\omega(\mathrm{r}) \mathrm{q}^{\mathrm{L}}$ and $\mathrm{R}^{\mathrm{cH}}\left(\mathrm{q}^{\mathrm{L}}, \mathrm{q}^{\mathrm{H}}\right)=\psi(\mathrm{r}) \mathrm{q}^{\mathrm{H}}$. Thus, the Nash equilibrium qualities, denoted $\mathrm{q}^{\mathrm{cL}}$ and $\mathrm{q}^{\mathrm{cH}}$, respectively satisfy the first order conditions:

$$
\Pi_{\mathrm{L}}^{\mathrm{L}}=\mathrm{R}_{\mathrm{L}^{-}}^{\mathrm{cL}} \lambda^{\mathrm{L}} \mathrm{F}^{\prime}\left(\mathrm{q}^{\mathrm{L}}\right)=0 \text { and } \Pi_{\mathrm{H}}^{\mathrm{H}}=\mathrm{R}_{\mathrm{H}}^{\mathrm{cH}}-\lambda^{\mathrm{H}} \mathrm{F}^{\prime}\left(\mathrm{q}^{\mathrm{H}}\right)=0 \text {. }
$$

In this Cournot case, marginal revenue with respect to own quality is always positive: i.e. from (25)

$$
\begin{aligned}
& \mathrm{R}_{\mathrm{L}}^{\mathrm{CL}}=\omega(\mathrm{r})-\mathrm{r} \omega^{\prime}(\mathrm{r})=(4 \mathrm{r}+1)(\mathrm{r})^{2} /(4 \mathrm{r}-1)^{3}>0 ; \\
& \mathrm{R}_{\mathrm{H}}^{\mathrm{cH}}=\psi(\mathrm{r})+\mathrm{r} \Psi^{\prime}(\mathrm{r})=\left(16(\mathrm{r})^{3}-12(\mathrm{r})^{2}+4 \mathrm{r}-1\right) /(4 \mathrm{r}-1)^{3}>0 .
\end{aligned}
$$

In considering the choice of qualities, there is again a tradeoff between competition affects arising from the extent of differentiation from the rival's product and the profitability of a particular location in quality space based on revenues and investment costs for a given quality ratio, r. Since firm $L$ gains from a narrowing of the quality gap, this gives firm $L$ an incentive to increase $\mathrm{q}^{\mathrm{L}}$, which reduces $r$, holding $\mathrm{q}^{\mathrm{H}}$ fixed (the term -r $\omega^{\prime}(\mathrm{r})$ in (29) is positive). For firm $\mathrm{H}$, analogously to Bertrand competition, a greater separation of products raises revenue leading it to also want to raise $\mathrm{q}^{\mathrm{H}}$. However, for both firm $\mathrm{L}$ and firm $\mathrm{H}$, the profitability of an increase in quality is limited by the rising marginal cost of investment in quality.

Although positive profits can be made at the second-stage Cournot equilibrium when $\mathrm{q}^{\mathrm{L}}=$ $\mathrm{q}^{\mathrm{H}}$, Lemma 3 shows (see Appendix B for the proof) that even if both firms face identical costs (i.e. if $\lambda^{\mathrm{L}}=\lambda^{\mathrm{H}}$ ), the first order conditions (28) imply that the quality game is asymmetric with $\mathrm{q}^{\mathrm{L}}<\mathrm{q}^{\mathrm{H}}$. and hence $r>1$.

Lemma 3. Assuming Cournot competition, if $\lambda^{L} \geq \lambda^{H}$, then $q^{L}<q^{H}$.

Letting $\mathrm{D}^{\mathrm{c}} \equiv \Pi_{\mathrm{LL}}^{\mathrm{L}} \Pi_{\mathrm{HH}}^{\mathrm{H}}-\Pi_{\mathrm{LH}}^{\mathrm{L}} \Pi_{\mathrm{HL}}^{\mathrm{H}}$, we require the second order and uniqueness conditions:

$$
\Pi_{\mathrm{LL}}^{\mathrm{L}}=\mathrm{R}_{\mathrm{LL}}^{\mathrm{cL}}-\lambda^{\mathrm{L}} \mathrm{F}^{\prime \prime}\left(\mathrm{q}^{\mathrm{L}}\right)<0, \Pi_{\mathrm{HH}}^{\mathrm{H}}=\mathrm{R}_{\mathrm{HH}}^{\mathrm{cH}}-\lambda^{\mathrm{H}} \mathrm{F}^{\prime \prime}\left(\mathrm{q}^{\mathrm{H}}\right)<0 \text { and } \mathrm{D}^{\mathrm{c}}>0 \text {. }
$$


For firm $\mathrm{H}$, we have $\mathrm{R}_{\mathrm{HH}}^{\mathrm{cH}}<0$ for $\mathrm{r}>1$. However, satisfaction of $\Pi_{\mathrm{LL}}^{\mathrm{L}}<0$ is made difficult by the fact that marginal revenue, $\mathrm{R}_{\mathrm{L}}^{\mathrm{cL}}$, increases as the products become more similar and hence $\mathrm{R}_{\mathrm{LL}}^{\mathrm{cL}}$ > 0: i.e. using $\omega^{\prime \prime}(\mathrm{r})=2(8 \mathrm{r}+1) /(4 \mathrm{r}-1)^{4}>0$ and $\mathrm{R}_{\mathrm{HH}}^{\mathrm{cH}}=\left(2 \psi^{\prime}(\mathrm{r})+\mathrm{r} \psi^{\prime \prime}(\mathrm{r})\right) / \mathrm{q}^{\mathrm{L}}$ for $\psi^{\prime \prime}(\mathrm{r})=-8(8 \mathrm{r}-5) /(4 \mathrm{r}-$ $1)^{4}<0$, we obtain:

$$
\mathrm{R}_{\mathrm{LL}}^{\mathrm{cL}}=(\mathrm{r})^{2} \omega^{\prime \prime}(\mathrm{r}) / \mathrm{q}^{\mathrm{L}}>0 ; \mathrm{R}_{\mathrm{HH}}^{\mathrm{cH}}=-8(\mathrm{r}-1) /(4 \mathrm{r}-1)^{4} \mathrm{q}^{\mathrm{L}}<0 .
$$

Lemma 4 (proved in Appendix B) concerns conditions under which (30) holds locally. For the case, $\mathrm{F}(\mathrm{q})=\mathrm{q}^{2} / 2$, commonly used in the literature ${ }^{21}$, we have $\mathrm{F}^{\prime \prime \prime}(\mathrm{q})=0$ and Lemma 4(i) applies for $\lambda^{\mathrm{L}} / \lambda^{\mathrm{H}} \geq 1$. Letting $\mathrm{E} \equiv \mathrm{qF}^{\prime \prime}(\mathrm{q}) / \mathrm{F}^{\prime}(\mathrm{q})$ represent the responsiveness (or elasticity) of the marginal $\operatorname{cost} \mathrm{F}^{\prime}(\mathrm{q})$ of investment with respect to quality, since $\mathrm{F}^{\prime}(0)=0$, the assumption $\mathrm{F}^{\prime \prime \prime}(\mathrm{q}) \geq 0$ (see (1)) ensures $F^{\prime \prime}(q) \geq F^{\prime}(q) / q$ and hence $E \geq 1$. If $E=1$ then $F^{\prime \prime \prime}(q)=0$ and Lemma 4(i) applies. However, to allow for more general investment cost functions and for any value of $\lambda^{\mathrm{L}} / \lambda^{\mathrm{H}}$, Lemma 4(ii) requires that firm L's marginal cost of investment increases more steeply: i.e. for $q^{\mathrm{L}}$ satisfying $\Pi^{\mathrm{L}}$ $=0$, that $\mathrm{E}^{\mathrm{L}} \equiv \mathrm{q}^{\mathrm{L}} \mathrm{F}^{\prime \prime}\left(\mathrm{q}^{\mathrm{L}}\right) / \mathrm{F}^{\prime}\left(\mathrm{q}^{\mathrm{L}}\right) \geq 2$. For the example ${ }^{22}, \mathrm{~F}(\mathrm{q})=\mathrm{aq}^{\mathrm{n}}, \mathrm{E}=\mathrm{n}-1$ is a constant and Lemma 4(ii) applies if $n \geq 3$.

Lemma 4. Assume Cournot competition and conditions (1). Then $\Pi_{L L}^{L}<0, \Pi_{H H}^{H}<0$ and $D^{c} \equiv$ $\Pi \Pi_{L L} \Pi_{H H}^{H}-\Pi_{L H} \Pi_{H L}^{H}>0$ are satisfied at $\Pi_{L}^{L}=0:$ (i) if $\Pi_{H}^{H}=0, F^{\prime \prime \prime}(q)=0$ and $\lambda^{L} / \lambda^{H} \geq 1$ or (ii) if $E^{L} \geq 2$.

Firm $\mathrm{H}$ continues to view $\mathrm{q}^{\mathrm{L}}$ as a strategic complement to $\mathrm{q}^{\mathrm{H}}$, but since $\mathrm{R}_{\mathrm{L}}^{\mathrm{cL}}$ is increased by a greater similarity of products, it follows that $\mathrm{R}_{\mathrm{LH}}^{\mathrm{CL}}<0$ and hence that firm $\mathrm{L}$ views $\mathrm{q}^{\mathrm{H}}$ as a strategic substitute to $\mathrm{q}^{\mathrm{L}}$ : i.e. from (29) and (31),

\footnotetext{
${ }^{21}$ See Motta (1993) and Herguera, Kujal and Petrakis (1999). The proof of Lemma 4 has the advantage that it does not require a numerical solution for $\mathrm{r}=\mathrm{q}^{\mathrm{H}} / \mathrm{q}^{\mathrm{L}}$.

${ }^{22}$ For $\mathrm{F}(\mathrm{q})=\mathrm{q}\left(\mathrm{e}^{\mathrm{aq}}-1\right)$, using $\mathrm{e}^{\mathrm{aq}}>1$ and $\mathrm{R}_{\mathrm{L}}^{\mathrm{cL}}=\lambda^{\mathrm{L}} \mathrm{F}^{\prime}\left(\mathrm{q}^{\mathrm{L}}\right)>5 / 27$ at $\mathrm{r}=1$, we obtain $\mathrm{E}^{\mathrm{L}}>\mathrm{aq}{ }^{\mathrm{L}}\left[1+10 \lambda^{\mathrm{L}} / 27\right]>$ 2 for suitable parameter values.
} 


$$
\Pi_{\mathrm{LH}}^{\mathrm{L}}=\mathrm{R}_{\mathrm{LH}}^{\mathrm{cL}}=-\mathrm{R}_{\mathrm{LL}}^{\mathrm{cL}} / \mathrm{r}<0 \text { and } \Pi_{\mathrm{HL}}^{\mathrm{H}}=\mathrm{R}_{\mathrm{HL}}^{\mathrm{cH}}=-\mathrm{rR}_{\mathrm{HH}}^{\mathrm{cH}}>0 \text {. }
$$

Thus, as shown in Figure 4, firm L's reaction function, $\mathrm{q}^{\mathrm{L}}=\rho^{\mathrm{cL}}\left(\mathrm{q}^{\mathrm{H}}\right)$, is negatively sloped in the neighborhood of equilibrium ${ }^{23}$, whereas $\mathrm{q}^{\mathrm{H}}=\rho^{\mathrm{cH}}\left(\mathrm{q}^{\mathrm{L}}\right)$ has a positive slope; i.e. from (28), (32) and Lemma 4,

$$
\mathrm{dq} / \mathrm{dq}^{\mathrm{H}}=-\mathrm{R}_{\mathrm{LH}}^{\mathrm{cL}} / \Pi_{\mathrm{LL}}^{\mathrm{L}}<0 \text { and } \mathrm{dq}^{\mathrm{H}} / \mathrm{dq}^{\mathrm{L}}=-\mathrm{R}_{\mathrm{HL}^{\mathrm{CH}}}^{\mathrm{cH}} / \Pi_{\mathrm{HH}}^{\mathrm{H}}>0 \text {. }
$$

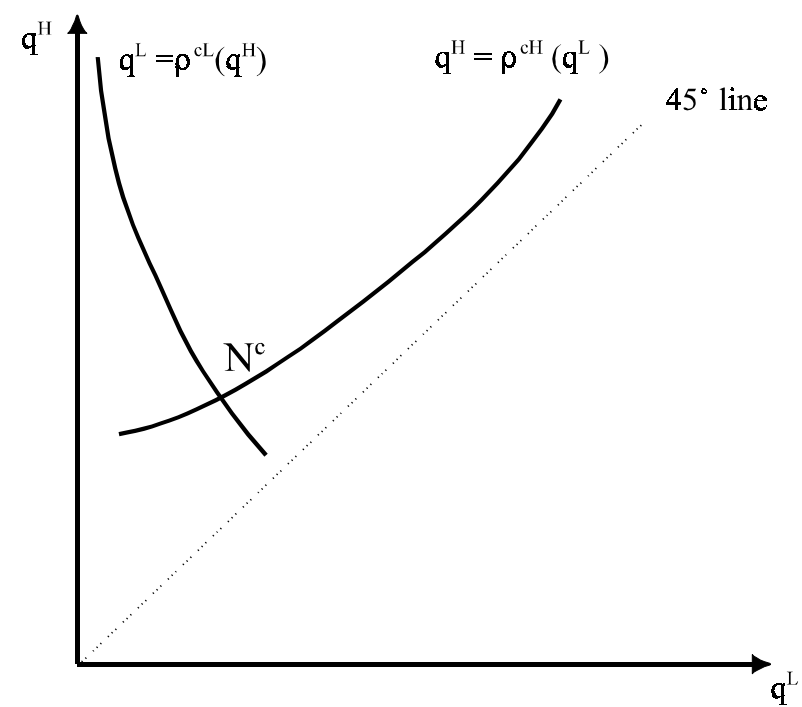

Figure 4 Quality reaction functions: Cournot competition

Analogously to Proposition 1 for Bertrand competition, for a sufficiently large cost disadvantage in the LDC, we are able to prove existence and uniqueness of the pure strategy equilibrium (see Appendix B for the proof) in which the LDC firm produces $\mathrm{q}^{\mathrm{L}}$ and the developed country firm produces $\mathrm{q}^{\mathrm{H}}$. For the remainder of the paper we assume that Proposition 9 applies and hence $\lambda^{\mathrm{L}}=\gamma\left(1-\mathrm{s}^{\mathrm{L}}\right)$ and $\lambda^{\mathrm{H}}=1-\mathrm{s}^{\mathrm{H}}$ where $\mathrm{s}^{\mathrm{L}}$ and $\mathrm{s}^{\mathrm{H}}$ represent the investment subsidy policies by LDC and developed countries respectively.

Proposition 9. Assume Cournot competition in the output market. Under conditions (1), if $\gamma \geq 1$ is sufficiently large, there exists a unique pure strategy equilibrium in which the low quality product

\footnotetext{
${ }^{23}$ Since Lemma 4(ii) requires $\Pi_{\mathrm{L}}^{\mathrm{L}}=0$, but not $\Pi_{\mathrm{H}}^{\mathrm{H}}=0$, it follows that if $\mathrm{E} \geq 2$, then $\Pi^{\mathrm{L}}{ }_{\mathrm{LL}}<0$ along firm L's reaction function.
} 
is produced in the LDC and the high quality product in the developed country.

4.2 LDC investment policy towards the low-quality product.

For the Cournot setting, the effects of an investment subsidy, $\mathrm{s}^{\mathrm{L}}$, applied to firm $\mathrm{L}$ by the LDC on quality levels and profits are presented in Proposition 10.

Proposition 10. Under Cournot competition, an increase in the investment subsidy, $s^{L}$, by the LDC: (a) raises both $q^{L}$ and $q^{H}$, but $r=q^{H} / q^{L}$ falls, making the products closer substitutes.

(b) increases profit $\Pi^{L}$ of firm $L$ and reduces profit $\Pi^{H}$.

Proof. (a) From (B.5) in Appendix B and $\lambda^{\mathrm{L}}=\gamma\left(1-\mathrm{s}^{\mathrm{L}}\right)$, we obtain $\mathrm{dq} / \mathrm{ds} s^{\mathrm{L}}=-\gamma \mathrm{F}^{\prime}\left(\mathrm{q}^{\mathrm{L}}\right) \Pi_{{ }_{\mathrm{HH}}}^{\mathrm{H}} / \mathrm{D}^{\mathrm{c}}>0$, $\mathrm{dq}^{\mathrm{H}} / \mathrm{ds}^{\mathrm{L}}=\gamma \mathrm{F}^{\prime}\left(\mathrm{q}^{\mathrm{L}}\right) \mathrm{R}_{\mathrm{HL}}^{\mathrm{cH}} / \mathrm{D}^{\mathrm{c}}>0$ and, analogously to (19), $\mathrm{dr} / \mathrm{ds}^{\mathrm{L}}=-\mathrm{r} \lambda^{\mathrm{H}} \gamma \mathrm{F}^{\prime}\left(\mathrm{q}^{\mathrm{L}}\right) \mathrm{F}^{\prime \prime}\left(\mathrm{q}^{\mathrm{H}}\right) / \mathrm{D}^{\mathrm{c}} \mathrm{q}^{\mathrm{L}}<0$. (b) From (27), using $\Pi^{\mathrm{H}}{ }_{\mathrm{H}}=0, \lambda^{\mathrm{L}}=\gamma\left(1-\mathrm{s}^{\mathrm{L}}\right)$ and $\mathrm{R}_{\mathrm{L}}^{\mathrm{cH}}<0$, we obtain $\mathrm{d} \Pi^{\mathrm{H}} / \mathrm{ds}^{\mathrm{L}}=\mathrm{R}_{\mathrm{L}}^{\mathrm{cH}}\left(\mathrm{dq}^{\mathrm{L}} / \mathrm{ds}^{\mathrm{L}}\right)<0$. Since $\mathrm{d} \Pi^{\mathrm{L}} / \mathrm{d} \lambda^{\mathrm{L}}<0$ from Lemma 5 (see Appendix B) and $\lambda^{\mathrm{L}}=\gamma\left(1-\mathrm{s}^{\mathrm{L}}\right)$, we also obtain $\mathrm{d} \Pi^{\mathrm{L}} / \mathrm{ds}^{\mathrm{L}}=$ $\mathrm{R}^{\mathrm{cL}}{ }_{\mathrm{H}}\left(\mathrm{dq}^{\mathrm{H}} / \mathrm{ds}^{\mathrm{L}}\right)+\gamma \mathrm{F}\left(\mathrm{q}^{\mathrm{L}}\right)>0$.

Interestingly, comparing Proposition 10 with Proposition 2 for Bertrand competition, the direction of effects is the same. However, there are some critical differences behind the scenes, since, as shown in Proposition 11, the LDC has a unilateral incentive to tax the investment of its firm under Cournot competition, whereas a subsidy raises LDC welfare in the Bertrand case. For Proposition 11, we assume that LDC welfare, denoted $\mathrm{W}^{\mathrm{cL}} \equiv \Pi^{\mathrm{L}}\left(\mathrm{q}^{\mathrm{L}}, \mathrm{q}^{\mathrm{H}}, \lambda^{\mathrm{L}}\right)-\mathrm{s}^{\mathrm{L}} \gamma \mathrm{F}\left(\mathrm{q}^{\mathrm{L}}\right)$, is locally concave at the optimal policy, $\mathrm{s}^{\mathrm{cL} *}$. As shown in Lemma 6 of Appendix B, this holds for ${ }^{24}$ :

$$
\mathrm{E}^{\mathrm{L}} \equiv \mathrm{q}^{\mathrm{L}} \mathrm{F}^{\prime \prime}\left(\mathrm{q}^{\mathrm{L}}\right) / \mathrm{F}^{\prime}\left(\mathrm{q}^{\mathrm{L}}\right) \geq 2 \text { and } \sigma(\mathrm{q}) \equiv\left(\mathrm{F}^{\prime \prime}(\mathrm{q})\right)^{2}-\mathrm{F}^{\prime}(\mathrm{q}) \mathrm{F}^{\prime \prime \prime}(\mathrm{q}) \geq 0 .
$$

Proposition 11. Under Cournot competition, the LDC has an incentive to tax investment in $q^{L}$.

Proof. Assume $\mathrm{d}^{2} \mathrm{~W}^{\mathrm{cL}} /\left(\mathrm{ds}^{\mathrm{L}}\right)^{2}<0$ at $\mathrm{s}^{\mathrm{L} *}$. Using $\mathrm{d} \Pi^{\mathrm{L}} / \mathrm{ds}^{\mathrm{L}}=\mathrm{R}^{\mathrm{cL}}{ }_{\mathrm{H}}\left(\mathrm{dq}^{\mathrm{H}} / \mathrm{ds}^{\mathrm{L}}\right)+\gamma \mathrm{F}\left(\mathrm{q}^{\mathrm{L}}\right)$, we obtain $\mathrm{dW}^{\mathrm{cL}} / \mathrm{ds}^{\mathrm{L}}$

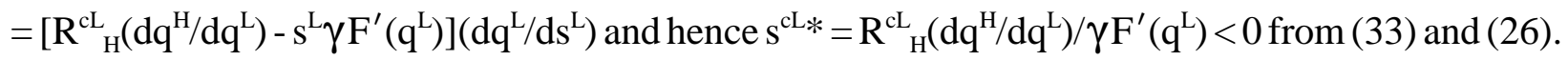

\footnotetext{
${ }^{24}$ We have $\sigma(q)>0$ if $F(q)=a q^{n}$ for $n \geq 2$ or if $F(q)=q\left(e^{a q}-1\right)$.
} 
This tax policy may initially seem hard to understand, since, as can be seen from Proposition 10, the LDC tax lowers the profit of firm $\mathrm{L}$ and at the same time, since firm $\mathrm{H}$ benefits from a reduction in $\mathrm{q}^{\mathrm{L}}$, raises the profit of firm $\mathrm{H}$ and hence welfare in the developed country. However, LDC welfare rises because the tax revenue more than offsets the loss in firm L's profit. Also, the fact that firm H's profits are increased simply means that the rent-shifting aspect of the policy is entirely at the expense of consumers in the third country market. As illustrated in Figure 5, the LDC tax shifts the quality reaction function of firm $\mathrm{L}$ in towards the origin (shown by the dashed line) and both countries move to higher iso-welfare contours.

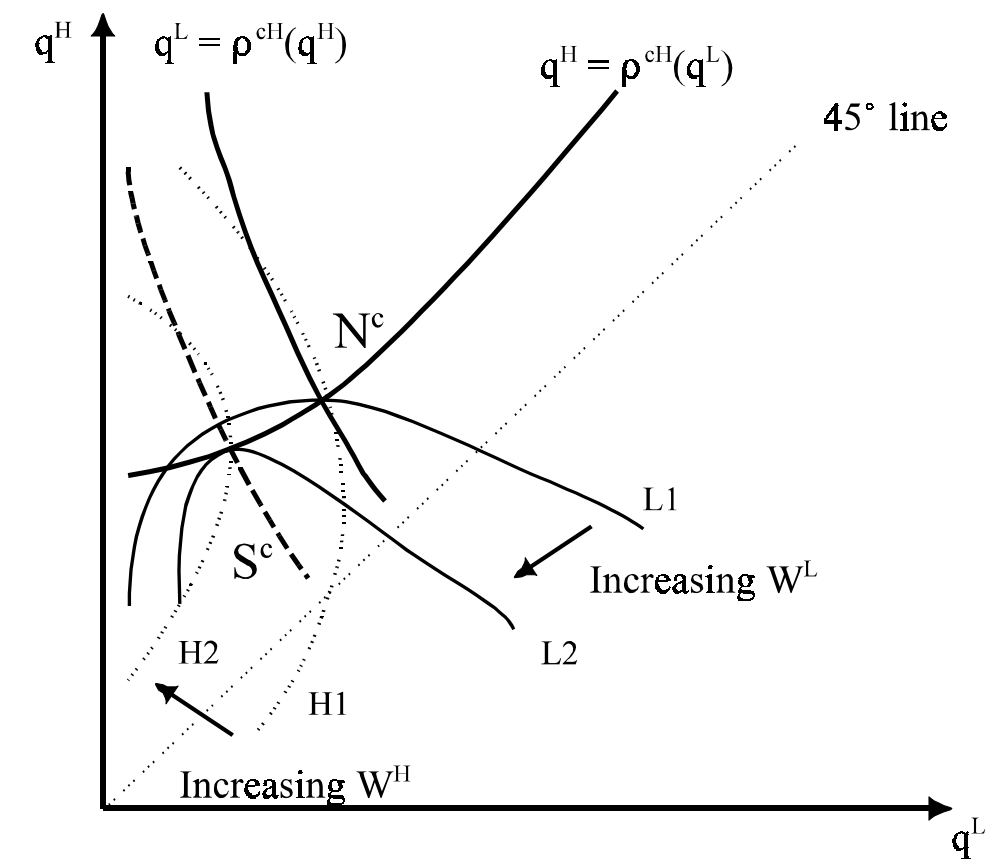

Figure 5 The LDC's optimal tax: Cournot competition

To understand why a switch from Bertrand to Cournot competition causes LDC policy to switch from an investment subsidy to an investment tax, we again appeal to the correspondence of the model with a Stackelberg leader-follower model in which firm L is the leader and there is no government intervention. Since firm $\mathrm{H}$ raises $\mathrm{q}^{\mathrm{H}}$ in response to an increase in $\mathrm{q}^{\mathrm{L}}$ under both Bertrand 
and Cournot competition, the fact that the revenues of firm $\mathrm{L}$ are increased by an increase in $\mathrm{q}^{\mathrm{H}}$ under Bertrand competition (i.e. $\mathrm{R}_{\mathrm{H}}^{\mathrm{L}}>0$ ) and are reduced by an increase in $\mathrm{q}^{\mathrm{H}}$ under Cournot competition (i.e. $\mathrm{R}_{\mathrm{H}}^{\mathrm{cL}}<0$ ), means that a Stackelberg leader would increase $\mathrm{q}^{\mathrm{L}}$ above its Nash equilibrium value in the Bertrand case and reduce $\mathrm{q}^{\mathrm{L}}$ in the Cournot case $\mathrm{e}^{25}$. If both firms play Nash in quality, the same outcome is achieved by an investment subsidy in the LDC under Bertrand competition and an investment tax under Cournot competition.

Fundamentally, by taking $\mathrm{q}^{\mathrm{H}}$ as given at the Nash quality equilibrium, firm $\mathrm{L}$ overestimates the effect of an increase in $\mathrm{q}^{\mathrm{L}}$ in making the products more similar under both forms of competition. However, since firm L gains from a greater separation of products in the Bertrand case and from a greater similarity of products in the Cournot case, it sets $\mathrm{q}^{\mathrm{L}}$ too low in the Bertrand case and too high in the Cournot case for maximum profit. To correct for this, the LDC policy moves firm L (and hence firm H) up the quality ladder under Bertrand competition and down the quality ladder under Cournot competition.

\subsection{Developed country policy towards the high-quality product}

For the Cournot setting, Proposition 12 concerns the effects of an investment subsidy, $\mathrm{s}^{\mathrm{H}}$, applied to firm $\mathrm{H}$ by the developed country. An increase in $\mathrm{s}^{\mathrm{H}}$ increases quality $\mathrm{q}^{\mathrm{H}}$, but in contrast to the Bertrand setting, firm L's reaction function has a negative slope and $\mathrm{q}^{\mathrm{L}}$ falls. As might be expected, Firm H enjoys higher profits, but firm L's profits are reduced.

Proposition 12. Under Cournot competition, an increase in the investment subsidy, $s^{H}$, to firm $H$ : (a) raises $q^{H}$ but reduces $q^{L}$, causing $r=q^{H} / q^{L}$ to rise. (b) increases profit $\pi^{H}$, but reduces $\pi^{L}$.

Proof. (a). From (B.5) in Appendix B and $\lambda^{\mathrm{H}}=1-\mathrm{s}^{\mathrm{H}}$, we obtain $\mathrm{dq} / \mathrm{H} / \mathrm{ds}^{\mathrm{H}}=-\mathrm{F}^{\prime}\left(\mathrm{q}^{\mathrm{H}}\right) \Pi^{\mathrm{L}}{ }_{\mathrm{LL}} / \mathrm{D}^{\mathrm{c}}>0$ and $\mathrm{dq} / \mathrm{ds}^{\mathrm{H}}=\mathrm{F}^{\prime}\left(\mathrm{q}^{\mathrm{H}}\right) \mathrm{R}_{\mathrm{LH}}^{\mathrm{cL}} / \mathrm{D}^{\mathrm{c}}<0$. Using $\mathrm{dr} / \mathrm{dq}^{\mathrm{H}}=-\lambda^{\mathrm{L}} \gamma \mathrm{F}^{\prime \prime}\left(\mathrm{q}^{\mathrm{L}}\right) / \Pi_{\mathrm{LL}}^{\mathrm{L}}>0$, we then obtain $\mathrm{dr} / \mathrm{ds}^{\mathrm{H}}>0$. (b).

\footnotetext{
${ }^{25}$ More formally, for Cournot competition, $\mathrm{d} \Pi \frac{\mathrm{L}}{\mathrm{dq}^{\mathrm{L}}}=\Pi_{\mathrm{L}}^{\mathrm{L}}+\mathrm{R}_{\mathrm{H}}^{\mathrm{cL}}\left(\mathrm{dq}^{\mathrm{H}} / \mathrm{dq}^{\mathrm{L}}\right)<0$ at $\Pi^{\mathrm{L}}{ }_{\mathrm{L}}=0$.
} 
From (27) using $\Pi_{\mathrm{L}}^{\mathrm{L}}=\Pi_{\mathrm{H}}^{\mathrm{H}}=0, \lambda^{\mathrm{H}}=1-\mathrm{s}^{\mathrm{H}}, \mathrm{R}_{\mathrm{H}}^{\mathrm{cL}}<0, \mathrm{R}_{\mathrm{L}}^{\mathrm{cH}}<0$ and part(a), we obtain $\mathrm{d} \Pi^{\mathrm{H}} / \mathrm{ds}^{\mathrm{H}}=$ $\mathrm{R}_{\mathrm{L}}^{\mathrm{cH}}\left(\mathrm{dq} / \mathrm{ds} s^{\mathrm{H}}\right)+\mathrm{F}\left(\mathrm{q}^{\mathrm{H}}\right)>0$ and $\mathrm{d} \Pi^{\mathrm{L}} / \mathrm{ds}^{\mathrm{H}}=\mathrm{R}_{\mathrm{H}}^{\mathrm{cL}}\left(\mathrm{dq}^{\mathrm{H}} / \mathrm{ds}^{\mathrm{H}}\right)<0$.

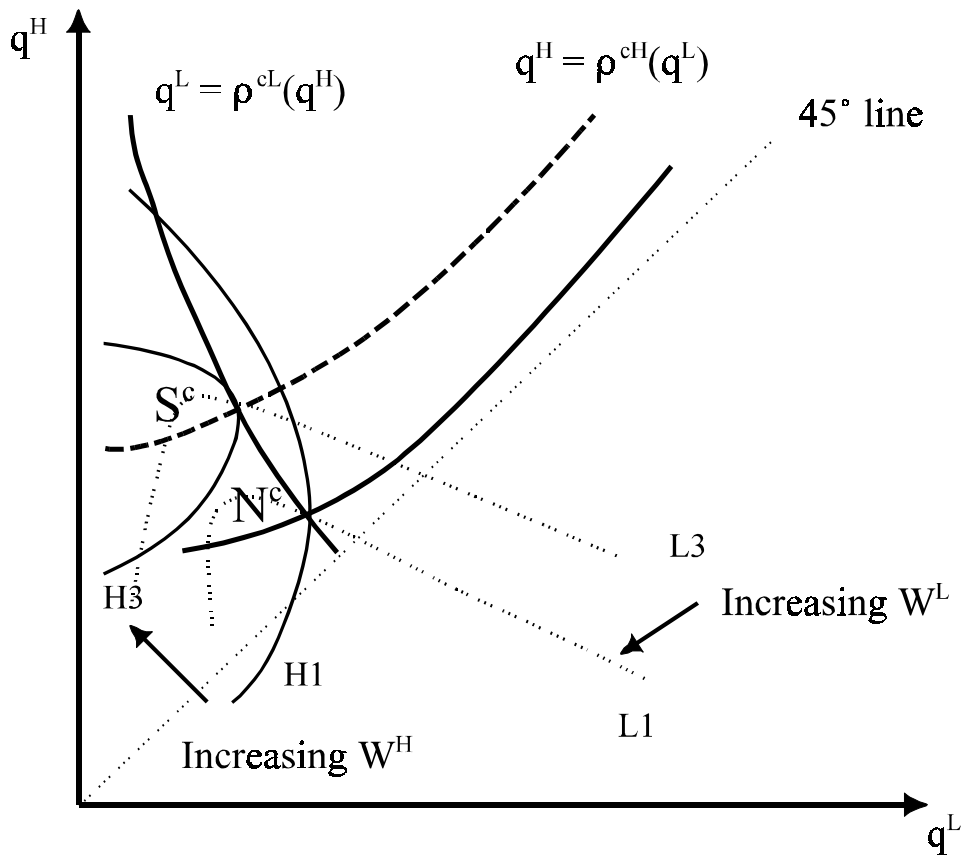

Figure 6. The developed country's optimal subsidy: Cournot competition

Next, Proposition 13 shows that a shift form Bertrand to Cournot competition gives country $\mathrm{H}$ an incentive to subsidize rather than tax the investment of its firm. As illustrated in Figure 6, under Cournot competition, the subsidy shifts up the quality reaction function of firm $\mathrm{H}$ (shown as the dashed line), moving the equilibrium from point $\mathrm{N}^{\mathrm{c}}$ to point $\mathrm{S}^{\mathrm{c}}$, which, as before, corresponds to the Stackelberg leader-follower point with firm $\mathrm{H}$ as the leader and $\mathrm{s}^{\mathrm{cH}}=0$. Since firm $\mathrm{H}$ gains from a reduction in $\mathrm{q}^{\mathrm{L}}$ under both forms of competition (i.e. $\mathrm{R}_{\mathrm{L}}^{\mathrm{cH}}<0$ and $\mathrm{R}_{\mathrm{L}}^{\mathrm{cH}}<0$ ), in each case the policy is aimed at reducing $\mathrm{q}^{\mathrm{L}}$. For Cournot competition, it follows from the negative slope of firm L's reaction function that a subsidy will raise $\mathrm{q}^{\mathrm{H}}$ and hence lower $\mathrm{q}^{\mathrm{L}}$. By contrast, in the Bertrand case, since firm $\mathrm{L}$ raises $\mathrm{q}^{\mathrm{L}}$ in response to an increase in $\mathrm{q}^{\mathrm{H}}$, the relevant policy is an investment tax. For Proposition 13, we assume that the welfare function, $\mathrm{W}^{\mathrm{cH}}$, for country $\mathrm{H}$ is locally concave at the optimum subsidy, $\mathrm{s}^{\mathrm{cH} *}$. From Lemma 7 (see Appendix B for the proof), this holds under the same 
conditions, $\mathrm{E}^{\mathrm{L}} \geq 2$ and $\sigma(\mathrm{q}) \geq 0$, used to ensure local concavity of LDC welfare.

Lemma 7: Assume Cournot competition and conditions (1). Sufficient conditions to ensure local concavity offirm H's profit as a Stackelberg leader in quality space or equivalently, local concavity of $W^{c H}$ with respect to $s^{H}$ are $E^{L} \equiv q^{L} F^{\prime \prime}\left(q^{L}\right) / F^{\prime}\left(q^{L}\right) \geq 2$ and $\sigma \equiv\left(F^{\prime \prime}(q)\right)^{2}-F^{\prime}(q) F^{\prime \prime \prime}(q) \geq 0$.

Proposition 13. Under Cournot competition, country $H$ gains from a subsidy to investment in $q^{H}$. Proof: Similar to Proposition 6, using (26) and (33), we obtain $\mathrm{s}^{\mathrm{cH} *}=\mathrm{R}_{\mathrm{L}}^{\mathrm{cH}}\left(\mathrm{dq}^{\mathrm{L}} / \mathrm{dq}^{\mathrm{H}}\right) / \mathrm{F}^{\prime}\left(\mathrm{q}^{\mathrm{H}}\right)>0$.

Finally, as in the Bertrand case, the jointly optimal investment policy corrects for the cross effects of the quality chosen by each firm on its rival's profit. Since Firm H gains from the widening of the quality gap due to a reduction in $\mathrm{q}^{\mathrm{L}}$ and firm $\mathrm{L}$ gains from the narrowing of the quality gap due to a reduction in $\mathrm{q}^{\mathrm{H}}$, joint profit maximization involves a move by both firms down the quality ladder. Consequently, as shown in Proposition 14, the policy requires that each country tax investment, with the tax given by $\mathrm{s}^{\mathrm{LJ}}=\mathrm{R}_{\mathrm{L}}^{\mathrm{cH}} / \gamma \mathrm{F}^{\prime}\left(\mathrm{q}^{\mathrm{L}}\right)<0$ in the $\mathrm{LDC}$ and $\mathrm{s}^{\mathrm{HJ}}=\mathrm{R}_{\mathrm{H}}^{\mathrm{cL}} / \mathrm{F}^{\prime}\left(\mathrm{q}^{\mathrm{H}}\right)<0$ in country H. Relative to the Nash policy equilibrium, the joint choice of policies increases the investment tax in the LDC and results in a switch from a subsidy to a tax in the developed country. Since an increase in product differentiation has mixed effects on price competition $\left(\mathrm{p}^{\mathrm{H}}\right.$ rises and $\mathrm{p}^{\mathrm{L}}$ falls), in contrast to the Bertrand case, there is no clear relationship between the size of the quality gap and the ability to raise prices at the expense of third country consumers. Rather the jointly optimal policy is directed at finding the optimal location in quality space taking into account revenues and the increasingly high investment costs as quality is increased.

Proposition 14. Under Cournot competition, the joint welfare of the two producing countries is maximized by an investment tax in both countries with $s^{c L J}<s^{c L^{*}}<0$ and $s^{c H J}<0<s^{c H *}$.

\section{Conclusion}

This paper develops the implications of strategic trade theory for policies targeted at the quality of exports. The model involves a three-stage game in which an LDC and a developed country 
attempt to reposition their firms in product quality space through taxes and subsidies on investment. The two firms (one in each country) first make an investment determining the quality of their product and then compete on the basis of either Bertrand or Cournot competition in a third country export market. An important innovation is our consideration of asymmetric costs of investment in quality with the LDC firm potentially facing substantially higher costs. If this cost difference is sufficiently large, we show that there exists a unique pure strategy equilibrium in which the LDC firm (firm L) produces the low-quality product and the developed country firm (firm H) produces the high-quality product. The paper also makes a technical contribution by providing analytical proofs of concavity for the profit and welfare functions under specified conditions.

There are two basic considerations in determining the profitability of a particular location on the quality ladder. First, for a given difference between own quality and the quality of the rival firm, there is the profitability of the location based on revenue and the investment costs required to reach that quality. Higher quality products tend to command higher revenues, but this tends to be offset by the fact that the cost of investment in quality is increasing at an increasing rate. The second consideration is the extent of the gap between own quality and the quality of the rival firm, but the role played by this gap differs depending on the nature of product market competition. Under Bertrand competition, an increase in the quality gap or extent of differentiation of the products relaxes price competition, raising the profits of both firms, whereas under Cournot competition, the effect on profits depends on whether the firm is above or below its rival on the quality ladder. Under Cournot competition, firm H's profit is increased by a reduction in the quality of firm L as before, but firm $\mathrm{H}$ responds to an increase in its own quality by sufficiently increasing output so as to cause firm L's profits to fall. This difference in responses is at the heart of the explanation for the opposing policy prescriptions arising under the two market structures.

For the LDC, strategic trade policy involves a subsidy to investment in quality under Bertrand 
competition and a tax under Cournot competition. At the Nash equilibrium in qualities, each firm takes its rival's quality as fixed, but under both Bertrand and Cournot competition, firm $\mathrm{H}$ responds to an increase in LDC quality by also increasing quality so as to partially offset the narrowing of the quality gap. As a result, firm L in the LDC overestimates the extent to which the quality gap will narrow as it raises its quality. In the Bertrand case, since LDC profits are increasing in the quality gap, this causes firm L to position its product too low on the quality ladder. By contrast, in the Cournot case, firm L is better off as the quality gap narrows and it sets too high a quality. As is typical in strategic trade policy models, the government can increase domestic welfare by committing to its policy so as to shift the equilibrium to what would have been the outcome if the domestic firm could act as a Stackelberg leader in the absence of policy. Taking into account the reaction of the high quality firm, optimal LDC policy then involves an investment subsidy so as to move firm L (and hence firm $\mathrm{H}$ ) up the quality ladder in the Bertrand case and an investment tax so as to move firm $\mathrm{L}$ (and firm $\mathrm{H}$ ) down the quality ladder in the Cournot case. Under Bertrand competition, the subsidy actually causes a narrowing of the quality gap, which hurts the profits of both firms by sharpening price competition. However, the increased LDC revenue from the improvement in quality more than offsets this. Similarly, the LDC gain from a move down the quality ladder under Cournot competition more than offsets the loss from the widening in the quality gap due to the tax policy.

Similar reasoning applies with respect to developed country policy, except that now the direction of incentives under the two forms of competition is changed. Thus the developed country has an incentive to tax investment in quality under Bertrand competition and to subsidize investment in quality under Cournot competition. One factor explaining this switch in policy is that the direction of the LDC firm's response to an increase firm H's quality depends on the nature of competition. Thus the LDC firm responds by increasing its quality under Bertrand competition, but by reducing its quality under Cournot competition. It follows that at the Nash equilibrium in qualities, firm $\mathrm{H}$ in 
the developed country overestimates the extent to which the quality gap will widen as it raises its quality in the Bertrand case, but underestimates the widening of the gap in the Cournot case. Since firm $\mathrm{H}$ gains from a widening of the quality gap under both forms of competition, it sets too high a quality in the Bertrand case (explaining the investment tax) and too low a quality (explaining the investment subsidy) in the Cournot case.

We also consider the possibility that both producing countries coordinate their policies so as to maximize joint profits at the expense of consumers in the third country. These joint policies correct for the fact that the Nash equilibrium qualities do not take into account effects on the rival's profit. A coordinated strategy under Bertrand competition involves an increase in differentiation as a means of reducing price competition. Thus the LDC would tax its firm while the developed country would subsidize its firm. Under Cournot competition, since each firm gains from a move of its rival down the quality ladder (narrowing the quality gap for firm L and widening it for firm $\mathrm{H}$ ), both governments tax quality.

This paper has focused on strategic trade theory as a motive for policies aimed at the quality of exports. It is not hard to find alternative motives for policies directed at improving the quality of low quality exports, such as an effort by a government to reduce externalities that may damage its "country of origin" brand reputation, or as a means of allowing "infant industries" to catch up with world market standards. However, in addition to providing a further explanation for such policies, strategic trade theory can also help explain less intuitively obvious policies, such as attempts by governments to subsidize quality improvement in industries which are already global leaders in quality (e.g. Finland in paper and Canada in newsprint). Strategic trade policy also suggests circumstances in which governments with low quality sectors might want to encourage producers to remain in that niche of production rather than improve their quality (as was the case with Korea's “Northern Strategy"). 


\section{Appendix A: Bertrand Competition}

Letting $\mathrm{q}^{\mathrm{L}}=\mathrm{q}^{\mathrm{L}}\left(\lambda^{\mathrm{L}}, \lambda^{\mathrm{H}}\right)$ and $\mathrm{q}^{\mathrm{H}}=\mathrm{q}^{\mathrm{H}}\left(\lambda^{\mathrm{L}}, \lambda^{\mathrm{H}}\right)$ denote the Nash quality levels, totally differentiating the first order conditions $\pi_{\mathrm{L}}^{\mathrm{L}}=0$ and $\pi_{\mathrm{H}}^{\mathrm{H}}=0$ (from (13)) and applying Cramer's rule, we obtain:

$$
\begin{aligned}
& \mathrm{dq} / \mathrm{d} \lambda^{\mathrm{L}}=\mathrm{F}^{\prime}\left(\mathrm{q}^{\mathrm{L}}\right) \pi_{\mathrm{HH}}^{\mathrm{H}} / \mathrm{D}<0, \mathrm{dq}^{\mathrm{H}} / \mathrm{d} \lambda^{\mathrm{L}}=-\mathrm{F}^{\prime}\left(\mathrm{q}^{\mathrm{L}}\right) \mathrm{R}^{\mathrm{H}}{ }_{\mathrm{HL}} / \mathrm{D}<0 ; \\
& \mathrm{dq}^{\mathrm{H}} / \mathrm{d} \lambda^{\mathrm{H}}=\mathrm{F}^{\prime}\left(\mathrm{q}^{\mathrm{H}}\right) \pi_{\mathrm{LL}}^{\mathrm{L}} / \mathrm{D}<0, \mathrm{dq}^{\mathrm{L}} / \mathrm{d}^{\mathrm{H}}=-\mathrm{F}^{\prime}\left(\mathrm{q}^{\mathrm{H}}\right) \mathrm{R}_{\mathrm{LH}}^{\mathrm{L}} / \mathrm{D}<0,
\end{aligned}
$$

where $\mathrm{D} \equiv \pi^{\mathrm{L}}{ }_{\mathrm{LL}} \pi_{\mathrm{HH}}^{\mathrm{H}}-\pi^{\mathrm{L}}{ }_{\mathrm{LH}} \pi_{\mathrm{HL}}^{\mathrm{H}}>0$ from (16). If firms 1 and 2 produce the low and high quality products respectively (as we show in Proposition 1), this implies $\lambda^{\mathrm{L}}=\left(1-\mathrm{s}^{\mathrm{L}}\right) \gamma$ and $\lambda^{\mathrm{H}}=1-\mathrm{s}^{\mathrm{H}}$ where $\mathrm{s}^{\mathrm{L}}$ is the subsidy set by the LDC and $\mathrm{s}^{\mathrm{H}}$ is the subsidy set by the developed country

Lemma 1 is used for the proofs of both Propositions 1 and 5.

Lemma 1. Under conditions (1), $d \pi^{H} / d \lambda^{H}<0$.

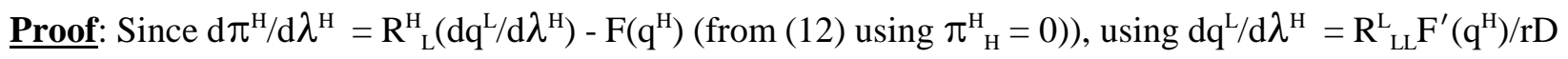
$<0$ (from (A.1) and $\mathrm{R}_{\mathrm{LH}}^{\mathrm{L}}=-\mathrm{R}_{\mathrm{LL}}^{\mathrm{L}} / \mathrm{r}$ ), we obtain $\mathrm{d} \pi^{\mathrm{H}} / \mathrm{d} \lambda^{\mathrm{H}}=\left[\mathrm{R}_{\mathrm{L}}^{\mathrm{H}} \mathrm{R}_{\mathrm{LL}}^{\mathrm{L}} \mathrm{F}^{\prime}\left(\mathrm{q}^{\mathrm{H}}\right)-\mathrm{rDF}\left(\mathrm{q}^{\mathrm{H}}\right)\right] / \mathrm{rD}$. Using $\mathrm{D}$ as in (16) and letting $\mathrm{Z} \equiv \mathrm{R}_{\mathrm{L}}^{\mathrm{H}} \mathrm{F}^{\prime}\left(\mathrm{q}^{\mathrm{H}}\right)+\mathrm{r} \lambda^{\mathrm{H}} \mathrm{F}^{\prime \prime}\left(\mathrm{q}^{\mathrm{H}}\right) \mathrm{F}\left(\mathrm{q}^{\mathrm{H}}\right)$, this implies:

$$
\mathrm{d} \pi^{\mathrm{H}} / \mathrm{d} \lambda^{\mathrm{H}}=\mathrm{R}_{\mathrm{LL}}^{\mathrm{L}} \mathrm{Z} / \mathrm{rD}+\lambda^{\mathrm{L}} \mathrm{F}^{\prime \prime}\left(\mathrm{q}^{\mathrm{L}}\right) \mathrm{F}\left(\mathrm{q}^{\mathrm{H}}\right) \pi_{\mathrm{HH}}^{\mathrm{H}} / \mathrm{D} \text {. }
$$

Since $\pi_{H H}^{\mathrm{H}}<0$ and $\mathrm{R}_{\mathrm{LL}}^{\mathrm{L}}<0$ from (15), it remains to show that $\mathrm{Z}>0$. For this, we use $\mathrm{R}_{\mathrm{H}}^{\mathrm{H}}=4\left(\phi(\mathrm{r})+\mathrm{r} \phi^{\prime}(\mathrm{r})\right)$ $\left.=4 \mathrm{R}_{\mathrm{L}}^{\mathrm{L}}+8 \mathrm{r} \phi^{\prime}(\mathrm{r})\right)$ from (14) and $\mathrm{R}_{\mathrm{L}}^{\mathrm{H}}=-4(\mathrm{r})^{2} \phi^{\prime}(\mathrm{r})$ from (11) to obtain $\mathrm{R}_{\mathrm{L}}^{\mathrm{H}}=2 \mathrm{rR}_{\mathrm{L}}^{\mathrm{L}}-\mathrm{rR}_{\mathrm{H}}^{\mathrm{H}} / 2$. Using the first order conditions (13), this implies $\mathrm{R}_{\mathrm{L}}^{\mathrm{H}}=2 \mathrm{r} \lambda^{\mathrm{L}} \mathrm{F}^{\prime}\left(\mathrm{q}^{\mathrm{L}}\right)-\mathrm{r} \lambda^{\mathrm{H}} \mathrm{F}^{\prime}\left(\mathrm{q}^{\mathrm{H}}\right) / 2$ and hence

$$
\mathrm{Z}=\mathrm{r} \lambda^{\mathrm{H}} \mathrm{T}\left(\mathrm{q}^{\mathrm{H}}\right) / 2+2 \mathrm{r} \lambda^{\mathrm{L}} \mathrm{F}^{\prime}\left(\mathrm{q}^{\mathrm{L}}\right) \mathrm{F}^{\prime}\left(\mathrm{q}^{\mathrm{H}}\right) \text { for } \mathrm{T}(\mathrm{q}) \equiv 2 \mathrm{~F}^{\prime \prime}(\mathrm{q}) \mathrm{F}(\mathrm{q})-\left(\mathrm{F}^{\prime}(\mathrm{q})\right)^{2} .
$$

Using $\mathrm{F}^{\prime \prime \prime}(\mathrm{q}) \geq 0$, we obtain $\mathrm{T}^{\prime}(\mathrm{q})=2 \mathrm{~F}(\mathrm{q}) \mathrm{F}^{\prime \prime \prime}(\mathrm{q}) \geq 0$ and since $\mathrm{T}(0)=0$, we have $\mathrm{T}(\mathrm{q}) \geq 0$ and $\mathrm{Z}>0$.

Proposition 1. Assume Bertrand price competition. Under conditions (1), if $\gamma \geq 1$ is sufficiently large, there exists a unique pure strategy equilibrium in which the low quality product is produced in the LDC and the high quality product is produced in the developed country.

Proof. Suppose firm i for $\mathrm{i}=1,2$ faces an investment cost $\gamma^{\mathrm{i}}$. For any quality $\mathrm{q}^{\mathrm{j}}$ set by firm $\mathrm{j}$, the profits of firm $i$ for $\mathrm{i} \neq \mathrm{j}$ and $\mathrm{i}, \mathrm{j}=1,2$ are given by $\pi^{\mathrm{iL}}$ if it is the low quality producer and $\pi^{\mathrm{iH}}$ if it is the high quality producer. Since $\lambda^{\mathrm{L}}=\gamma^{\mathrm{i}}$ if $\mathrm{q}^{\mathrm{i}}=\mathrm{q}^{\mathrm{iL}}$ and $\lambda^{\mathrm{H}}=\gamma^{\mathrm{i}}$ if $\mathrm{q}^{\mathrm{i}}=\mathrm{q}^{\mathrm{iH}}$, from (12), we obtain: 


$$
\begin{aligned}
& \pi^{i L}=\pi^{L}\left(q^{i L}, q^{j} ; \gamma^{i}\right)=R^{i L}-\gamma^{i} F\left(q^{i L}\right) \text { for } R^{i L}=\phi\left(r^{i L}\right) q^{i L} \text { and } r^{i L} \equiv q^{j} / q^{i L} \\
& \pi^{i H}=\pi^{H}\left(q^{j}, q^{i H} ; \gamma^{i}\right)=R^{i H}-\gamma^{i} F\left(q^{i H}\right) \text { for } R^{i H}=4 \phi\left(r^{i H}\right) q^{i H} \text { and } r^{i H} \equiv q^{i H} / q^{j}
\end{aligned}
$$

We assume that $\mathrm{q}^{\mathrm{iL}}<\mathrm{q}^{\mathrm{j}}$ and $\mathrm{q}^{\mathrm{iH}}>\mathrm{q}^{\mathrm{j}}$ are at their profit maximizing levels for any given value of $\mathrm{q}^{\mathrm{j}}$ and hence satisfy the reaction functions, $q^{i L}=\rho^{\mathrm{L}}\left(q^{\mathrm{j}}, \gamma^{\mathrm{i}}\right)$ and $\mathrm{q}^{\mathrm{iH}}=\rho^{\mathrm{H}}\left(\mathrm{q}^{\mathrm{j}}, \gamma^{\mathrm{i}}\right)$, defined respectively by

$$
\pi_{\mathrm{L}}^{\mathrm{iL}}=\mathrm{R}_{\mathrm{L}}^{\mathrm{iL}}-\gamma^{\mathrm{i}} \mathrm{F}^{\prime}\left(\mathrm{q}^{\mathrm{iL}}\right)=0 \text { and } \pi_{\mathrm{H}}^{\mathrm{iH}}=\mathrm{R}_{\mathrm{H}}^{\mathrm{iH}}-\gamma^{\mathrm{i}} \mathrm{F}^{\prime}\left(\mathrm{q}^{\mathrm{iH}}\right)=0,
$$

where $\mathrm{R}_{\mathrm{L}}^{\mathrm{iL}}=\phi\left(\mathrm{r}^{\mathrm{iL}}\right)-\mathrm{r}^{\mathrm{iL}} \phi^{\prime}\left(\mathrm{r}^{\mathrm{iL}}\right)$ and $\mathrm{R}_{\mathrm{H}}^{\mathrm{iH}}=4\left[\phi\left(\mathrm{r}^{\mathrm{iH}}\right)+\mathrm{r}^{\mathrm{iH}} \phi^{\prime}\left(\mathrm{r}^{\mathrm{iH}}\right)\right]$. Since (15) and (16) are satisfied, there are only two potential Nash equilibria, $\left(\mathrm{q}^{1 \mathrm{~L}}, \mathrm{q}^{2 \mathrm{H}}\right)$, and the "switched" allocation $\left(\mathrm{q}^{2 \mathrm{~L}}, \mathrm{q}^{1 \mathrm{H}}\right)$.

We first show that both firms earn strictly positive profits at $\left(\mathrm{q}^{1 \mathrm{~L}}, \mathrm{q}^{2 \mathrm{H}}\right)$. From (A.3), using $\mathrm{F}(\mathrm{q})<$ $F^{\prime}(q) q\left(\right.$ from $F(0)=0, F^{\prime}(q)>0$ and $F^{\prime \prime}(q)>0$ ) and (A.4), it follows that, for any $q^{j}$ and $\gamma^{i}$, if firm i is firm L, producing $q^{i L}=\rho^{L}\left(q^{j}, \gamma^{i}\right)$, then $\pi^{i L}=\phi\left(r^{i L}\right) q^{i L}-\gamma^{i} F\left(q^{i L}\right)>\left(\phi\left(r^{i L}\right)-\gamma^{i} F^{\prime}\left(q^{i L}\right)\right) q^{i L}=r^{i L} \phi^{\prime}\left(r^{i L}\right) q^{i L}>0$. If firm $\mathrm{i}$ is firm $\mathrm{H}$, from (A.3), using $\phi(r)=r(r-1) /(4 r-1)^{2}$, we obtain $\mathrm{R}^{\mathrm{iH}}-\mathrm{R}^{\mathrm{jL}}=\mathrm{q}^{\mathrm{iH}}(\mathrm{r}-1) /(4 \mathrm{r}-1)$ for $\mathrm{r}=\mathrm{q}^{\mathrm{iH}} / \mathrm{q}^{\mathrm{jL}}$. Since $\gamma^{\mathrm{i}}\left(\mathrm{F}\left(\mathrm{q}^{\mathrm{iH}}\right)-\mathrm{F}\left(\mathrm{q}^{\mathrm{jL}}\right)\right)<\gamma^{\mathrm{i}} \mathrm{F}^{\prime}\left(\mathrm{q}^{\mathrm{iH}}\right)\left(\mathrm{q}^{\mathrm{iH}}-\mathrm{q}^{\mathrm{iL}}\right)=\mathrm{R}_{\mathrm{H}}^{\mathrm{iH}} \mathrm{q}^{\mathrm{iH}}(\mathrm{r}-1) / \mathrm{r}$ from $\mathrm{F}^{\prime \prime}(\mathrm{q})>0$ and $(\mathrm{A} .4)$ and since $\left[\mathrm{r} /(4 \mathrm{r}-1)-\mathrm{R}_{\mathrm{H}}^{\mathrm{iH}}\right] / \mathrm{r}$ $=(4 r-7) /(4 r-1)^{3}>0$ from $r>7 / 4$ for $\mathrm{R}_{\mathrm{L}}^{\mathrm{iL}}>0$, it follows that

$$
\pi^{\mathrm{iH}}-\pi^{\mathrm{jL}}>\mathrm{q}^{\mathrm{iH}}(\mathrm{r}-1)\left[\mathrm{r} /(4 \mathrm{r}-1)-\mathrm{R}_{\mathrm{H}}^{\mathrm{iH}}\right] / \mathrm{r}+\left(\gamma^{\mathrm{j}}-\gamma^{\mathrm{i}}\right) \mathrm{F}\left(\mathrm{q}^{\mathrm{iL}}\right)>0 \text { for } \gamma^{\mathrm{j}}-\gamma^{\mathrm{i}} \geq 0 .
$$

For $\left(\mathrm{q}^{1 \mathrm{~L}}, \mathrm{q}^{2 \mathrm{H}}\right)$ to be globally stable, we also require that firm 1 , taking $\mathrm{q}^{2}=\mathrm{q}^{2 \mathrm{H}}=\rho^{\mathrm{H}}\left(\mathrm{q}^{1 \mathrm{~L}}, \gamma^{2}\right)$ as given, would set $q^{1 \mathrm{~L}}=\rho^{\mathrm{L}}\left(\mathrm{q}^{2 \mathrm{H}}, \gamma^{1}\right)=q^{\mathrm{L}}\left(\gamma^{1}, \gamma^{2}\right)$, rather than attempting to become firm H by setting $\mathrm{q}^{1}=\rho^{\mathrm{H}}\left(\mathrm{q}^{2 \mathrm{H}}, \gamma^{2}\right)$ $>q^{2 \mathrm{H}}$. Similarly, we require that firm 2, taking $\mathrm{q}^{1}=\mathrm{q}^{1 \mathrm{~L}}=\rho^{\mathrm{L}}\left(\mathrm{q}^{2 \mathrm{H}}, \gamma^{1}\right)$ as given, would prefer $\mathrm{q}^{2 \mathrm{H}}=\rho^{\mathrm{H}}\left(\mathrm{q}^{1 \mathrm{~L}}, \gamma^{2}\right)$ $=\mathrm{q}^{\mathrm{H}}\left(\gamma^{1}, \gamma^{2}\right)$ rather than $\mathrm{q}^{2}=\rho^{\mathrm{L}}\left(\mathrm{q}^{1 \mathrm{~L}}, \gamma^{2}\right)<\mathrm{q}^{1 \mathrm{~L}}$. Thus, letting $\Delta^{\mathrm{i}}=\Delta\left(\mathrm{q}^{\mathrm{j}}, \gamma^{\mathrm{i}}\right) \equiv \pi^{\mathrm{iL}}\left(\rho^{\mathrm{L}}\left(\mathrm{q}^{\mathrm{j}}, \gamma^{\mathrm{i}}\right), \mathrm{q}^{\mathrm{j}}, \gamma^{\mathrm{i}}\right)-\pi^{\mathrm{iH}}\left(\mathrm{q}^{\mathrm{j}}\right.$, $\left.\rho^{\mathrm{H}}\left(\mathrm{q}^{\mathrm{j}}, \gamma^{\mathrm{i}}\right), \gamma^{\mathrm{i}}\right)$ represent the difference in profit earned by firm i from production of $\mathrm{q}^{\mathrm{iL}}$ rather than $\mathrm{q}^{\mathrm{iH}}$ for any given quality $\mathrm{q}^{\mathrm{j}}$ set by the other firm, we require $\Delta^{1}=\Delta\left(\mathrm{q}^{2 \mathrm{H}}, \gamma^{1}\right)>0$ for $\mathrm{q}^{2 \mathrm{H}}=\rho^{\mathrm{H}}\left(\mathrm{q}^{1 \mathrm{~L}}, \gamma^{2}\right)$ and $\Delta^{2}=\Delta\left(\mathrm{q}^{1 \mathrm{~L}}, \gamma^{2}\right)$ $<0$ for $\mathrm{q}^{1 \mathrm{~L}}=\rho^{\mathrm{L}}\left(\mathrm{q}^{2 \mathrm{H}}, \gamma^{1}\right)$. Conversely, the switched allocation $\left(\mathrm{q}^{2 \mathrm{~L}}, \mathrm{q}^{1 \mathrm{H}}\right)$ is not globally stable if $\Delta^{1}=\Delta\left(\mathrm{q}^{2 \mathrm{~L}}, \gamma^{1}\right)$ $<0$ for $\mathrm{q}^{2 \mathrm{~L}}=\rho^{\mathrm{L}}\left(\mathrm{q}^{1 \mathrm{H}}, \gamma^{2}\right)$ or if $\Delta^{2}=\Delta\left(\mathrm{q}^{1 \mathrm{H}}, \gamma^{2}\right)>0$ for $\mathrm{q}^{1 \mathrm{H}}=\rho^{\mathrm{H}}\left(\mathrm{q}^{2 \mathrm{~L}}, \gamma^{1}\right)$.

To obtain these results, we first use (A.3) to express $\Delta^{\mathrm{i}}$ in the form:

$$
\Delta^{\mathrm{i}}=\Delta\left(\mathrm{q}^{\mathrm{j}}, \gamma^{\mathrm{i}}\right)=\phi\left(\mathrm{r}^{\mathrm{iL}}\right) \mathrm{q}^{\mathrm{iL}}-4 \phi\left(\mathrm{r}^{\mathrm{iH}}\right) \mathrm{q}^{\mathrm{iH}}+\gamma^{\mathrm{i}}\left[\mathrm{F}\left(\mathrm{q}^{\mathrm{iH}}\right)-\mathrm{F}\left(\mathrm{q}^{\mathrm{iL}}\right)\right]
$$

From (A.4), allowing $r^{i L} \equiv q^{j} / q^{i L}$ for $q^{i L}=\rho^{L}\left(q^{j}, \gamma^{i}\right)$ and $r^{i H} \equiv q^{i H} / q^{j}$ for $q^{i H}=\rho^{H}\left(q^{j}, \gamma^{i}\right)$ to vary, we then obtain:

$$
\partial \Delta^{\mathrm{i}} / \partial \gamma^{\mathrm{i}}=\mathrm{F}\left(\mathrm{q}^{\mathrm{iH}}\right)-\mathrm{F}\left(\mathrm{q}^{\mathrm{iL}}\right)>0 \text { for any } \mathrm{q}^{\mathrm{j}} \text { and } \partial \Delta^{\mathrm{i}} / \partial \mathrm{q}^{\mathrm{j}}=\phi^{\prime}\left(\mathrm{r}^{\mathrm{iL}}\right)+4\left(\mathrm{r}^{\mathrm{iH}}\right)^{2} \phi^{\prime}\left(\mathrm{r}^{\mathrm{iH}}\right)>0
$$


With respect to firm 1, from (A.3) and (A.4), we obtain:

$$
\pi^{1 \mathrm{H}}=-4 \mathrm{r}^{1 \mathrm{H}} \phi^{\prime}\left(\mathrm{r}^{1 \mathrm{H}}\right) \mathrm{q}^{1 \mathrm{H}}+\gamma^{1}\left[\mathrm{q}^{1 \mathrm{H}} \mathrm{F}^{\prime}\left(\mathrm{q}^{1 \mathrm{H}}\right)-\mathrm{F}\left(\mathrm{q}^{1 \mathrm{H}}\right)\right] .
$$

Since $\mathrm{q}^{1 \mathrm{H}} \mathrm{F}^{\prime}\left(\mathrm{q}^{1 \mathrm{H}}\right)-\mathrm{F}\left(\mathrm{q}^{1 \mathrm{H}}\right)>0$ from $(1)$, this implies $\pi^{1 \mathrm{H}}=0$ for $\gamma^{1}=\gamma^{1 \mathrm{H}}\left(\mathrm{q}^{2}\right)=4 \mathrm{r}^{1 \mathrm{H}} \phi^{\prime}\left(\mathrm{r}^{1 \mathrm{H}}\right) \mathrm{q}^{1 \mathrm{H}} /\left[\mathrm{q}^{1 \mathrm{H}} \mathrm{F}^{\prime}\left(\mathrm{q}^{1 \mathrm{H}}\right)\right.$ $\left.\mathrm{F}\left(\mathrm{q}^{1 \mathrm{H}}\right)\right]>0$. Then, since $\mathrm{d} \pi^{1 \mathrm{H}} / \mathrm{d} \gamma^{1}<0$ from Lemma 1 , setting $\mathrm{q}^{2}=\mathrm{q}^{2 \mathrm{~L}}=\mathrm{q}^{\mathrm{L}}\left(\gamma^{2}, \gamma^{1}\right)$, it follows that $\pi^{1 \mathrm{H}}<0$ and hence (using $\pi^{\mathrm{iL}}>0$ ) that $\Delta^{1}\left(\mathrm{q}^{2 \mathrm{~L}}, \gamma^{1}\right)>0$ for $\gamma^{1}>\gamma^{1 \mathrm{H}}\left(\mathrm{q}^{2 \mathrm{~L}}\right)$. Thus firm 1 will set $\mathrm{q}^{1}<\mathrm{q}^{2 \mathrm{~L}}$, breaking the switched equilibrium $\left(\mathrm{q}^{2 \mathrm{~L}}, \mathrm{q}^{1 \mathrm{H}}\right)$ for $\gamma^{1}>\gamma^{1 \mathrm{H}}\left(\mathrm{q}^{2 \mathrm{~L}}\right)$. Alternatively, if $\mathrm{q}^{2}=\mathrm{q}^{2 \mathrm{H}}=\mathrm{q}^{\mathrm{H}}\left(\gamma^{1}, \gamma^{2}\right)$, then since $\mathrm{q}^{2 \mathrm{H}}>\mathrm{q}^{2 \mathrm{~L}}$ and $\mathrm{d} \Delta^{1} / \mathrm{dq} \mathrm{q}^{2}>0$ from (A.6), it follows that for $\gamma^{1}>\gamma^{1 \mathrm{H}}\left(\mathrm{q}^{2 \mathrm{~L}}\right)$, we have $\Delta^{1}\left(\mathrm{q}^{2 \mathrm{H}}, \gamma^{1}\right)>0$ and hence that $\left(\mathrm{q}^{1 \mathrm{~L}}, \mathrm{q}^{2 \mathrm{H}}\right)$ is globally stable for firm 1. For firm 2, if $\gamma^{1}=\gamma^{2}$, then we have $\Delta^{2}=\Delta\left(\mathrm{q}^{1 \mathrm{~L}}, \gamma^{2}\right)<0$, since $\pi^{2 \mathrm{~L}}\left(\rho^{\mathrm{L}}\left(\mathrm{q}^{1 \mathrm{~L}}, \gamma^{2}\right), \mathrm{q}^{1 \mathrm{~L}}, \gamma^{2}\right)<\pi^{2 \mathrm{~L}}\left(\rho^{\mathrm{L}}\left(\mathrm{q}^{1 \mathrm{H}}, \gamma^{2}\right), \mathrm{q}^{1 \mathrm{H}}, \gamma^{2}\right)<\pi^{2 \mathrm{H}}\left(\mathrm{q}^{1 \mathrm{~L}}, \rho^{\mathrm{H}}\left(\mathrm{q}^{2 \mathrm{~L}}, \gamma^{2}\right), \gamma^{2}\right)$ where the first inequality follows from $\mathrm{d} \pi^{2 \mathrm{~L}} / \mathrm{dq}^{1}>0$ and the second from (A.5). Since $\mathrm{dq} / \mathrm{d} \gamma^{1}<0$ and $\mathrm{d} \Delta^{2} / \mathrm{d} \gamma^{1}=\left(\mathrm{d} \Delta^{2} / \mathrm{dq}^{1 \mathrm{~L}}\right)\left(\mathrm{dq} \mathrm{q}^{1 \mathrm{~L}} / \mathrm{d} \gamma^{1}\right)<0$, it then follows that $\Delta^{2}=\Delta\left(\mathrm{q}^{\mathrm{iL}}, \gamma^{2}\right)<0$ for all $\gamma^{1} \geq \gamma^{2}$ and hence that $\left(\mathrm{q}^{1 \mathrm{~L}}, \mathrm{q}^{2 \mathrm{H}}\right)$ is stable for firm 2 .

Proposition 4. Assume Bertrand competition. (i) The subsidy, $s^{L *}$, maximizes the LDC's rents from exports by shifting the equilibrium to what would have been the Stackelberg leader-follower point in quality space with the low quality firm as the leader and no subsidy. For $\gamma$ sufficiently large, the LDCfirm does not choose to become the high quality producer. (ii) Under conditions (1), profit $\pi^{L}\left(q^{L}, \rho^{H}\left(q^{L}\right), \lambda^{L}\right)$ of the leader firm is (strictly) globally concave in $q^{L}$ and LDC welfare, $W^{L}$, is locally concave at $s^{L}=s^{L *}$.

Proof. (i) Since $d W^{L} / d s^{L}=\left(d \pi^{L}\left(q^{L}, \rho^{H}\left(q^{L}\right), \gamma\right) / d q^{L}\right)\left(d q^{L} / d s^{L}\right)$ from (21), it follows that at $s^{L}=s^{L} * q^{L}$ satisfies $\mathrm{d} \pi^{\mathrm{L}}\left(\mathrm{q}^{\mathrm{L}}, \rho^{\mathrm{H}}\left(\mathrm{q}^{\mathrm{L}}\right), \gamma\right) / \mathrm{dq}^{\mathrm{L}}=\mathrm{R}_{\mathrm{L}}^{\mathrm{L}}+\mathrm{R}_{\mathrm{H}}^{\mathrm{L}}\left(\mathrm{dq}^{\mathrm{H}} / \mathrm{dq}^{\mathrm{L}}\right)-\gamma \mathrm{F}^{\prime}\left(\mathrm{q}^{\mathrm{L}}\right)=0$, which is the value of $\mathrm{q}^{\mathrm{L}}$ that would be chosen by firm $L$ as a Stackelberg leader at $\mathrm{s}^{\mathrm{L}}=0$. Since $\pi^{\mathrm{L}}>0$ at the Nash equilibrium (from Proposition 1), we have $\pi^{\mathrm{L}}\left(\mathrm{q}^{\mathrm{L}}, \rho^{\mathrm{H}}\left(\mathrm{q}^{\mathrm{L}}\right), \gamma\right)>0$. To show that the leader firm would not set $\mathrm{q}^{1}=\mathrm{q}^{1 \mathrm{H}}$, letting $\alpha \equiv \mathrm{q}^{\mathrm{H}}\left(\mathrm{dr} / \mathrm{dq} \mathrm{q}^{\mathrm{H}}\right) / \mathrm{r}$ represent the elasticity of $r$ with respect to $q^{H}$, from $d r / d q^{H}=\left(1-r\left(d q^{L} / d q^{H}\right)\right) / q^{L}$ and $d q^{L} / d q^{H}=R^{L}{ }_{L L} / r \pi^{L}{ }_{L L}$, we obtain

$$
\alpha=-\lambda^{\mathrm{L}} \mathrm{F}^{\prime \prime}\left(\mathrm{q}^{\mathrm{L}}\right) / \pi_{\mathrm{LL}}^{\mathrm{L}}>0, \mathrm{dr} / \mathrm{dq}^{\mathrm{H}}=\alpha / \mathrm{q}^{\mathrm{L}}>0 \text { and } 1-\alpha=\mathrm{R}_{\mathrm{LL}}^{\mathrm{L}} / \pi^{\mathrm{L}}{ }_{\mathrm{LL}}>0 .
$$

It then follows from (A.3) that $\mathrm{d} \pi^{1 \mathrm{H}} / \mathrm{dq}^{\mathrm{H}}=4\left(\phi(\mathrm{r})+\alpha \mathrm{r} \phi^{\prime}(\mathrm{r})\right)-\lambda^{\mathrm{H}} \mathrm{F}^{\prime}\left(\mathrm{q}^{\mathrm{H}}\right)=0$ and since $\mathrm{qF}^{\prime}(\mathrm{q})-\mathrm{F}(\mathrm{q})>0$ from (1) and $\mathrm{d} \pi^{1 \mathrm{H}} / \mathrm{d} \gamma=-\mathrm{F}\left(\mathrm{q}^{1 \mathrm{H}}\right)<0$, it can be shown that $\pi^{1 \mathrm{H}}=-4 \alpha \mathrm{r}^{1 \mathrm{H}} \phi^{\prime}\left(\mathrm{r}^{1 \mathrm{H}}\right) \mathrm{q}^{1 \mathrm{H}}+\gamma\left[\mathrm{q}^{1 \mathrm{H}} \mathrm{F}^{\prime}\left(\mathrm{q}^{1 \mathrm{H}}\right)-\mathrm{F}\left(\mathrm{q}^{1 \mathrm{H}}\right)\right]<0$ for $\mathrm{r}^{1 \mathrm{H}}=\mathrm{q}^{1 \mathrm{H}} / \rho^{\mathrm{L}}\left(\mathrm{q}^{1 \mathrm{H}}\right)$ and $\gamma$ sufficiently large. (ii) From (21), we have $d W^{\mathrm{L}} / \mathrm{ds}^{\mathrm{L}}=\left(\mathrm{d} \pi^{\mathrm{L}} / \mathrm{dq}^{\mathrm{L}}\right)\left(\mathrm{dq}^{\mathrm{L}} / \mathrm{ds}^{\mathrm{L}}\right)$ for $\pi^{\mathrm{L}}=$ $\pi^{\mathrm{L}}\left(\mathrm{q}^{\mathrm{L}}, \rho^{\mathrm{H}}\left(\mathrm{q}^{\mathrm{L}}\right), \gamma\right)$ and hence $\mathrm{d}^{2} \mathrm{~W}^{\mathrm{L}} /\left(\mathrm{ds}^{\mathrm{L}}\right)^{2}=\left(\mathrm{d}^{2} \pi^{\mathrm{L}} /\left(\mathrm{dq}^{\mathrm{L}}\right)^{2}\right)\left(\mathrm{dq}^{\mathrm{L}} / \mathrm{ds}^{\mathrm{L}}\right)^{2}+\left(\mathrm{d} \pi^{\mathrm{L}} / \mathrm{dq}^{\mathrm{L}}\right)\left(\mathrm{d}^{2} \mathrm{q}^{\mathrm{L}} /\left(\mathrm{ds}^{\mathrm{L}}\right)^{2}\right)$. Since $\mathrm{dW} / \mathrm{ds}^{\mathrm{L}}=$ 
$\mathrm{d} \pi^{\mathrm{L}} / \mathrm{dq}^{\mathrm{L}}=0$ at $\mathrm{s}^{\mathrm{L} *}$, it follows that $\mathrm{d}^{2} \pi^{\mathrm{L}} /\left(\mathrm{dq}^{\mathrm{L}}\right)^{2}<0$ implies $\mathrm{d}^{2} \mathrm{~W}^{\mathrm{L}} /\left(\mathrm{ds}^{\mathrm{L}}\right)^{2}<0$ at $\mathrm{s}^{\mathrm{L} *}$.

To show $d^{2} \pi^{L} /\left(d q^{L}\right)^{2}<0$ for $q^{H}=\rho^{H}\left(q^{L}\right)$ and general investment cost, $\lambda^{L} F\left(q^{L}\right)$, letting $\beta \equiv-$ $\mathrm{q}^{\mathrm{L}}\left(\mathrm{dr} / \mathrm{dq}^{\mathrm{L}}\right) / \mathrm{r}$, it follows, using $\mathrm{dr} / \mathrm{dq}^{\mathrm{L}}=-\left(\mathrm{r}-\mathrm{dq}^{\mathrm{H}} / \mathrm{dq}^{\mathrm{L}}\right) / \mathrm{q}^{\mathrm{L}}, \mathrm{dq}^{\mathrm{H}} / \mathrm{dq}^{\mathrm{L}}=\mathrm{rR}_{\mathrm{HH}_{\mathrm{H}}}^{\mathrm{H}} / \pi^{\mathrm{H}}{ }_{\mathrm{HH}}$ and $\pi_{\mathrm{HH}}^{\mathrm{H}}=\mathrm{R}_{\mathrm{HH}}^{\mathrm{H}}-\lambda^{\mathrm{H}} \mathrm{F}^{\prime \prime}\left(\mathrm{q}^{\mathrm{H}}\right)$ from (17) and (15), that $\beta=-\lambda^{\mathrm{H}} \mathrm{F}^{\prime \prime}\left(\mathrm{q}^{\mathrm{H}}\right) / \pi_{\mathrm{HH}}^{\mathrm{H}}>0$ and that

$$
\mathrm{dr} / \mathrm{dq}^{\mathrm{L}}=-\mathrm{r} \beta / \mathrm{q}^{\mathrm{L}}<0, \mathrm{dq}^{\mathrm{H}} / \mathrm{dq}^{\mathrm{L}}=\mathrm{r}(1-\beta) \text { and } 1-\beta=\mathrm{R}_{\mathrm{HH}}^{\mathrm{H}} / \pi_{\mathrm{HH}}^{\mathrm{H}}>0 .
$$

From $\pi^{\mathrm{L}}=\phi(\mathrm{r}) \mathrm{q}^{\mathrm{L}}-\lambda^{\mathrm{L}} \mathrm{F}\left(\mathrm{q}^{\mathrm{L}}\right)$ and (A.9), we then obtain $\mathrm{d} \pi^{\mathrm{L}} / \mathrm{dq} \mathrm{q}^{\mathrm{L}}=\phi(\mathrm{r})-\mathrm{r} \beta \phi^{\prime}(\mathrm{r})-\lambda^{\mathrm{L}} \mathrm{F}^{\prime}\left(\mathrm{q}^{\mathrm{L}}\right)$ and hence

$$
d^{2} \pi^{L} /\left(d q^{L}\right)^{2}=-\lambda^{L} F^{\prime \prime}\left(q^{L}\right)+r \beta\left[r \beta \phi^{\prime \prime}(r)-(1-\beta) \phi^{\prime}(r)\right] / q^{L}-r \phi^{\prime}(r)\left(d \beta / d q^{L}\right) \text {. }
$$

Using $\mathrm{dq}^{\mathrm{H}} / \mathrm{dq}^{\mathrm{L}}=\mathrm{r}(1-\beta)$, we have $\mathrm{d} \beta / \mathrm{dq}^{\mathrm{L}}=-\lambda^{\mathrm{H}}\left[\mathrm{F}^{\prime \prime \prime}\left(\mathrm{q}^{\mathrm{H}}\right) \mathrm{r}(1-\beta) / \pi_{\mathrm{HH}}^{\mathrm{H}}-\mathrm{F}^{\prime \prime}\left(\mathrm{q}^{\mathrm{H}}\right)\left(\mathrm{d} \pi^{\mathrm{H}}{ }_{\mathrm{HH}} / \mathrm{dq}^{\mathrm{L}}\right) /\left(\pi_{\mathrm{HH}}^{\mathrm{H}}\right)^{2}\right]$. Since $\mathrm{d} \pi^{\mathrm{H}}{ }_{\mathrm{HH}} / \mathrm{dq}^{\mathrm{L}}=\mathrm{dR}^{\mathrm{H}}{ }_{\mathrm{HH}} / \mathrm{dq}^{\mathrm{L}}-\lambda^{\mathrm{H}} \mathrm{F}^{\prime \prime \prime}\left(\mathrm{q}^{\mathrm{H}}\right) \mathrm{r}(1-\beta)$, letting $\xi \equiv-\lambda^{\mathrm{H}} \mathrm{F}^{\prime \prime \prime}\left(\mathrm{q}^{\mathrm{H}}\right) / \pi^{\mathrm{H}}{ }_{\mathrm{HH}} \geq 0$ from $\mathrm{F}^{\prime \prime \prime}(\mathrm{q}) \geq 0$, this implies

$$
\mathrm{d} \beta / \mathrm{dq}^{\mathrm{L}}=\mathrm{r}(1-\beta)^{2} \xi-\beta\left(\mathrm{dR}_{\mathrm{HH}}^{\mathrm{H}} / \mathrm{dq}^{\mathrm{L}}\right) / \pi_{\mathrm{HH}}^{\mathrm{H}} \cdot
$$

Letting $\Upsilon \equiv \mathrm{R}^{\mathrm{H}}{ }_{\mathrm{HH}}\left[\phi^{\prime}(\mathrm{r})-\mathrm{r} \beta \phi^{\prime \prime}(\mathrm{r})\right] / \mathrm{q}^{\mathrm{L}} \pi_{\mathrm{HH}}^{\mathrm{H}}-\phi^{\prime}(\mathrm{r})\left(\mathrm{dR}^{\mathrm{H}}{ }_{\mathrm{HH}} / \mathrm{dq}^{\mathrm{L}}\right) / \pi^{\mathrm{H}}{ }_{\mathrm{HH}}$, it then follows from (A.10), using $\mathrm{r} \beta \phi^{\prime \prime}(\mathrm{r})-(1-\beta) \phi^{\prime}(\mathrm{r})=(1-\beta)\left(\mathrm{r} \beta \phi^{\prime \prime}(\mathrm{r})-\phi^{\prime}(\mathrm{r})\right)+\mathrm{r}(\beta)^{2} \phi^{\prime \prime}(\mathrm{r}), 1-\beta=\mathrm{R}_{\mathrm{HH}}^{\mathrm{H}} / \pi_{\mathrm{HH}}^{\mathrm{H}}$ and (A.11), that

$$
\left.d^{2} \pi^{\mathrm{L}} /(\mathrm{dq})^{\mathrm{L}}\right)^{2}=-\lambda^{\mathrm{L}} \mathrm{F}^{\prime \prime}\left(\mathrm{q}^{\mathrm{L}}\right)+(\mathrm{r})^{2}(\beta)^{3} \phi^{\prime \prime}(\mathrm{r}) / \mathrm{q}^{\mathrm{L}}-(\mathrm{r})^{2}(1-\beta)^{2} \phi^{\prime}(\mathrm{r}) \xi-\mathrm{r} \beta \Upsilon .
$$

Since $\phi^{\prime}(\mathrm{r})>0, \phi^{\prime \prime}(\mathrm{r})<0, \beta>0$ and $\xi \geq 0$, it remains to show that $\Upsilon \geq 0$. From $\mathrm{R}_{\mathrm{HH}}^{\mathrm{H}}=-8(5 \mathrm{r}+1) /(4 \mathrm{r}-1)^{4} \mathrm{q}^{\mathrm{L}}$ and (A.9), we obtain $\mathrm{dR}^{\mathrm{H}}{ }_{\mathrm{HH}} / \mathrm{dq}^{\mathrm{L}}=\mathrm{R}_{\mathrm{HHL}}^{\mathrm{H}}+\mathrm{rR}_{\mathrm{HHH}}^{\mathrm{H}}(1-\beta)$ where $\mathrm{R}_{\mathrm{HHL}}^{\mathrm{H}}=-\mathrm{R}_{\mathrm{HH}}^{\mathrm{H}} / \mathrm{q}^{\mathrm{L}}-\mathrm{rR}_{\mathrm{HHH}}^{\mathrm{H}}$ and hence

$$
\mathrm{dR}_{\mathrm{HH}}^{\mathrm{H}} / \mathrm{dq}^{\mathrm{L}}=-\mathrm{R}_{\mathrm{HH}}^{\mathrm{H}} / \mathrm{q}^{\mathrm{L}}-\mathrm{r} \beta \mathrm{R}_{\mathrm{HHH}}^{\mathrm{H}} \text { for } \mathrm{R}_{\mathrm{HHH}}^{\mathrm{H}}=24(20 \mathrm{r}+7) /(4 \mathrm{r}-1)^{5}\left(\mathrm{q}^{\mathrm{L}}\right)^{2}>0 \text {. }
$$

Using (A.12), this implies $\Upsilon=\left[2 q^{\mathrm{L}} \mathrm{R}^{\mathrm{H}}{ }_{\mathrm{HH}} \phi^{\prime}(\mathrm{r})+\mathrm{r} \beta \tau\right] / \pi_{H \mathrm{H}}^{\mathrm{H}}\left(\mathrm{q}^{\mathrm{L}}\right)^{2}$ for $\tau \equiv-\left[\mathrm{q}^{\mathrm{L}} \mathrm{R}_{\mathrm{HH}}^{\mathrm{H}} \phi^{\prime \prime}(\mathrm{r})-\phi^{\prime}(\mathrm{r})\left(\mathrm{q}^{\mathrm{L}}\right)^{2} \mathrm{R}^{\mathrm{H}}{ }_{\mathrm{HHH}}\right]$. Using $\phi^{\prime}(r)=(2 r+1) /(4 r-1)^{3}$ and $\phi^{\prime \prime}(r)=-2(8 r+7) /(4 r-1)^{4}$, we have $r \tau=8\left(40(r)^{3}+16(r)^{2}+7 r\right) /(4 r-1)^{8}>0$ and $2 q^{\mathrm{L}} \mathrm{R}_{\text {HH }}^{\mathrm{H}} \phi^{\prime}(\mathrm{r})=-16\left[40(\mathrm{r})^{3}+18(\mathrm{r})^{2}-3 \mathrm{r}-1\right] /(4 \mathrm{r}-1)^{8}$. Hence, it follows using $1-\beta>0$ and $\mathrm{r} \geq 1$ that:

$$
\Upsilon=-\left[\mathrm{r} \tau(1-\beta)+8\left(40(\mathrm{r})^{3}+20(\mathrm{r})^{2}-13 \mathrm{r}-2\right)\right] /(4 \mathrm{r}-1)^{8}\left(\mathrm{q}^{\mathrm{L}}\right)^{2} \pi_{\text {HH }}^{\mathrm{H}}>0 .
$$

Lemma 2: Assume Bertrand competition and conditions (1). If $E=q F^{\prime \prime}(q) / F^{\prime}(q)$ is constant (which applies for $\left.F(q)=a(q)^{n}\right)$ this ensures local concavity of firm H's profit as a Stackelberg leader in quality space or equivalently, local concavity of welfare, $W^{H}$ with respect to $s^{H}$.

Proof: Recalling $\lambda^{\mathrm{H}}=1$ at $\mathrm{s}^{\mathrm{H}}=0$, it follows (analogous to $(21)$ ) that $\mathrm{W}^{\mathrm{H}}=\pi^{\mathrm{H}}\left(\mathrm{q}^{\mathrm{L}}, \mathrm{q}^{\mathrm{H}}, 1\right)$ where $\pi^{\mathrm{H}}\left(\mathrm{q}^{\mathrm{L}}, \mathrm{q}^{\mathrm{H}}, 1\right)=$ $R^{\mathrm{H}}\left(q^{\mathrm{L}}, \mathrm{q}^{\mathrm{H}}\right)-\mathrm{F}\left(\mathrm{q}^{\mathrm{H}}\right)$ and hence $\left.\mathrm{d}^{2} \mathrm{~W}^{\mathrm{H}} /\left(\mathrm{ds}^{\mathrm{H}}\right)^{2}=\left(\mathrm{d}^{2} \pi^{\mathrm{H}} /\left(\mathrm{dq}^{\mathrm{H}}\right)^{2}\right)\left(\mathrm{dq} \mathrm{q}^{\mathrm{H}} / \mathrm{ds}{ }^{\mathrm{H}}\right)^{2}+\left(\mathrm{d} \pi^{\mathrm{H}} / \mathrm{dq}^{\mathrm{H}}\right)\left(\mathrm{d}^{2} \mathrm{q}^{\mathrm{H}} /(\mathrm{ds})^{\mathrm{H}}\right)^{2}\right)$ for $\mathrm{q}^{\mathrm{L}}=\rho^{\mathrm{L}}\left(\mathrm{q}^{\mathrm{H}}\right)$. Since $\mathrm{dW}^{\mathrm{H}} / \mathrm{ds}^{\mathrm{H}}=\mathrm{d} \pi^{\mathrm{H}} / \mathrm{dq}^{\mathrm{H}}=0$ at $\mathrm{s}^{\mathrm{H} *}$, it follows that $\mathrm{d}^{2} \pi^{\mathrm{H}} /\left(\mathrm{dq}^{\mathrm{H}}\right)^{2}<0$ implies $\mathrm{d}^{2} \mathrm{~W}^{\mathrm{H}} /\left(\mathrm{ds}^{\mathrm{H}}\right)^{2}<0$ at $\mathrm{s}^{\mathrm{H} *}$. 
To show $\mathrm{d}^{2} \pi^{\mathrm{H}} /\left(\mathrm{dq}^{\mathrm{H}}\right)^{2}<0$, it follows from $\pi^{\mathrm{H}}=4 \phi(\mathrm{r}) \mathrm{q}^{\mathrm{H}}-\lambda^{\mathrm{H}} \mathrm{F}\left(\mathrm{q}^{\mathrm{H}}\right)$ and $\mathrm{dr} / \mathrm{dq}^{\mathrm{L}}=\alpha / \mathrm{q}^{\mathrm{L}}$ for $\alpha \equiv$ $\mathrm{q}^{\mathrm{L}}\left(\mathrm{dr} / \mathrm{dq}^{\mathrm{L}}\right) / \mathrm{r}$ that $\mathrm{d} \pi^{\mathrm{H}} / \mathrm{dq}^{\mathrm{H}}=4\left(\phi(\mathrm{r})+\alpha \mathrm{r} \phi^{\prime}(\mathrm{r})\right)-\lambda^{\mathrm{H}} \mathrm{F}^{\prime}\left(\mathrm{q}^{\mathrm{H}}\right)$ and hence that

$$
\mathrm{d}^{2} \pi^{\mathrm{H}} /\left(\mathrm{dq}^{\mathrm{H}}\right)^{2}=-\lambda^{\mathrm{H}} \mathrm{F}^{\prime \prime}\left(\mathrm{q}^{\mathrm{H}}\right)+4\left[\phi^{\prime}(\mathrm{r})(1+\alpha)+\alpha \mathrm{r} \phi^{\prime \prime}(\mathrm{r})\right]\left(\alpha / \mathrm{q}^{\mathrm{L}}\right)+4 \mathrm{r} \phi^{\prime}(\mathrm{r})\left(\mathrm{d} \alpha / \mathrm{dq}^{\mathrm{H}}\right) .
$$

Next, letting $\xi^{\mathrm{L}} \equiv-\lambda^{\mathrm{L}} \mathrm{F}^{\prime \prime \prime}\left(\mathrm{q}^{\mathrm{L}}\right) / \pi^{\mathrm{L}}{ }_{\mathrm{LL}}$ and using $\alpha=-\lambda^{\mathrm{L}} \mathrm{F}^{\prime \prime}\left(\mathrm{q}^{\mathrm{L}}\right) / \pi^{\mathrm{L}}{ }_{\mathrm{LL}}$ from (A.8), we obtain $\mathrm{d} \alpha / \mathrm{dq}^{\mathrm{H}}=(\alpha-$ $1)^{2} \xi^{\mathrm{L}} / \mathrm{r}-\alpha\left(\mathrm{dR}_{\mathrm{LL}}^{\mathrm{L}} / \mathrm{dq}^{\mathrm{H}}\right) / \pi^{\mathrm{L}}{ }_{\mathrm{LL}}$. From $\mathrm{R}_{\mathrm{LL}}^{\mathrm{L}}=-2(\mathrm{r})^{2}(8 \mathrm{r}+7) /(4 \mathrm{r}-1)^{4} \mathrm{q}^{\mathrm{L}}$ and $\mathrm{dq}^{\mathrm{L}} / \mathrm{dq}^{\mathrm{H}}=(1-\alpha) / \mathrm{r}$, we also have $\mathrm{dR}^{\mathrm{L}}{ }_{\mathrm{LL}} / \mathrm{dq}^{\mathrm{H}}$ $=\mathrm{R}_{\text {LLH }}^{\mathrm{L}}+\mathrm{R}_{\text {LLL }}^{\mathrm{L}}(1-\alpha) / \mathrm{r}$ where $\mathrm{R}_{\text {LLL }}^{\mathrm{L}}=-\left(\mathrm{R}_{\mathrm{LL}}^{\mathrm{L}} / \mathrm{q}^{\mathrm{L}}+\mathrm{rR}_{\mathrm{LLH}}^{\mathrm{L}}\right)$. Hence $\mathrm{dR}_{\mathrm{LL}}^{\mathrm{L}} / \mathrm{dq}^{\mathrm{H}}=-\mathrm{R}_{\mathrm{LL}}^{\mathrm{L}}(1-\alpha) / \mathrm{q}^{\mathrm{H}}+\alpha \mathrm{R}_{\mathrm{LLH}}^{\mathrm{L}}$ and using $\mathrm{R}^{\mathrm{L}}{ }_{\mathrm{LL}} / \pi^{\mathrm{L}}{ }_{\mathrm{LL}}=1-\alpha$ from (A.8), we obtain

$$
\mathrm{d} \alpha / \mathrm{dq}^{\mathrm{H}}=(1-\alpha)^{2}\left(\mathrm{q}^{\mathrm{L}} \xi^{\mathrm{L}}+\alpha\right) / \mathrm{q}^{\mathrm{H}}-(\alpha)^{2} \mathrm{R}_{\mathrm{LLH}}^{\mathrm{L}} / \pi^{\mathrm{L}}{ }_{\mathrm{LL}}
$$

for $\mathrm{R}_{\mathrm{LLH}}^{\mathrm{L}}=4 \mathrm{r}\left(16(\mathrm{r})^{2}+40 \mathrm{r}+7\right) /(4 \mathrm{r}-1)^{5}\left(\mathrm{q}^{\mathrm{L}}\right)^{2}$. Since $\left.\mathrm{dE} / \mathrm{dq}=\mathrm{F}^{\prime \prime}(\mathrm{q}) / \mathrm{F}^{\prime}(\mathrm{q})-\mathrm{q}\left(\mathrm{F}^{\prime \prime}(\mathrm{q})\right)^{2}-\mathrm{F}^{\prime}(\mathrm{q}) \mathrm{F}^{\prime \prime \prime}(\mathrm{q})\right) /\left(\mathrm{F}^{\prime}(\mathrm{q})\right)^{2}=0$ (from $\mathrm{E}$ constant), we obtain $\mathrm{qF}^{\prime \prime \prime}(\mathrm{q})-\mathrm{F}^{\prime \prime}(\mathrm{q})(\mathrm{E}-1)=0$, which implies $\mathrm{q}^{\mathrm{L}} \xi^{\mathrm{L}}-\alpha(\mathrm{E}-1)=0$ and hence, from (A.14), that $\mathrm{d} \alpha / \mathrm{dq}^{\mathrm{H}}=\alpha(1-\alpha)^{2} \mathrm{E} / \mathrm{q}^{\mathrm{H}}-(\alpha)^{2} \mathrm{R}_{\mathrm{LLH}}^{\mathrm{L}} / \pi^{\mathrm{L}}{ }_{\mathrm{LL}}$. Also, from $\lambda^{\mathrm{H}} \mathrm{F}^{\prime \prime}\left(\mathrm{q}^{\mathrm{H}}\right)=\mathrm{E} \lambda^{\mathrm{H}} \mathrm{F}^{\prime}\left(\mathrm{q}^{\mathrm{H}}\right) / \mathrm{q}^{\mathrm{H}}$ and $\mathrm{d} \pi^{\mathrm{H}} / \mathrm{dq} \mathrm{q}^{\mathrm{H}}=0$, we obtain $\lambda^{\mathrm{H}} \mathrm{F}^{\prime \prime}\left(\mathrm{q}^{\mathrm{H}}\right)=4 \mathrm{E}\left[\phi(\mathrm{r}) / \mathrm{q}^{\mathrm{H}}+\alpha \phi^{\prime}(\mathrm{r}) / \mathrm{q}^{\mathrm{L}}\right]$, which, using $\phi(\mathrm{r})>\mathrm{r} \phi^{\prime}(\mathrm{r})$ from $\pi_{\mathrm{L}}^{\mathrm{L}}=0$, implies $\lambda^{\mathrm{H}} \mathrm{F}^{\prime \prime}\left(\mathrm{q}^{\mathrm{H}}\right)$ $>4 \mathrm{E}(1+\alpha) \phi^{\prime}(\mathrm{r}) / \mathrm{q}^{\mathrm{L}}$. Letting $\mathrm{k}(\mathrm{r}) \equiv-\phi^{\prime \prime}(\mathrm{r}) / \mathrm{q}^{\mathrm{L}}+\phi^{\prime}(\mathrm{r}) \mathrm{R}_{\mathrm{LLH}}^{\mathrm{L}} / \pi^{\mathrm{L}}{ }_{\mathrm{LL}}$, it then follows from (A.13), using $1+\alpha-$ $\alpha(1+\alpha)=(1-\alpha)(1+\alpha)$ and $1+\alpha-\alpha(1-\alpha)=1+(\alpha)^{2}$ that

$$
\mathrm{d}^{2} \pi^{\mathrm{H}} /\left(\mathrm{dq}^{\mathrm{H}}\right)^{2}<-4 \phi^{\prime}(\mathrm{r})\left[(\mathrm{E}-1)\left(1+\alpha-\alpha(1-\alpha)^{2}\right)+(1-\alpha)\left(1+(\alpha)^{2}\right)\right] / \mathrm{q}^{\mathrm{L}}-4 \mathrm{r}(\alpha)^{2} \mathrm{k}(\mathrm{r}),
$$

which, using $\alpha>0,1-\alpha>0$ and $\mathrm{E} \geq 1$ (from $\mathrm{F}^{\prime \prime \prime}(\mathrm{q}) \geq 0$ ), implies $\mathrm{d}^{2} \pi^{\mathrm{H}} /\left(\mathrm{dq}^{\mathrm{H}}\right)^{2}<0$ if $\mathrm{k}(\mathrm{r}) \geq 0$. Since $\pi^{\mathrm{L}}{ }_{\mathrm{LL}}=$ $\mathrm{R}_{\mathrm{LL}}^{\mathrm{L}}-\lambda^{\mathrm{L}} \mathrm{F}^{\prime \prime}\left(\mathrm{q}^{\mathrm{L}}\right)<\mathrm{R}_{\mathrm{LL}}^{\mathrm{L}}$ and $\mathrm{R}_{\mathrm{LL}}^{\mathrm{L}}=(\mathrm{r})^{2} \phi^{\prime \prime}(\mathrm{r}) / \mathrm{q}^{\mathrm{L}}<-8(\mathrm{r})^{2} \phi^{\prime}(\mathrm{r}) /(4 \mathrm{r}-1) \mathrm{q}^{\mathrm{L}}$ from (9), we obtain $\mathrm{k}(\mathrm{r})>$ $\phi^{\prime}(\mathrm{r})\left[\left(8(\mathrm{r})^{2} \phi^{\prime \prime}(\mathrm{r})\right) /(4 \mathrm{r}-1)+\left(\mathrm{q}^{\mathrm{L}}\right)^{2} \mathrm{R}_{\mathrm{LLH}}^{\mathrm{L}}\right] /\left(\mathrm{q}^{\mathrm{L}}\right)^{2} \pi^{\mathrm{L}}{ }_{\mathrm{LL}}$ and hence, using $\phi^{\prime \prime}(\mathrm{r})=-2(8 \mathrm{r}+7) /(4 \mathrm{r}-1)^{4}$ and $\mathrm{r} \geq 7 / 4$, it follows that $\mathrm{k}(\mathrm{r})>-4 \mathrm{r} \phi^{\prime}(\mathrm{r})[16 \mathrm{r}(\mathrm{r}-1)+4 \mathrm{r}-7] /\left(\mathrm{q}^{\mathrm{L}}\right)^{2} \pi^{\mathrm{L}}{ }_{\mathrm{LL}}(4 \mathrm{r}-1)^{5}>0$.

Proposition 7. Under Bertrand competition, the jointly optimal policies $\left(s^{L J}, s^{H J}\right)$ involve an investment tax in the LDC and an investment subsidy in country $H$ : i.e. $s^{L J}=R_{L}^{H} / \gamma F^{\prime}\left(q^{L}\right)<0$ and $s^{H J}=R_{H^{L}}^{L} / F^{\prime}\left(q^{H}\right)>0$. Proof. Let $\mathrm{J}=\mathrm{J}\left(\mathrm{s}^{\mathrm{L}}, \mathrm{s}^{\mathrm{H}}\right)=\mathrm{W}^{\mathrm{L}}\left(\mathrm{s}^{\mathrm{L}}, \mathrm{s}^{\mathrm{H}}\right)+\mathrm{W}^{\mathrm{H}}\left(\mathrm{s}^{\mathrm{L}}, \mathrm{s}^{\mathrm{H}}\right)$ represent joint welfare, where $\mathrm{W}^{\mathrm{i}}\left(\mathrm{s}^{\mathrm{L}}, \mathrm{s}^{\mathrm{H}}\right)=\pi^{\mathrm{i}}\left(\mathrm{q}^{\mathrm{L}}, \mathrm{q}^{\mathrm{H}}, \lambda^{\mathrm{i}}\right)$ $s^{i} \gamma^{i} F\left(q^{i}\right)=R^{i}-\gamma^{i} F\left(q^{i}\right)$ for $\gamma^{L}=\gamma, \gamma^{H}=1$ and $i=L, H$. Using $\pi_{i}^{i}=0$ from (13), it then follows that $\mathrm{dW}^{i} / \mathrm{ds}^{\mathrm{i}}$

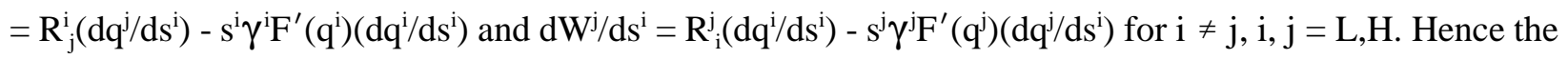
policies $\left(\mathrm{s}^{\mathrm{JL}}, \mathrm{s}^{\mathrm{HL}}\right)$ satisfy the first order conditions:

$$
\mathrm{d} J / d s^{\mathrm{L}}=\left(\mathrm{R}_{\mathrm{L}}^{\mathrm{H}}-\mathrm{s}^{\mathrm{L}} \gamma \mathrm{F}^{\prime}\left(\mathrm{q}^{\mathrm{L}}\right)\right)\left(\mathrm{dq} \mathrm{q}^{\mathrm{L}} / \mathrm{d} \mathrm{s}^{\mathrm{L}}\right)+\left(\mathrm{R}_{\mathrm{H}}^{\mathrm{L}}-\mathrm{s}^{\mathrm{H}} \mathrm{F}^{\prime}\left(\mathrm{q}^{\mathrm{H}}\right)\right)\left(\mathrm{dq}^{\mathrm{H}} / \mathrm{ds} \mathrm{s}^{\mathrm{L}}\right)=0
$$




$$
\mathrm{dJ} / \mathrm{ds}^{\mathrm{H}}=\left(\mathrm{R}_{\mathrm{L}}^{\mathrm{H}}-\mathrm{s}^{\mathrm{L}} \gamma \mathrm{F}^{\prime}\left(\mathrm{q}^{\mathrm{L}}\right)\right)\left(\mathrm{dq}^{\mathrm{L} / d s^{\mathrm{H}}}\right)+\left(\mathrm{R}_{\mathrm{H}}^{\mathrm{L}}-\mathrm{s}^{\mathrm{H}} \mathrm{F}^{\prime}\left(\mathrm{q}^{\mathrm{H}}\right)\right)\left(\mathrm{dq}^{\mathrm{H}} / \mathrm{ds}^{\mathrm{H}}\right)=0 .
$$

It then follows from (A.15), using $\mathrm{R}_{\mathrm{L}}^{\mathrm{H}}<0$ and $\mathrm{R}_{\mathrm{H}}^{\mathrm{L}}>0$ from (11), that

$$
\mathrm{s}^{\mathrm{LJ}}=\mathrm{R}_{\mathrm{L}}^{\mathrm{H}} / \gamma \mathrm{F}^{\prime}\left(\mathrm{q}^{\mathrm{L}}\right)<0 \text { and } \mathrm{s}^{\mathrm{HJ}}=\mathrm{R}_{\mathrm{H}^{\mathrm{L}}}^{\mathrm{L}} / \mathrm{F}^{\prime}\left(\mathrm{q}^{\mathrm{H}}\right)>0 .
$$

\section{Appendix B: Cournot Competition}

Lemma 3. Assuming Cournot competition, if $\lambda^{L} \geq \lambda^{H}$, then $q^{L}<q^{H}$.

Proof. Since $\psi(r)=4 \omega(r)-1 /(4 r-1)$ and $\psi^{\prime}(r)=-4 \omega^{\prime}(r)-4 /(4 r-1)$ from $(25)$, using $R_{L}^{\mathrm{cL}}=\omega(r)-r \omega^{\prime}(r)$ and $\mathrm{R}_{\mathrm{H}}^{\mathrm{cH}}=\psi(\mathrm{r})+\mathrm{r} \psi^{\prime}(\mathrm{r})$ from (29), we obtain

$$
\mathrm{R}_{\mathrm{H}}^{\mathrm{cH}}=4 \mathrm{R}_{\mathrm{L}}^{\mathrm{cL}}+1 /(4 \mathrm{r}-1)^{2}>\mathrm{R}_{\mathrm{L}}^{\mathrm{cL}} \text { for all } \mathrm{q}^{\mathrm{H}} \geq \mathrm{q}^{\mathrm{L}}>0 .
$$

At the Nash equilibrium $\mathrm{q}^{\mathrm{L}}>0$ satisfies the first order condition $\Pi_{\mathrm{L}}^{\mathrm{L}}=\mathrm{R}_{\mathrm{L}^{-}}^{\mathrm{cL}} \lambda^{\mathrm{L}} \mathrm{F}^{\prime}\left(\mathrm{q}^{\mathrm{L}}\right)=0$. If $\lambda^{\mathrm{L}} \geq \lambda^{\mathrm{H}}$ and $\mathrm{q}^{\mathrm{H}}=\mathrm{q}^{\mathrm{L}}$, then using (B.1), we obtain $\Pi_{\mathrm{H}}^{\mathrm{H}}=\mathrm{R}_{\mathrm{H}}^{\mathrm{cH}}-\lambda^{\mathrm{H}} \mathrm{F}^{\prime}\left(\mathrm{q}^{\mathrm{H}}\right)>\Pi_{\mathrm{L}}^{\mathrm{L}}=0$, proving that $\mathrm{q}^{\mathrm{H}}>\mathrm{q}^{\mathrm{L}}$.

Lemma 4. Assume Cournot competition and conditions (1). Then $\Pi_{L L}^{L}<0, \Pi_{H H}^{H}<0$ and $D^{c} \equiv \Pi_{L L}^{L} \Pi_{H H}^{H}$ - $\Pi_{L H}^{L} \Pi_{H L}^{H}>0$ are satisfied at $\Pi_{L}^{L}=0$ : (i) if $\Pi_{H}^{H}=0, F^{\prime \prime \prime}(q)=0$ and $\lambda^{L} / \lambda^{H} \geq 1$ or (ii) if $E^{L} \geq 2$.

Proof: We first prove $\Pi^{\mathrm{L}}{ }_{\mathrm{LL}}<0$ for both cases (i) and (ii). Using (30), (31) and $\mathrm{E} \equiv \mathrm{qF} \mathrm{F}^{\prime \prime}(\mathrm{q}) / \mathrm{F}^{\prime}(\mathrm{q})$, we obtain

$$
\Pi_{L L}^{L}=R_{L L}^{c L}-\lambda^{L} F^{\prime \prime}\left(q^{L}\right)=\left[(r)^{2} \omega^{\prime \prime}(r)-\lambda^{L} F^{\prime}\left(q^{L}\right) E^{L}\right] / q^{L} .
$$

(i) If $\mathrm{F}^{\prime \prime \prime}(\mathrm{q})=0$, then $\mathrm{F}^{\prime \prime}(\mathrm{q})$ is a constant and since $\mathrm{F}^{\prime}(0)=0$ from $(1)$, we have $E=q F^{\prime \prime}(\mathrm{q}) / \mathrm{F}^{\prime}(\mathrm{q})=1$ and $\mathrm{F}^{\prime}\left(\mathrm{q}^{\mathrm{H}}\right)-\mathrm{F}^{\prime}\left(\mathrm{q}^{\mathrm{L}}\right)=\mathrm{F}^{\prime \prime}\left(\mathrm{q}^{\mathrm{H}}\right)\left(\mathrm{q}^{\mathrm{H}}-\mathrm{q}^{\mathrm{L}}\right)=\mathrm{EF}^{\prime}\left(\mathrm{q}^{\mathrm{H}}\right)(1-1 / \mathrm{r})$, which implies $\mathrm{F}^{\prime}\left(\mathrm{q}^{\mathrm{L}}\right) / \mathrm{F}^{\prime}\left(\mathrm{q}^{\mathrm{H}}\right)=1 / \mathrm{r}$. Using $\mathrm{R}_{\mathrm{L}}^{\mathrm{cL}} / \mathrm{R}_{\mathrm{H}}^{\mathrm{cH}}=$ $\lambda^{\mathrm{L}} \mathrm{F}^{\prime}\left(\mathrm{q}^{\mathrm{L}}\right) / \lambda^{\mathrm{H}} \mathrm{F}^{\prime}\left(\mathrm{q}^{\mathrm{H}}\right)$ from $\Pi_{\mathrm{L}}^{\mathrm{L}}=\Pi_{\mathrm{H}}^{\mathrm{H}}=0$, we then obtain $\lambda^{\mathrm{L}} \mathrm{F}^{\prime}\left(\mathrm{q}^{\mathrm{L}}\right)=\mathrm{R}_{\mathrm{L}}^{\mathrm{cL}}=\left(\mathrm{R}_{\mathrm{H}}^{\mathrm{cH}} / \mathrm{r}\right)\left(\lambda^{\mathrm{L}} / \lambda^{\mathrm{H}}\right) \geq \mathrm{R}^{\mathrm{cH}} / \mathrm{r}$ for $\lambda^{\mathrm{L}} / \lambda^{\mathrm{H}}$ $\geq 1$. Hence it follows from (B.2), that $\Pi_{\mathrm{LL}}^{\mathrm{L}}<0$ if $(\mathrm{r})^{2} \omega^{\prime \prime}(\mathrm{r})-\mathrm{R}_{\mathrm{H}}^{\mathrm{cH}} / \mathrm{r}<0$. Using $\omega^{\prime \prime}(\mathrm{r})=2(8 \mathrm{r}+1) /(4 \mathrm{r}-1)^{4}$ and $\mathrm{R}_{\mathrm{H}}^{\mathrm{cH}}=\left(16(\mathrm{r})^{3}-12(\mathrm{r})^{2}+4 \mathrm{r}-1\right) /(4 \mathrm{r}-1)^{3}$ we can then show

$$
(r)^{2} \omega^{\prime \prime}(r)-R_{H}^{\mathrm{cH}} / r=-\left[(r)^{2}(r-1)(48 r-18)+10(r)^{2}-8 r+1\right] / r(4 r-1)^{4}<0 \text { for all } r \geq 1 .
$$

(ii) From (29), (31) and $r \geq 1$, a useful expression is:

$$
\mathrm{U}(\mathrm{r}) \equiv 2 \omega(\mathrm{r})-(\mathrm{r})^{2} \omega^{\prime \prime}(\mathrm{r})=32(\mathrm{r})^{3}(\mathrm{r}-1) /(4 \mathrm{r}-1)^{4} \geq 0 .
$$

Since $\lambda^{\mathrm{L}} \mathrm{F}^{\prime}\left(\mathrm{q}^{\mathrm{L}}\right)=\omega(\mathrm{r})-\mathrm{r} \omega^{\prime}(\mathrm{r})$ from $\Pi_{\mathrm{L}}^{\mathrm{L}}=0$, from (B.2), using $\mathrm{E}^{\mathrm{L}} \geq 2$, (B.3) and $\omega^{\prime}(\mathrm{r})<0$, we obtain $\Pi_{\mathrm{LL}}^{\mathrm{L}}$ 
$=-\left[\mathrm{v}(\mathrm{r})+\omega(\mathrm{r})(\mathrm{E}-2)-\mathrm{r} \omega^{\prime}(\mathrm{r}) \mathrm{E}\right] / \mathrm{q}^{\mathrm{L}}<0$. Next for both cases (i) and (ii) using $\Pi_{\mathrm{HH}}^{\mathrm{H}}=\mathrm{R}_{\mathrm{HH}}^{\mathrm{cH}}-\lambda^{\mathrm{H}} \mathrm{F}^{\prime \prime}\left(\mathrm{q}^{\mathrm{H}}\right), \mathrm{R}^{\mathrm{cH}}{ }_{\mathrm{HH}}$ $\leq 0, \mathrm{~F}^{\prime \prime}(\mathrm{q})>0$ and $\mathrm{R}_{\mathrm{LL}}^{\mathrm{cL}} \mathrm{R}_{\mathrm{HH}}^{\mathrm{cH}}-\mathrm{R}_{\mathrm{LH}}^{\mathrm{cL}} \mathrm{R}_{\mathrm{HL}}^{\mathrm{cH}}=0$ from (32), we obtain:

$$
\Pi_{\mathrm{LL}}^{\mathrm{L}}<0, \Pi_{\mathrm{HH}}^{\mathrm{H}}<0, \mathrm{D}^{\mathrm{c}}=-\lambda^{\mathrm{H}} \mathrm{F}^{\prime \prime}\left(\mathrm{q}^{\mathrm{H}}\right) \Pi_{\mathrm{LL}}^{\mathrm{L}}-\lambda^{\mathrm{L}} \mathrm{F}^{\prime \prime}\left(\mathrm{q}^{\mathrm{L}}\right) \mathrm{R}_{\mathrm{HH}}^{\mathrm{cH}}>0 .
$$

Effects of $\lambda^{\mathrm{L}}$ and $\lambda^{\mathrm{H}}$ on quality levels: Letting $\mathrm{q}^{\mathrm{L}}=\mathrm{q}^{\mathrm{cL}}\left(\lambda^{\mathrm{L}}, \lambda^{\mathrm{H}}\right)$ and $\mathrm{q}^{\mathrm{H}}=\mathrm{q}^{\mathrm{cH}}\left(\lambda^{\mathrm{L}}, \lambda^{\mathrm{H}}\right)$ denote the Nashquality levels, from (28) using (B.4) and (32) to sign expressions, we obtain:

$$
\begin{aligned}
& \mathrm{dq} / \mathrm{d} \lambda^{\mathrm{L}}=\mathrm{F}^{\prime}\left(\mathrm{q}^{\mathrm{L}}\right) \Pi_{\mathrm{HH}}^{\mathrm{H}} / \mathrm{D}^{\mathrm{c}}<0, \mathrm{dq}^{\mathrm{H}} / \mathrm{d} \lambda^{\mathrm{L}}=-\mathrm{F}^{\prime}\left(\mathrm{q}^{\mathrm{L}}\right) \mathrm{R}^{\mathrm{cH}}{ }_{\mathrm{HL}} / \mathrm{D}^{\mathrm{c}}<0 ; \\
& \mathrm{dq}^{\mathrm{H}} / \mathrm{d} \lambda^{\mathrm{H}}=\mathrm{F}^{\prime}\left(\mathrm{q}^{\mathrm{H}}\right) \Pi_{\mathrm{LL}}^{\mathrm{L}} / \mathrm{D}^{\mathrm{c}}<0, \mathrm{dq} / \mathrm{d} \lambda^{\mathrm{H}}=-\mathrm{F}^{\prime}\left(\mathrm{q}^{\mathrm{H}}\right) \mathrm{R}^{\mathrm{cL}}{ }_{\mathrm{LH}} / \mathrm{D}^{\mathrm{c}}>0,
\end{aligned}
$$

where $\mathrm{D}^{\mathrm{c}} \equiv \Pi_{\mathrm{LL}}^{\mathrm{L}} \Pi_{\mathrm{HH}}^{\mathrm{H}}-\Pi_{\mathrm{LH}}^{\mathrm{L}} \Pi_{\mathrm{HL}}^{\mathrm{H}}>0$ from (B.4).

We next show in Lemma 5 that the profits of firm $L$ fall in response to an increase in own cost $\lambda^{L}$.

Lemma 5. Assuming conditions (1) and $\Pi_{L L}^{L}<0$, then $d \Pi^{L} / d \lambda^{L}<0$.

Proof. Since $\mathrm{d} \Pi^{\mathrm{L}} / \mathrm{d} \lambda^{\mathrm{L}}=\mathrm{R}^{\mathrm{cL}}{ }_{\mathrm{H}}\left(\mathrm{dq}^{\mathrm{H}} / \mathrm{d} \lambda^{\mathrm{L}}\right)-\mathrm{F}\left(\mathrm{q}^{\mathrm{cL}}\right)$ (from (27) and (28)), using $\mathrm{dq}^{\mathrm{H}} / \mathrm{d}^{\mathrm{L}}=\mathrm{rR}^{\mathrm{cH}}{ }_{\mathrm{HH}} \mathrm{F}^{\prime}\left(\mathrm{q}^{\mathrm{L}}\right) / \mathrm{D}^{\mathrm{c}}<0$ (from (B.5) and (32)) we obtain $\mathrm{d} \Pi \Pi^{\mathrm{L}} / \mathrm{d} \lambda^{\mathrm{L}}=\left[\mathrm{R}^{\mathrm{cH}}{ }_{\mathrm{HH}} \mathrm{rR}^{\mathrm{cL}}{ }_{\mathrm{H}} \mathrm{F}^{\prime}\left(\mathrm{q}^{\mathrm{L}}\right)-\mathrm{D}^{\mathrm{c}} \mathrm{F}\left(\mathrm{q}^{\mathrm{L}}\right)\right] / \mathrm{D}^{\mathrm{c}}$. From $\mathrm{D}^{\mathrm{c}}$ as in (B.4), $\Pi_{\mathrm{LL}}^{\mathrm{L}}<0$ (see Lemma 4) and $\mathrm{R}_{\mathrm{HH}}^{\mathrm{cH}}<0$ (see (31)), it follows letting $\mathrm{Z}^{\mathrm{c}} \equiv \mathrm{rR}_{\mathrm{H}^{\mathrm{cL}}} \mathrm{F}^{\prime}\left(\mathrm{q}^{\mathrm{L}}\right)+\lambda^{\mathrm{L}} \mathrm{F}^{\prime \prime}\left(\mathrm{q}^{\mathrm{L}}\right) \mathrm{F}\left(\mathrm{q}^{\mathrm{L}}\right)$ that

$$
\mathrm{d} \Pi \mathrm{L} / \mathrm{d} \lambda^{\mathrm{L}}=\left[\mathrm{R}_{\mathrm{HH}}^{\mathrm{cH}} \mathrm{Z}^{\mathrm{c}}+\lambda^{\mathrm{H}} \mathrm{F}^{\prime \prime}\left(\mathrm{q}^{\mathrm{H}}\right) \mathrm{F}\left(\mathrm{q}^{\mathrm{L}}\right) \Pi_{\mathrm{LL}}^{\mathrm{L}}\right] / \mathrm{D}^{\mathrm{c}}<0 \text { if } \mathrm{Z}^{\mathrm{c}} \geq 0 .
$$

Since from (26), (29) and (28), $\mathrm{R}_{\mathrm{L}}^{\mathrm{cL}}=-2 \mathrm{R}_{\mathrm{H}}^{\mathrm{cL}}(\mathrm{r})^{2}+(\mathrm{r})^{2} /(4 \mathrm{r}-1)^{3}=\lambda^{\mathrm{L}} \mathrm{F}^{\prime}\left(\mathrm{q}^{\mathrm{cL}}\right)$, we obtain $\mathrm{R}_{\mathrm{H}}^{\mathrm{cL}}=-\lambda^{\mathrm{L}} \mathrm{F}^{\prime}\left(\mathrm{q}^{\mathrm{L}}\right) / 2(\mathrm{r})^{2}$ $+1 / 2(4 \mathrm{r}-1)^{3}$. Using $\mathrm{T}(\mathrm{q}) \equiv 2 \mathrm{~F}^{\prime \prime}(\mathrm{q}) \mathrm{F}(\mathrm{q})-\left(\mathrm{F}^{\prime}(\mathrm{q})\right)^{2}>0$ from $\mathrm{F}^{\prime \prime \prime}(\mathrm{q}) \geq 0$ (see $($ A.2) $)$, we obtain $\mathrm{Z}^{\mathrm{c}}=\lambda^{\mathrm{L}} \mathrm{T}\left(\mathrm{q}^{\mathrm{L}}\right) / 2$ $+(\mathrm{r}-1) \lambda^{\mathrm{L}}\left(\mathrm{F}^{\prime}\left(\mathrm{q}^{\mathrm{L}}\right)\right)^{2} / 2 \mathrm{r}+\mathrm{rF}^{\prime}\left(\mathrm{q}^{\mathrm{L}}\right) / 2(4 \mathrm{r}-1)^{3}>0$.

Proposition 9. Assume Cournot output competition. Under conditions (1), if $\gamma \geq 1$ is sufficiently large, there exists a unique pure strategy equilibrium in which the low quality is produced in the LDC and the high quality is produced in the developed country.

Proof. Suppose firm $i$ for $i=1,2$ faces an investment cost $\gamma^{i}$. For any quality $q^{j}$ set by firm $j$, the profits of firm $\mathrm{i}$ for $\mathrm{i} \neq \mathrm{j}$ and $\mathrm{i}, \mathrm{j}=1,2$ are given by $\Pi^{\mathrm{iL}}$ if it is the low quality producer and $\Pi^{\mathrm{iH}}$ if it is the high quality producer. Since $\lambda^{\mathrm{L}}=\gamma^{\mathrm{i}}$ if $\mathrm{q}^{\mathrm{i}}=\mathrm{q}^{\mathrm{iL}}$ and $\lambda^{\mathrm{H}}=\gamma^{\mathrm{i}}$ if $\mathrm{q}^{\mathrm{i}}=\mathrm{q}^{\mathrm{iH}}$, from (27), we obtain:

$$
\begin{aligned}
& \Pi^{i L}=\Pi^{L}\left(q^{i L}, q^{j} ; \gamma^{i}\right)=R^{c i L}-\gamma^{i} F\left(q^{i L}\right) \text { for } R^{c i L}=\omega\left(r^{i L}\right) q^{i L} \text { and } r^{i L} \equiv q^{j} / q^{i L} ; \\
& \Pi^{i H}=\Pi^{H}\left(q^{j}, q^{i H} ; \gamma^{i}\right)=R^{c i H}-\gamma^{i} F\left(q^{i H}\right) \text { for } R^{c i H}=\psi\left(r^{i H}\right) q^{i H} \text { and } r^{i H} \equiv q^{i H} / q^{j} .
\end{aligned}
$$

We assume that $\mathrm{q}^{\mathrm{iL}}<\mathrm{q}^{\mathrm{j}}$ and $\mathrm{q}^{\mathrm{iH}}>\mathrm{q}^{\mathrm{j}}$ are at their profit maximizing levels for a given $\mathrm{q}^{\mathrm{j}}$ and hence satisfy the 
reaction functions $\mathrm{q}^{\mathrm{iL}}=\rho^{\mathrm{cL}}\left(\mathrm{q}^{\mathrm{j}}, \gamma^{\mathrm{i}}\right)$ and $\mathrm{q}^{\mathrm{iH}}=\rho^{\mathrm{cH}}\left(\mathrm{q}^{\mathrm{j}}, \gamma^{\mathrm{i}}\right)$ defined respectively by:

$$
\Pi_{\mathrm{L}}^{\mathrm{iL}}=\mathrm{R}_{\mathrm{L}}^{\mathrm{ciL}}-\gamma^{\mathrm{i}} \mathrm{F}^{\prime}\left(\mathrm{q}^{\mathrm{iL}}\right)=0 \text { and } \Pi_{\mathrm{H}}^{\mathrm{iH}}=\mathrm{R}_{\mathrm{H}}^{\mathrm{ciH}}-\gamma^{\mathrm{i}} \mathrm{F}^{\prime}\left(\mathrm{q}^{\mathrm{iH}}\right)=0 \text {, }
$$

where $\mathrm{R}_{\mathrm{L}}^{\mathrm{ciL}}=\omega\left(\mathrm{r}^{\mathrm{iL}}\right)-\mathrm{r}^{\mathrm{iL}} \omega^{\prime}\left(\mathrm{r}^{\mathrm{iL}}\right)$ and $\mathrm{R}_{\mathrm{H}}^{\mathrm{ciH}}=\psi\left(\mathrm{r}^{\mathrm{iH}}\right)+\mathrm{r}^{\mathrm{iH}} \psi^{\prime}\left(\mathrm{r}^{\mathrm{iH}}\right)$. From Lemma 4 , there are only two potential equilibria, $\left(\mathrm{q}^{1 \mathrm{~L}}, \mathrm{q}^{2 \mathrm{H}}\right)$ and the "switched" equilibrium, $\left(\mathrm{q}^{2 \mathrm{~L}}, \mathrm{q}^{1 \mathrm{H}}\right)$.

Since $\mathrm{R}_{\mathrm{L}}^{\mathrm{ciL}}>0$ for $\mathrm{q}^{\mathrm{iL}}>0$ (see (29)), using $\mathrm{F}^{\prime}(0)=0$ from (1) and $\Pi_{\mathrm{L}}^{\mathrm{iL}}=\mathrm{R}_{\mathrm{L}}^{\mathrm{ciL}}-\gamma^{\mathrm{i}} \mathrm{F}^{\prime}\left(\mathrm{q}^{\mathrm{iL}}\right)$, we obtain $\lim _{q^{L} \rightarrow 0} \Pi^{\mathrm{iL}}{ }_{\mathrm{L}}>0$, which implies that, for any $\mathrm{q}^{\mathrm{j}}$ and $\gamma^{\mathrm{i}}, \Pi^{\mathrm{iL}}>0$ if $\mathrm{q}^{\mathrm{iL}}$ is sufficiently small. Thus, if firm $i$ is firm $L$, then $\Pi^{i L}>0$ if $q^{i L}$ is chosen optimally at $q^{i L}=\rho^{c L}\left(q^{j}, \gamma^{i}\right)$. Alternatively, if firm $i$ is firm $H$, from (B.6), using $\omega(\mathrm{r})=(\mathrm{r})^{2} /(4 \mathrm{r}-1)^{2}$ and $\psi(\mathrm{r})=(2 \mathrm{r}-1)^{2} /(4 \mathrm{r}-1)^{2}$, we obtain $\mathrm{R}^{\mathrm{ciH}}-\mathrm{R}^{\mathrm{cjL}}=\mathrm{q}^{\mathrm{iH}}(\mathrm{r}-1)(4 \mathrm{r}-1)$ for $\mathrm{r}=$

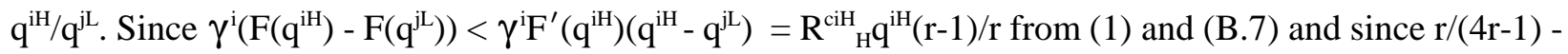
$\mathrm{R}_{\mathrm{H}}^{\mathrm{ciH}}=\left(4(\mathrm{r})^{2}-3 \mathrm{r}+1\right) /(4 \mathrm{r}-1)^{3} \geq 0$ from (29) and $\gamma^{1} \geq \gamma^{2}$, this implies

$$
\Pi^{\mathrm{iH}}-\Pi^{\mathrm{jL}}>\mathrm{q}^{\mathrm{iH}}(\mathrm{r}-1)\left[\mathrm{r} /(4 \mathrm{r}-1)-\mathrm{R}_{\mathrm{H}}^{\mathrm{ciH}}\right] / \mathrm{r}+\left(\gamma^{\mathrm{j}}-\gamma^{\mathrm{i}}\right) \mathrm{F}\left(\mathrm{q}^{\mathrm{j} \mathrm{L}}\right)>0 \text { for } \gamma^{\mathrm{j}}-\gamma^{\mathrm{i}} \geq 0 \text {. }
$$

Thus, for $\gamma^{1} \geq \gamma^{2}$, we have $\Pi^{2 \mathrm{H}}>\Pi^{1 \mathrm{~L}}>0$.

Next, let $\Delta^{\mathrm{ci}}=\Delta^{\mathrm{c}}\left(\mathrm{q}^{\mathrm{j}}, \gamma^{\mathrm{i}}\right) \equiv \Pi^{\mathrm{iL}}\left(\rho^{\mathrm{cL}}\left(\mathrm{q}^{\mathrm{j}}, \gamma^{\mathrm{i}}\right), \mathrm{q}^{\mathrm{j}}, \gamma^{\mathrm{i}}\right)-\Pi^{\mathrm{iH}}\left(\mathrm{q}^{\mathrm{j}}, \rho^{\mathrm{cH}}\left(\mathrm{q}^{\mathrm{j}}, \gamma^{\mathrm{i}}\right), \gamma^{\mathrm{i}}\right)$ represent the difference in profit earned by firm i from production of $\mathrm{q}^{\mathrm{iL}}$ rather than $\mathrm{q}^{\mathrm{iH}}$ for any given quality $\mathrm{q}^{\mathrm{j}}$ set by the other firm. For global stability of $\left(\mathrm{q}^{1 \mathrm{~L}}, \mathrm{q}^{2 \mathrm{H}}\right)$, we require $\Delta^{\mathrm{c} 1}=\Delta^{\mathrm{c}}\left(\mathrm{q}^{2 \mathrm{H}}, \gamma^{1}\right)>0$ for $\mathrm{q}^{2 \mathrm{H}}=\rho^{\mathrm{cH}}\left(\mathrm{q}^{1 \mathrm{~L}}, \gamma^{2}\right)$ and $\Delta^{\mathrm{c} 2}=\Delta^{\mathrm{c}}\left(\mathrm{q}^{1 \mathrm{~L}}, \gamma^{2}\right)<$ 0 for $\mathrm{q}^{1 \mathrm{~L}}=\rho^{\mathrm{cL}}\left(\mathrm{q}^{2 \mathrm{H}}, \gamma^{1}\right)$. Conversely, the switched equilibrium is not globally stable if $\Delta^{\mathrm{c} 1}=\Delta^{\mathrm{c}}\left(\mathrm{q}^{2 \mathrm{~L}}, \gamma^{1}\right)<0$ for $\mathrm{q}^{2 \mathrm{~L}}=\rho^{\mathrm{cL}}\left(\mathrm{q}^{1 \mathrm{H}}, \gamma^{2}\right)$ or if $\Delta^{\mathrm{c} 2}=\Delta^{\mathrm{c}}\left(\mathrm{q}^{1 \mathrm{H}}, \gamma^{2}\right)>0$ for $\mathrm{q}^{1 \mathrm{H}}=\rho^{\mathrm{cH}}\left(\mathrm{q}^{2 \mathrm{~L}}, \gamma^{1}\right)$.

To obtain these results, we first use (B.6) to express $\Delta^{\mathrm{ci}}$ in the form: $\Delta^{\mathrm{ci}}=\Delta^{\mathrm{c}}\left(\mathrm{q}^{\mathrm{j}}, \gamma^{\mathrm{i}}\right)=\omega\left(\mathrm{r}^{\mathrm{iL}}\right) \mathrm{q}^{\mathrm{iL}}$ $\psi\left(r^{i H}\right) q^{i H}+\gamma^{i}\left[F\left(q^{i H}\right)-F\left(q^{i L}\right)\right]$. Allowing $r^{i L} \equiv q^{j} / q^{i L}$ for $q^{i L}=\rho^{L}\left(q^{j}, \gamma^{i}\right)$ and $r^{i H} \equiv q^{i H} / q^{j}$ for $q^{i H}=\rho^{H}\left(q^{j}, \gamma^{i}\right)$ to vary using (B.7), this implies:

$$
\partial \Delta^{\mathrm{ci}} / \partial \gamma^{\mathrm{i}}=\mathrm{F}\left(\mathrm{q}^{\mathrm{iH}}\right)-\mathrm{F}\left(\mathrm{q}^{\mathrm{iL}}\right)>0 .
$$

We also obtain $\mathrm{d} \Delta^{\mathrm{ci}} / \mathrm{d} q^{\mathrm{j}}=\omega^{\prime}\left(\mathrm{r}^{\mathrm{iL}}\right)+\left(\mathrm{r}^{\mathrm{iH}}\right)^{2} \psi^{\prime}\left(\mathrm{r}^{\mathrm{iH}}\right)$. Since Min $\left[\omega^{\prime}\left(\mathrm{r}^{\mathrm{iL}}\right)\right]=\omega^{\prime}(1)=-2 / 27$ while $\operatorname{Min}\left[\left(\mathrm{r}^{\mathrm{iH}}\right)^{2}\right.$ $\left.\psi^{\prime}\left(\mathrm{r}^{\mathrm{iH}}\right)\right]=1 / 8($ reached as $\mathrm{r} \rightarrow \infty)$, we have

$$
\mathrm{d} \Delta^{\mathrm{ci}} / \mathrm{dq}^{\mathrm{j}}>\operatorname{Min}\left[\omega^{\prime}\left(\mathrm{r}^{\mathrm{iL}}\right)\right]+\operatorname{Min}\left[\left(\mathrm{r}^{\mathrm{iH}}\right)^{2} \psi^{\prime}\left(\mathrm{r}^{\mathrm{iH}}\right)\right]>-2 / 27+1 / 8>0 .
$$

With respect to firm 1, from (B.6) and (B.7), we obtain $\Pi^{1 \mathrm{H}}=-\mathrm{r}^{1 \mathrm{H}} \psi^{\prime}\left(\mathrm{r}^{1 \mathrm{H}}\right) \mathrm{q}^{1 \mathrm{H}}+\gamma^{1}\left[\mathrm{q}^{1 \mathrm{H}} \mathrm{F}^{\prime}\left(\mathrm{q}^{1 \mathrm{H}}\right)-\mathrm{F}\left(\mathrm{q}^{1 \mathrm{H}}\right)\right]$. Since 
$\mathrm{q}^{1 \mathrm{H}} \mathrm{F}^{\prime}\left(\mathrm{q}^{1 \mathrm{H}}\right)-\mathrm{F}\left(\mathrm{q}^{1 \mathrm{H}}\right)>0$ from $(1)$, this implies that $\Pi^{1 \mathrm{H}}=0$ for $\gamma^{1}=\gamma^{1 \mathrm{H}}\left(\mathrm{q}^{2}\right)=\mathrm{r}^{1 \mathrm{H}} \psi^{\prime}\left(\mathrm{r}^{1 \mathrm{H}}\right) \mathrm{q}^{1 \mathrm{H}} /\left[\mathrm{q}^{1 \mathrm{H}} \mathrm{F}^{\prime}\left(\mathrm{q}^{1 \mathrm{H}}\right)\right.$ $\left.\mathrm{F}\left(\mathrm{q}^{1 \mathrm{H}}\right)\right]>0$. Then, since $\mathrm{d} \Pi^{1 \mathrm{H}} / \mathrm{d} \gamma^{1}=\mathrm{R}_{\mathrm{L}}^{\mathrm{cH}}\left(\mathrm{dq} \mathrm{q}^{2 \mathrm{~L}} / \mathrm{d} \gamma^{1}\right)-\mathrm{F}\left(\mathrm{q}^{1 \mathrm{H}}\right)<0$ from $\mathrm{R}_{\mathrm{L}}^{\mathrm{cH}}<0$ and (B.5), setting $\mathrm{q}^{2}=\mathrm{q}^{2 \mathrm{~L}}=$ $\mathrm{q}^{\mathrm{L}}\left(\gamma^{2}, \gamma^{1}\right)$, it follows that $\Pi^{1 \mathrm{H}}<0$ and hence (using $\left.\Pi^{\mathrm{iL}}>0\right)$ that $\Delta^{1}\left(\mathrm{q}^{2 \mathrm{~L}}, \gamma^{1}\right)>0$ for $\gamma^{1}>\gamma^{1 \mathrm{H}}\left(\mathrm{q}^{2 \mathrm{~L}}\right)$. Thus firm 1 will set $\mathrm{q}^{1}<\mathrm{q}^{2 \mathrm{~L}}$, breaking the switched equilibrium $\left(\mathrm{q}^{2 \mathrm{~L}}, \mathrm{q}^{1 \mathrm{H}}\right)$ for $\gamma^{1}>\gamma^{1 \mathrm{H}}\left(\mathrm{q}^{2 \mathrm{~L}}\right)$. Alternatively, if $\mathrm{q}^{2}=\mathrm{q}^{2 \mathrm{H}}=$ $\mathrm{q}^{\mathrm{H}}\left(\gamma^{1}, \gamma^{2}\right)$, then since $\mathrm{q}^{2 \mathrm{H}}>\mathrm{q}^{2 \mathrm{~L}}$ and $\mathrm{d} \Delta^{\mathrm{c} 1} / \mathrm{dq}^{2}>0$ from (B.10), it follows that $\Delta^{\mathrm{cl}}\left(\mathrm{q}^{2 \mathrm{H}}, \gamma^{1}\right)>0$ for $\gamma^{1}>\gamma^{1 \mathrm{H}}\left(\mathrm{q}^{2 \mathrm{~L}}\right)$, and hence $\left(\mathrm{q}^{1 \mathrm{~L}}, \mathrm{q}^{2 \mathrm{H}}\right)$ is globally stable for firm 1. For firm 2 , if $\gamma^{1}=\gamma^{2}$, then $\Delta^{\mathrm{c} 2}=\Delta^{\mathrm{c}}\left(\mathrm{q}^{1 \mathrm{~L}}, \gamma^{2}\right)<0$, since $\Pi^{2 \mathrm{~L}}\left(\rho^{\mathrm{L}}\left(\mathrm{q}^{1 \mathrm{~L}}, \gamma^{2}\right), \mathrm{q}^{1 \mathrm{~L}}, \gamma^{2}\right)<\Pi^{2 \mathrm{~L}}\left(\rho^{\mathrm{L}}\left(\mathrm{q}^{1 \mathrm{H}}, \gamma^{2}\right), \mathrm{q}^{1 \mathrm{H}}, \gamma^{2}\right)<\Pi^{2 \mathrm{H}}\left(\mathrm{q}^{1 \mathrm{~L}}, \rho^{\mathrm{H}}\left(\mathrm{q}^{2 \mathrm{~L}}, \gamma^{2}\right), \gamma^{2}\right)$ where the first inequality follows from $\mathrm{d} \Pi^{2 \mathrm{~L}} / \mathrm{dq}^{1}>0$ and the second from (B.8). Since $\mathrm{dq}{ }^{1 \mathrm{~L}} / \mathrm{d} \gamma^{1}<0$ and $\mathrm{d} \Delta^{\mathrm{c} 2} / \mathrm{d} \gamma^{1}=\left(\mathrm{d} \Delta^{\mathrm{c} 2} / \mathrm{dq}{ }^{1 \mathrm{~L}}\right)\left(\mathrm{dq} \mathrm{q}^{1 \mathrm{~L}} / \mathrm{d} \gamma^{1}\right)<$ 0 , this implies $\Delta^{\mathrm{c} 2}=\Delta^{\mathrm{c}}\left(\mathrm{q}^{1 \mathrm{~L}}, \gamma^{2}\right)<0$ for all $\gamma^{1} \geq \gamma^{2}$ and hence that $\left(\mathrm{q}^{1 \mathrm{~L}}, \mathrm{q}^{2 \mathrm{H}}\right)$ is stable for firm 2 .

Lemma 6: Assume Cournot competition and conditions (1). Sufficient conditions to ensure local concavity of firm L's profit as a Stackelberg leader in quality space or equivalently, local concavity of LDC welfare, $W^{c L}$ with respect to $s^{L}$ are $E^{L} \equiv q^{L} F^{\prime \prime}\left(q^{L}\right) / F^{\prime}\left(q^{L}\right) \geq 2$ and $\sigma(q) \equiv\left(F^{\prime \prime}(q)\right)^{2}-F^{\prime}(q) F^{\prime \prime \prime}(q) \geq 0$.

Proof: Since, analogous to (21), $\mathrm{W}^{\mathrm{cL}}=\Pi^{\mathrm{L}}\left(\mathrm{q}^{\mathrm{L}}, \mathrm{q}^{\mathrm{H}}, \gamma\right)$ for $\mathrm{q}^{\mathrm{H}}=\rho^{\mathrm{cH}}\left(\mathrm{q}^{\mathrm{L}}\right)$ where $\Pi^{\mathrm{L}}\left(\mathrm{q}^{\mathrm{L}}, \mathrm{q}^{\mathrm{H}}, \gamma\right)=\mathrm{R}^{\mathrm{L}}\left(\mathrm{q}^{\mathrm{L}}, \mathrm{q}^{\mathrm{H}}\right)-\gamma \mathrm{F}\left(\mathrm{q}^{\mathrm{L}}\right)$ is firm L's profit at $s^{\mathrm{L}}=0$, as in the proof of Proposition 4, we obtain $\mathrm{d}^{2} \mathrm{~W}^{\mathrm{c}} /\left(\mathrm{ds}^{\mathrm{L}}\right)^{2}=\left(\mathrm{d}^{2} \Pi^{\mathrm{L}} /\left(\mathrm{dq}^{\mathrm{L}}\right)^{2}\right)\left(\mathrm{dq}^{\mathrm{L}} / \mathrm{ds}^{\mathrm{L}}\right)^{2}$ at $\mathrm{d} \Pi{ }^{\mathrm{L}} / \mathrm{dq}^{\mathrm{L}}=0$ and hence $\mathrm{d}^{2} \Pi^{\mathrm{L}} /\left(\mathrm{dq}^{\mathrm{L}}\right)^{2}<0$ at $\mathrm{d} \Pi^{\mathrm{L}} / \mathrm{dq}^{\mathrm{L}}=0$ ensures $\mathrm{d}^{2} \mathrm{~W}^{\mathrm{cL}} /\left(\mathrm{ds}^{\mathrm{L}}\right)^{2}<0$ at $\mathrm{dW}^{\mathrm{cL}} / \mathrm{ds}^{\mathrm{L}}=0$.

To show $\mathrm{d}^{2} \Pi^{\mathrm{L}} /\left(\mathrm{dq}^{\mathrm{L}}\right)^{2}<0$, let $\beta^{\mathrm{c}} \equiv-\mathrm{q}^{\mathrm{L}}\left(\mathrm{dr} / \mathrm{dq}^{\mathrm{L}}\right) / \mathrm{r}$ (analogous to $\beta$ for the Bertrand model), then $\beta^{\mathrm{c}}=$ $-\lambda^{\mathrm{H}} \mathrm{F}^{\prime \prime}\left(\mathrm{q}^{\mathrm{H}}\right) / \Pi_{\mathrm{HH}}^{\mathrm{H}}$ and, as in (A.9), $\mathrm{dr} / \mathrm{dq}^{\mathrm{L}}=-\mathrm{r} \beta^{\mathrm{c}} / \mathrm{q}^{\mathrm{L}}<0, \mathrm{dq}^{\mathrm{cH}} / \mathrm{dq}^{\mathrm{L}}=\mathrm{r}\left(1-\beta^{\mathrm{c}}\right)$ and $1-\beta^{\mathrm{c}}=\mathrm{R}_{\mathrm{HH}}^{\mathrm{H}} / \Pi_{\mathrm{HH}}^{\mathrm{H}}$. From $\Pi^{\mathrm{L}}$ $=\omega(\mathrm{r}) \mathrm{q}^{\mathrm{L}}-\lambda^{\mathrm{L}} \mathrm{F}^{\prime}\left(\mathrm{q}^{\mathrm{L}}\right)$, we obtain $\mathrm{d} \Pi^{\mathrm{L}} / \mathrm{dq}^{\mathrm{L}}=\omega(\mathrm{r})-\mathrm{r} \beta^{\mathrm{c}} \omega^{\prime}(\mathrm{r})-\lambda^{\mathrm{L}} \mathrm{F}^{\prime}\left(\mathrm{q}^{\mathrm{L}}\right)$, and, as in (A.10), it follows that

$$
d^{2} \Pi^{L} /\left(d q^{L}\right)^{2}=-\lambda^{L} F^{\prime \prime}\left(q^{L}\right)+r \beta^{c}\left[r \beta^{c} \omega^{\prime \prime}(r)-\left(1-\beta^{c}\right) \omega^{\prime}(r)\right] / q^{L}-r \omega^{\prime}(r)\left(d \beta^{c} / d q^{L}\right) .
$$

Rearranging (B.11), using $v(r) \equiv 2 \omega(r)-(r)^{2} \omega^{\prime \prime}(r)$ and $\lambda^{\mathrm{L}} \mathrm{F}^{\prime \prime}\left(\mathrm{q}^{\mathrm{L}}\right)=\lambda^{\mathrm{L}} \mathrm{F}^{\prime}\left(\mathrm{q}^{\mathrm{L}}\right) \mathrm{E}^{\mathrm{L}} / \mathrm{q}^{\mathrm{L}}=\left[\omega(\mathrm{r})-\mathrm{r} \beta^{\mathrm{c}} \omega^{\prime}(\mathrm{r})\right] \mathrm{E}^{\mathrm{L}} / \mathrm{q}^{\mathrm{L}}$ at $\mathrm{d} \Pi \mathrm{L} / \mathrm{dq}^{\mathrm{L}}=0$, we then obtain:

$$
d^{2} \Pi^{L} /\left(d q^{L}\right)^{2}=-\left[\left(\beta^{c}\right)^{2} v(r)+\omega(r)\left(E^{L}-2\left(\beta^{c}\right)^{2}\right)-r \omega^{\prime}(r)\left[\beta^{c}\left(E^{L}-\left(1-\beta^{c}\right)\right)-q^{L}\left(d \beta^{c} / d q^{L}\right)\right]\right] / q^{L} .
$$

Letting $A^{0} \equiv\left(\beta^{c}\right)^{2} \mathrm{U}(\mathrm{r})+\left(\omega(\mathrm{r})+\mathrm{r} \omega^{\prime}(r)\right)\left(\mathrm{E}^{\mathrm{L}}-2\left(\beta^{c}\right)^{2}\right)$, it follows using $\mathrm{E}^{\mathrm{L}} \geq 2, \beta^{\mathrm{c}}<1, \mathrm{U}(\mathrm{r}) \geq 0$ from (B.3) and $\omega(r)+r \omega^{\prime}(r)=(r)^{2}(4 r-3) /(4 r-1)^{3}>0$ for $r \geq 1$ that $A^{0}>0$. From $(B .12)$ using $E^{L}-2\left(\beta^{c}\right)^{2}+\beta^{c}\left(E^{L}-\left(1-\beta^{c}\right)\right)=$ $E^{L}+\beta^{c}\left(E^{L}-2\right)+\beta^{c}\left(1-\beta^{c}\right)$ and $\omega^{\prime}(r)<0$, this implies $d^{2} \Pi^{L} /\left(d q^{L}\right)^{2}=-A^{0} / q^{L}+r \omega^{\prime}(r) A^{1} / q^{L}<0$ if

$$
A^{1} \equiv E^{L}+\beta^{c}\left(E^{L}-2\right)+\beta^{c}\left(1-\beta^{c}\right)-q^{L}\left(d \beta^{c} / d q^{L}\right) \geq 0 .
$$


Letting $\xi^{\mathrm{c}} \equiv-\lambda^{\mathrm{H}} \mathrm{F}^{\prime \prime \prime}\left(\mathrm{q}^{\mathrm{H}}\right) / \Pi_{\mathrm{HH}}^{\mathrm{H}}$, it follows as in (A.11) that $\mathrm{d} \beta^{\mathrm{c}} / \mathrm{dq}^{\mathrm{L}}=\mathrm{r}\left(1-\beta^{\mathrm{c}}\right)^{2} \xi^{\mathrm{c}}-\beta^{\mathrm{c}}\left(\mathrm{dR}_{\mathrm{HH}}^{\mathrm{cH}} / \mathrm{dq}^{\mathrm{L}}\right) / \Pi_{\mathrm{HH}}^{\mathrm{H}}$. From $\mathrm{R}_{\mathrm{HH}}^{\mathrm{cH}}=-8(\mathrm{r}-1) /(4 \mathrm{r}-1)^{4} \mathrm{q}^{\mathrm{L}}$, we obtain $\mathrm{dR}_{\mathrm{HH}}^{\mathrm{cH}} / \mathrm{dq}^{\mathrm{L}}=\mathrm{R}_{\mathrm{HHL}}^{\mathrm{H}}+\mathrm{rR}_{\mathrm{HHH}}^{\mathrm{H}}(1-\beta)$ where $\mathrm{R}_{\mathrm{HHL}}^{\mathrm{H}}=-\mathrm{R}_{\mathrm{HH}}^{\mathrm{H}} / \mathrm{q}^{\mathrm{L}}-\mathrm{rR}_{\mathrm{HHH}}^{\mathrm{H}}$ and hence $\mathrm{dR}^{\mathrm{cH}}{ }_{\mathrm{HH}} / \mathrm{dq}^{\mathrm{L}}=-\mathrm{R}_{\mathrm{HH}}^{\mathrm{cH}} / \mathrm{q}^{\mathrm{L}}-\mathrm{r} \beta^{\mathrm{c}} \mathrm{R}_{\mathrm{HHH}}^{\mathrm{cH}}$. Using $\mathrm{R}_{\mathrm{HH}}^{\mathrm{cH}} / \Pi_{\text {HH. }}^{\mathrm{H}}=1-\beta^{\mathrm{c}}$, this implies $\mathrm{d} \beta^{\mathrm{c}} / \mathrm{dq}^{\mathrm{L}}=\left[\beta^{\mathrm{c}}\left(1-\beta^{\mathrm{c}}\right)+(1-\right.$ $\left.\left.\beta^{c}\right)^{2} \mathrm{q}^{\mathrm{H} \xi^{c}}+\mathrm{q}^{\mathrm{H}}\left(\beta^{\mathrm{c}}\right)^{2} \mathrm{R}^{\mathrm{cH}}{ }_{\mathrm{HHH}} / \Pi_{\mathrm{HH}}^{\mathrm{H}}\right] / \mathrm{q}^{\mathrm{L}}$ and, from (B.13), that

$$
\mathrm{A}^{1}=\mathrm{E}^{\mathrm{L}}+\beta^{\mathrm{c}}\left(\mathrm{E}^{\mathrm{L}}-2\right)-\left(1-\beta^{\mathrm{c}}\right)^{2} \mathrm{q}^{\mathrm{H}} \xi^{\mathrm{c}}-\mathrm{q}^{\mathrm{H}}\left(\beta^{\mathrm{c}}\right)^{2} \mathrm{R}_{\mathrm{HHH}}^{\mathrm{cH}} / \Pi_{\mathrm{HH}}^{\mathrm{H}} \cdot
$$

From $\mathrm{R}_{\mathrm{HHH}}^{\mathrm{cH}}=24(4 \mathrm{r}-5) /\left(\mathrm{q}^{\mathrm{L}}\right)^{2}(4 \mathrm{r}-1)^{5}$ using $24(4 \mathrm{r}-5)=96(\mathrm{r}-1)-24, \mathrm{R}_{\mathrm{H}}^{\mathrm{cH}}=(2(\mathrm{r}-1)+1)\left(8(\mathrm{r})^{2}-2 \mathrm{r}+1\right) /(4 \mathrm{r}-1)^{3}$ and $8(\mathrm{r})^{2}-2 \mathrm{r}+1>1$ from $\mathrm{r} \geq 1$, we obtain $\mathrm{R}_{\mathrm{HHH}}^{\mathrm{cH}}>3\left(\mathrm{R}_{\mathrm{HH}}^{\mathrm{cH}}\right)^{2} / \mathrm{R}_{\mathrm{H}}^{\mathrm{cH}}-24 /\left(\mathrm{q}^{\mathrm{L}}\right)^{2}(4 \mathrm{r}-1)^{5}$. Using $\left(\mathrm{R}_{\mathrm{HH}}^{\mathrm{cH}}\right)^{2} /\left(\Pi_{\mathrm{HH}}^{\mathrm{H}}\right)^{2}=(1-$ $\left.\beta^{c}\right)^{2}, R_{H}^{c H}=\lambda^{H} F^{\prime}\left(q^{H}\right)\left(\right.$ from $\left.\Pi_{H}^{H}=0\right)$ and $E^{H}=q^{H} F^{\prime \prime}\left(q^{H}\right) / F^{\prime}\left(q^{H}\right)$, this implies $-q^{H}\left(\beta^{c}\right)^{2} R^{c H}{ }_{H H H} / \Pi_{H H}^{H}>3(1-$ $\left.\beta^{c}\right)^{2} \beta^{c} E^{\mathrm{H}}+24(r)^{2}\left(\beta^{c}\right)^{2} / q^{\mathrm{H}}(4 r-1)^{5} \Pi_{\mathrm{HH}^{\mathrm{H}}}^{\mathrm{H}}$. Hence, letting $\mathrm{M}^{\mathrm{cH}} \equiv \beta^{\mathrm{c}} \mathrm{E}^{\mathrm{H}}-\mathrm{q}^{\mathrm{H}} \xi^{\mathrm{c}}=-\lambda^{\mathrm{H}} \mathrm{q}^{\mathrm{H}} \sigma\left(\mathrm{q}^{\mathrm{H}}\right) / \mathrm{F}^{\prime}\left(\mathrm{q}^{\mathrm{H}}\right) \Pi_{\mathrm{HH}}^{\mathrm{H}} \geq 0$ and $\mathrm{h}(\mathrm{r}) \equiv 2+24(\mathrm{r})^{2} / \mathrm{q}^{\mathrm{H}}(4 \mathrm{r}-1)^{5} \Pi_{\mathrm{HH}}^{\mathrm{H}}$, we obtain

$$
A^{1}>\beta^{c}\left(E^{L}-2\right)+\left(1-\beta^{c}\right)^{2} M^{c H}+2\left(1-\beta^{c}\right)^{2} \beta^{c} E^{H}+E^{L}-2\left(\beta^{c}\right)^{2}+\left(\beta^{c}\right)^{2} h(r) .
$$

Since $E^{L}>2\left(\beta^{c}\right)^{2}\left(\right.$ recall $\left.\beta^{c}<1\right)$, this implies $A^{1}>0$ if $h(r) \geq 0$. Using $R^{c H}=\lambda^{H} F^{\prime}\left(q^{H}\right)$, we have $q^{H} \lambda^{H} F^{\prime \prime}\left(q^{H}\right)$ $=\mathrm{R}_{\mathrm{H}}^{\mathrm{cH}} \mathrm{E}^{\mathrm{H}}$ and since $\Pi_{\mathrm{HH}}^{\mathrm{H}}=\mathrm{R}_{\mathrm{HH}}^{\mathrm{cH}}-\lambda^{\mathrm{H}} \mathrm{F}^{\prime \prime}\left(\mathrm{q}^{\mathrm{H}}\right)<0$ and $\mathrm{E}^{\mathrm{H}} \geq 1$ (from $\mathrm{F}^{\prime \prime \prime}(\mathrm{q}) \geq 0$ ), it follows that

$$
\mathrm{h}(\mathrm{r})=2\left[\mathrm{q}^{\mathrm{H}} \mathrm{R}_{\mathrm{HH}}^{\mathrm{cH}}-\mathrm{R}_{\mathrm{H}}^{\mathrm{cH}}\left(\mathrm{E}^{\mathrm{H}}-1\right)\right] / \mathrm{q}^{\mathrm{H}} \Pi^{\mathrm{H}}{ }_{\mathrm{HH}}-\mathrm{g}(\mathrm{r}) /(4 \mathrm{r}-1)^{5} \mathrm{q}^{\mathrm{H}} \Pi^{\mathrm{H}}{ }_{\mathrm{HH}} \geq 0
$$

for $\mathrm{g}(\mathrm{r}) \equiv 2 \mathrm{R}_{\mathrm{H}}^{\mathrm{cH}}(4 \mathrm{r}-1)^{5}-24(\mathrm{r})^{2} \geq 0$. Using $(4 \mathrm{r}-1)^{2}=(4(\mathrm{r}-1)+3)^{2}=8(\mathrm{r}-1)(2 \mathrm{r}+1)+9$ and $\mathrm{R}_{\mathrm{H}}^{\mathrm{cH}}=\left(16(\mathrm{r})^{3}-12(\mathrm{r})^{2}\right.$ $+4 \mathrm{r}-1) /(4 \mathrm{r}-1)^{3}$ as in (29), it then follows that

$$
\mathrm{g}(\mathrm{r})=16(\mathrm{r}-1)(2 \mathrm{r}+1) \mathrm{R}_{\mathrm{H}}^{\mathrm{cH}}(4 \mathrm{r}-1)^{3}+6\left(48(\mathrm{r})^{3}-40(\mathrm{r})^{2}+12 \mathrm{r}-3\right)>0 \text { for } \mathrm{r} \geq 1 .
$$

Lemma 7: Assume Cournot competition and conditions (1). Sufficient conditions to ensure local concavity offirm H's profit as a Stackelberg leader in quality space or equivalently, local concavity of $W^{c H}$ with respect to $s^{H}$ are $E^{L} \equiv q^{L} F^{\prime \prime}\left(q^{L}\right) / F^{\prime}\left(q^{L}\right) \geq 2$ and $\sigma \equiv\left(F^{\prime \prime}(q)\right)^{2}-F^{\prime}(q) F^{\prime \prime \prime}(q) \geq 0$.

Proof: Since $\mathrm{W}^{\mathrm{cH}}=\Pi^{\mathrm{H}}\left(\mathrm{q}^{\mathrm{L}}, \mathrm{q}^{\mathrm{H}}\right) \equiv \mathrm{R}^{\mathrm{cH}}\left(\mathrm{q}^{\mathrm{L}}, \mathrm{q}^{\mathrm{H}}\right)-\mathrm{F}\left(\mathrm{q}^{\mathrm{H}}\right)$ for $\mathrm{q}^{\mathrm{L}}=\rho^{\mathrm{cL}}\left(\mathrm{q}^{\mathrm{H}}\right)$, it follows as in Lemma 2 that if $\mathrm{d}^{2} \Pi^{\mathrm{H}} /\left(\mathrm{dq}^{\mathrm{H}}\right)^{2}<0$ at $\mathrm{d} \Pi^{\mathrm{H}} / \mathrm{dq}^{\mathrm{H}}=0$, then $\mathrm{d}^{2} \mathrm{~W}^{\mathrm{cH}} /\left(\mathrm{ds}^{\mathrm{H}}\right)^{2}<0$ at $\mathrm{dW}^{\mathrm{cH}} / \mathrm{ds}^{\mathrm{H}}=0$. Letting $\alpha^{\mathrm{c}} \equiv \mathrm{q}^{\mathrm{H}}\left(\mathrm{dr} / \mathrm{dq}^{\mathrm{H}}\right) / \mathrm{r}$ and using $\mathrm{dr} / \mathrm{dq}^{\mathrm{H}}=\left(1-\mathrm{r}\left(\mathrm{dq}^{\mathrm{L}} / \mathrm{dq}^{\mathrm{H}}\right)\right) / \mathrm{q}^{\mathrm{L}}$ and dq ${ }^{\mathrm{cL}} / \mathrm{dq}^{\mathrm{cH}}=\mathrm{R}^{\mathrm{cL}}{ }_{\mathrm{LL}} / \mathrm{r}^{\mathrm{L}}{ }_{\mathrm{LL}}$, we obtain $\alpha^{\mathrm{c}}=-\lambda^{\mathrm{L}} \mathrm{F}^{\prime \prime}\left(\mathrm{q}^{\mathrm{L}}\right) / \Pi^{\mathrm{L}}{ }_{\mathrm{LL}}$. Since $\Pi_{\mathrm{L}}^{\mathrm{L}}=0$ at the Stackelberg equilibrium and $\mathrm{E}^{\mathrm{L}} \geq 2$, this implies $\Pi_{\mathrm{LL}}^{\mathrm{L}}<0$ from Lemma 4(ii) and hence $\alpha^{\mathrm{c}}>0, \mathrm{dr} / \mathrm{dq}^{\mathrm{H}}=\alpha^{\mathrm{c}} / \mathrm{q}^{\mathrm{L}}$ $>0$ and $\mathrm{dq}^{\mathrm{cL}} / \mathrm{dq}^{\mathrm{cH}}=-\left(\alpha^{\mathrm{c}}-1\right) / \mathrm{r}=\mathrm{R}_{\mathrm{LL}}^{\mathrm{cL}} / \mathrm{r}^{\mathrm{L}}{ }_{\mathrm{LL}}<0$. It then follows from $\Pi^{\mathrm{H}}=\psi(\mathrm{r}) \mathrm{q}^{\mathrm{H}}-\lambda^{\mathrm{H}} \mathrm{F}\left(\mathrm{q}^{\mathrm{H}}\right)$ that $\mathrm{d} \Pi^{\mathrm{H}} / \mathrm{dq}^{\mathrm{H}}=$ $\psi(\mathrm{r})+\alpha^{\mathrm{c}} \mathrm{r} \psi^{\prime}(\mathrm{r})-\lambda^{\mathrm{H}} \mathrm{F}^{\prime}\left(\mathrm{q}^{\mathrm{H}}\right)$ and hence 


$$
\mathrm{d}^{2} \Pi^{\mathrm{H}} /\left(\mathrm{dq}^{\mathrm{H}}\right)^{2}=-\lambda^{\mathrm{H}} \mathrm{F}^{\prime \prime}\left(\mathrm{q}^{\mathrm{H}}\right)+\left[\left(\psi^{\prime}(\mathrm{r})+\mathrm{r} \psi^{\prime \prime}(\mathrm{r})\right) \alpha^{\mathrm{c}}+\psi^{\prime}(\mathrm{r})\right]\left(\alpha^{\mathrm{c}} / \mathrm{q}^{\mathrm{L}}\right)+\mathrm{r} \psi^{\prime}(\mathrm{r})\left(\mathrm{d} \alpha^{\mathrm{c}} / \mathrm{dq}^{\mathrm{H}}\right) .
$$

Since $\left(\psi^{\prime}(\mathrm{r})+\mathrm{r} \psi^{\prime \prime}(\mathrm{r})\right) \alpha^{\mathrm{c}}+\psi^{\prime}(\mathrm{r})=\mathrm{q}^{\mathrm{L}} \mathrm{R}_{\mathrm{HH}}^{\mathrm{cH}} \alpha^{\mathrm{c}}-\psi^{\prime}(\mathrm{r})\left(\alpha^{\mathrm{c}}-1\right)<0\left(\right.$ from $\mathrm{R}_{\mathrm{HH}}^{\mathrm{cH}}<0$ and $\left.\alpha^{\mathrm{c}}>1\right)$ and $\psi^{\prime}(\mathrm{r})>0$, it remains to show that $\mathrm{d} \alpha^{\mathrm{c}} / \mathrm{dq}^{\mathrm{H}} \leq 0$. Letting $\xi^{\mathrm{cL}} \equiv-\lambda^{\mathrm{L}} \mathrm{F}^{\prime \prime \prime}\left(\mathrm{q}^{\mathrm{L}}\right) / \Pi^{\mathrm{L}}{ }_{\mathrm{LL}}$, we obtain $\mathrm{d} \alpha^{\mathrm{c}} / \mathrm{dq}^{\mathrm{H}}=\left(\alpha^{\mathrm{c}}-1\right)^{2 \xi^{\mathrm{cL}} / \mathrm{r}-}$ $\alpha^{\mathrm{c}}\left(\mathrm{dR}^{\mathrm{cL}}{ }_{\mathrm{LL}} / \mathrm{dq}^{\mathrm{H}}\right) / \Pi_{\mathrm{LL}}^{\mathrm{L}}$. Using $\mathrm{R}_{\mathrm{LL}}^{\mathrm{cL}}=2(\mathrm{r})^{2}(8 \mathrm{r}+1) /(4 \mathrm{r}-1)^{4} \mathrm{q}^{\mathrm{L}}$ and $\mathrm{dq}^{\mathrm{cL}} / \mathrm{dq}^{\mathrm{cH}}=-\left(\alpha^{\mathrm{c}}-1\right) / \mathrm{r}$, we also have $\mathrm{dR}^{\mathrm{cL}}{ }_{\mathrm{LL}} / \mathrm{dq}^{\mathrm{H}}$ $=\mathrm{R}_{\text {LLH }}^{\mathrm{cL}}-\mathrm{R}_{\text {LLL }}^{\mathrm{cL}}\left(\alpha^{\mathrm{c}}-1\right) / \mathrm{r}$ where $\mathrm{R}_{\text {LLL }}^{\mathrm{cL}}=-\left(\mathrm{R}_{\mathrm{LL}}^{\mathrm{cL}} / \mathrm{q}^{\mathrm{L}}+\mathrm{rR}_{\text {LLH }}^{\mathrm{cL}}\right)$ and hence $\mathrm{dR}_{\text {LL }}^{\mathrm{cL}} / \mathrm{dq}^{\mathrm{H}}=\mathrm{R}_{\mathrm{LL}}^{\mathrm{cL}}\left(\alpha^{\mathrm{c}}-1\right) / \mathrm{q}^{\mathrm{H}}+\alpha^{\mathrm{c}} \mathrm{R}^{\mathrm{cL}}{ }_{\mathrm{LLH}}$ for $\mathrm{R}_{\mathrm{LLH}}^{\mathrm{cL}}=-4 \mathrm{r}(16 \mathrm{r}(\mathrm{r}+1)+1) /\left(\mathrm{q}^{\mathrm{L}}\right)^{2}(4 \mathrm{r}-1)^{5}$. Using $\mathrm{R}_{\mathrm{LL}}^{\mathrm{cL}} / \Pi_{\mathrm{LL}}^{\mathrm{L}}=-\left(\alpha^{\mathrm{c}}-1\right)$, this implies:

$$
\mathrm{d} \alpha^{\mathrm{c}} / \mathrm{dq}^{\mathrm{H}}=-\left(\alpha^{\mathrm{c}}\right)^{2} \mathrm{R}_{\mathrm{LLH}}^{\mathrm{cL}} / \Pi_{\mathrm{LL}}^{\mathrm{L}}+\left(\alpha^{\mathrm{c}}-1\right)^{2}\left(\mathrm{q}^{\mathrm{L}} \xi^{\mathrm{cL}}+\alpha^{\mathrm{c}}\right) / \mathrm{q}^{\mathrm{H}} .
$$

Using $\mathrm{R}_{\mathrm{L}}^{\mathrm{cL}}=(\mathrm{r})^{2}(4 \mathrm{r}+1) /(4 \mathrm{r}-1)^{3}$, we obtain $\mathrm{R}_{\mathrm{LLH}}^{\mathrm{cL}}=-\left[4(\mathrm{r})^{4}(8 \mathrm{r}+1)^{2}(\mathrm{r}+1)+12(\mathrm{r})^{5}\right] /\left(\mathrm{q}^{\mathrm{L}}\right)^{2}(4 \mathrm{r}-1)^{8} \mathrm{rR}_{\mathrm{L}}^{\mathrm{cL}}$ and hence

$$
\mathrm{R}_{\mathrm{LLH}}^{\mathrm{cL}}=-\left(\mathrm{R}_{\mathrm{LL}}^{\mathrm{cL}}\right)^{2}(\mathrm{r}+1) / \mathrm{rR}_{\mathrm{L}}^{\mathrm{cL}}-12(\mathrm{r})^{4} /\left(\mathrm{q}^{\mathrm{L}}\right)^{2}(4 \mathrm{r}-1)^{8} \mathrm{R}_{\mathrm{L}}^{\mathrm{cL}} .
$$

Since $\alpha^{\mathrm{c}}=-\mathrm{E}^{\mathrm{L}} \mathrm{R}_{\mathrm{L}}^{\mathrm{CL}} / \Pi_{\mathrm{L}}^{\mathrm{L}} \mathrm{q}^{\mathrm{L}}\left(\right.$ from $\mathrm{R}_{\mathrm{L}}^{\mathrm{cL}}=\lambda^{\mathrm{L}} \mathrm{F}^{\prime}\left(\mathrm{q}^{\mathrm{L}}\right)$ at $\Pi_{\mathrm{L}}^{\mathrm{L}}=0$ and $\mathrm{E}^{\mathrm{L}}=\mathrm{q}^{\mathrm{L}} \mathrm{F}^{\prime \prime}\left(\mathrm{q}^{\mathrm{L}}\right) / \mathrm{F}^{\prime}\left(\mathrm{q}^{\mathrm{L}}\right)$ ) using $\mathrm{R}_{\mathrm{LL}}^{\mathrm{cL}} / \Pi_{\mathrm{LL}}^{\mathrm{L}}=-$ $\left(\alpha^{\mathrm{c}}-1\right)$ and (B.18), we obtain $\left(\alpha^{\mathrm{c}}\right)^{2} \mathrm{R}_{\mathrm{LLH}}^{\mathrm{cL}} / \Pi_{\mathrm{LL}}^{\mathrm{L}}=\left(\alpha^{\mathrm{c}}-1\right)^{2} \alpha^{\mathrm{c}} \mathrm{E}^{\mathrm{L}}(\mathrm{r}+1) / \mathrm{q}^{\mathrm{H}}-12(\mathrm{r})^{4}\left(\alpha^{\mathrm{c}}\right)^{2} /\left(\mathrm{q}^{\mathrm{L}}\right)^{2}(4 \mathrm{r}-1)^{8} \Pi_{\mathrm{LL}}^{\mathrm{L}} \mathrm{R}_{\mathrm{L}}^{\mathrm{cL}}$. Letting $\mathrm{M}^{\mathrm{cL}} \equiv \alpha^{\mathrm{c}} \mathrm{E}^{\mathrm{L}}-\mathrm{q}^{\mathrm{L}} \xi^{\mathrm{cL}}=-\lambda^{\mathrm{L}} \mathrm{q}^{\mathrm{L}} \sigma\left(\mathrm{q}^{\mathrm{L}}\right) / \mathrm{F}^{\prime}\left(\mathrm{q}^{\mathrm{L}}\right) \Pi^{\mathrm{L}}{ }_{\mathrm{LL}} \geq 0$, it then follows from (B.17), $\mathrm{E}^{\mathrm{L}} \geq 1$ and $\mathrm{r} \geq 1$ that

$$
\mathrm{d} \alpha^{\mathrm{c}} / \mathrm{dq}^{\mathrm{H}}=-\left(\alpha^{\mathrm{c}}-1\right)^{2}\left[\mathrm{M}^{\mathrm{cL}}+\alpha^{\mathrm{c}}\left(\mathrm{E}^{\mathrm{L}} \mathrm{r}-1\right)\right] / \mathrm{q}^{\mathrm{H}}+12(\mathrm{r})^{4}\left(\alpha^{\mathrm{c}}\right)^{2} /\left(\mathrm{q}^{\mathrm{L}}\right)^{2}(4 \mathrm{r}-1)^{8} \Pi_{\mathrm{LL}}^{\mathrm{L}} \mathrm{R}_{\mathrm{L}}^{\mathrm{cL}}<0 \text {. }
$$

Proposition 14. Under Cournot competition, the joint welfare of the two producing countries is maximized by an investment tax in both countries with $s^{c L J}<s^{c L *}<0$ and $s^{c H J}<0<s^{c H *}$.

Proof. Joint welfare is given by $\mathrm{J}^{\mathrm{c}} \equiv \mathrm{W}^{\mathrm{cL}}+\mathrm{W}^{\mathrm{cH} .}$ where $\mathrm{W}^{\mathrm{ci}} \equiv \mathrm{W}^{\mathrm{ci}}\left(\mathrm{s}^{\mathrm{L}}, \mathrm{s}^{\mathrm{H}}\right) \equiv \Pi^{\mathrm{i}}\left(\mathrm{q}^{\mathrm{L}}, \mathrm{q}^{\mathrm{H}}, \lambda^{\mathrm{i}}\right)-\mathrm{s}^{\mathrm{i}} \gamma^{\mathrm{i}} \mathrm{F}\left(\mathrm{q}^{\mathrm{i}}\right)=\mathrm{R}^{\mathrm{ci}}-$ $\gamma^{\mathrm{i}} \mathrm{F}\left(\mathrm{q}^{\mathrm{L}}\right)$ for $\gamma^{\mathrm{L}}=\gamma, \gamma^{\mathrm{H}}=1$ and $\mathrm{i}=\mathrm{L}, \mathrm{H}$. Using $\Pi_{\mathrm{i}}^{\mathrm{i}}=0$ from (28) and $\mathrm{R}_{\mathrm{j}}^{\mathrm{ci}}<0$ from (26), we obtain $\mathrm{dW}^{\mathrm{ci}} / \mathrm{ds}^{\mathrm{j}}=$ $R^{c i}\left(d q^{j} / d s^{j}\right)-s^{j} \gamma^{i} F^{\prime}\left(q^{i}\right)\left(d q^{i} / d s^{j}\right)<0$ for $i \neq j$. At the policies $\left(s^{L *}, s^{H^{*}}\right)$, since $d W^{L} / d s^{L}=d W^{H} / d s^{H}=0$ it follows that $\mathrm{dJ}^{\mathrm{c}} / \mathrm{ds}^{\mathrm{L}}=\mathrm{dW}^{\mathrm{cH}} / \mathrm{ds}^{\mathrm{L}}<0$ and $\mathrm{dJ}^{\mathrm{c}} / \mathrm{ds}^{\mathrm{H}}=\mathrm{dW}^{\mathrm{cL}} / \mathrm{ds}^{\mathrm{H}}<0$ and hence $\mathrm{s}^{\mathrm{LJ}}<\mathrm{s}^{\mathrm{L} *}$ and $\mathrm{s}^{\mathrm{HJ}}<\mathrm{s}^{\mathrm{H} *}$. Following the same steps as in the proof of Proposition 7 and recalling $\mathrm{R}_{\mathrm{j}}^{\mathrm{ci}}<0$ for $\mathrm{i} \neq \mathrm{j}$, we also obtain $\mathrm{s}^{\mathrm{LJ}}=\mathrm{R}_{\mathrm{L}}^{\mathrm{cH}} / \gamma \mathrm{F}^{\prime}\left(\mathrm{q}^{\mathrm{L}}\right)<0$ and $\mathrm{s}^{\mathrm{HJ}}=\mathrm{R}_{\mathrm{H}}^{\mathrm{cL}} / \mathrm{F}^{\prime}\left(\mathrm{q}^{\mathrm{H}}\right)<0$. 


\section{$\underline{\text { References }}$}

Bagwell, K. and R. W. Staiger, 1994, "The sensitivity of strategic and corrective R\&D policy in oligopolistic industries, Journal of International Economics, 36(1-2), 133-50.

Binkley C. S., 1993, Creating a knowledge-based forest sector, Forestry Chronicle, 69(3), 294-299.

Bond, E., 1988, Optimal commercial policy with quality-differentiated products, Journal of International Economics, 25, 271-290.

Brander, J. A. and B. J. Spencer, 1985, Export subsidies and market share rivalry, Journal of International Economics, 18, 83-100.

Das, S. P. and S. Donnenfeld, 1987, Trade policy and its impact on quality of imports: A welfare analysis, Journal of International Economics, 23, 77-95.

Das, S. P. and S. Donnenfeld, 1989, Oligopolistic competition and international trade: quantity and quality restrictions, Journal of International Economics, 27, 299-318.

De Meza, D., 1986, Export subsidies and high productivity: cause or effect?, Canadian Journal of Economics 19, 347-350.

Eaton, J. and G. M. Grossman, 1986, Optimal trade and industrial policy under oligopoly, Quarterly Journal of Economics, 101, 383-406.

Feenstra, R.C., 1988, Quality changes under trade restrictions: theory and evidence, Quarterly Journal of Economics 102, 131-146.

Gabszewicz, J. J. and J. F. Thisse, 1979, Price competition, quality and income disparities, Journal of Economic Theory, 20, 340-359.

Herguera, I., P. Kujal and E. Petrakis, 1999, Quantity restrictions and endogenous quality choice, International Journal of Industrial Organization, forthcoming.

Inglehart R. F., 1990, Culture shifts in advanced industrial society, Princeton, N.J.: Princeton Univ. Press.

Krishna, K., 1987, Tariffs vs. quotas with endogenous quality, Journal of International Economics, 23, 96-112.

Motta, Massimo, 1993, "Endogenous quality choice: price vs. quantity competition”, Journal of Industrial Economics XLI, 113 - 131. 
Neary, J. P., 1994, Cost asymmetries in international subsidy games: Should governments help winners or losers?, Journal of International Economics, 37, 197-218.

Ries, J.C., 1993, “Voluntary export restraints, profits, and quality adjustment”, Canadian Journal of Economics, XXVI, 688-706.

Ronnen, U., 1991, Minimum quality standards, fixed costs and competition, Rand Journal of Economics 22, 490-504.

Shaked, A. and J. Sutton, 1982, Relaxing price competition through product differentiation, Review of Economic Studies, 46, 1-13.

Shaked, A. and J. Sutton, 1983, Natural Oligopolies, Econometrica, 51, 1469-83.

Spencer, B. and J. Brander, 1983, International R \& D rivalry and industrial strategy, Review of Economic Studies, 50, 707-722.

Tirole, J., 1988, The theory of industrial organization, Cambridge, Mass., MIT Press.

Ursacki T. and I. Vertinsky, 1994, Long-term changes in Korea's international trade and investment, Pacific Affairs, 67 (3), 385-409.

Wade, R., 1990, Governing the market: economic theory and the role of government in East Asian industrialization, Princeton, N.J.: Princeton Univ. Press.

Wilson B., G. C. van Kooten, I Vertinsky and L. Arthur, 1998 eds., Forest Policy: International Case Studies, CABI Publishing, Oxford. 